\title{
Geology and Fluorspar Deposits, Northgate District, Colorado
}

By THOMAS A. STEVEN

CONTRIBUTIONS TO ECONOMIC GEOLOGY

GEOLOGICAL S URVEY B ULLETIN $1082-\mathrm{F}$

Prepared in cooperation with the Colorado State Geological Survey Board and the Colorado Metal Mining Fund Board

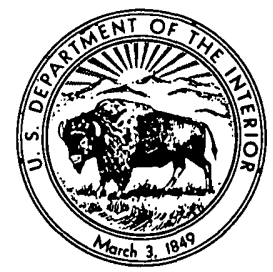




\section{UNITED STATES DEPARTMENT OF THE INTERIOR}

FRED A. SEATON, Secretary

\section{GEOLOGICAL SURVEY}

Thomas B. Nolan, Director 


\section{CONTENTS}

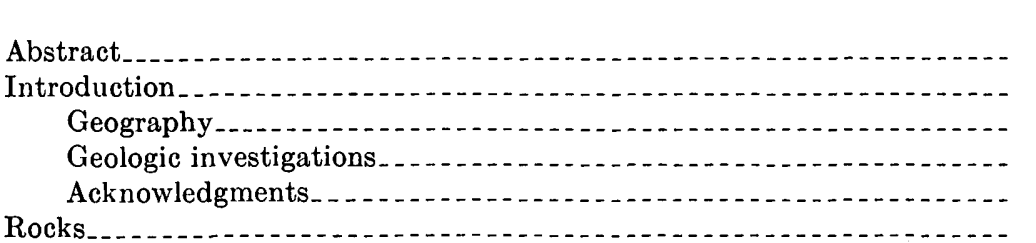

Precambrian rocks

Gneiss complex

Dacite porphyry

Intrusive quartz monzonite

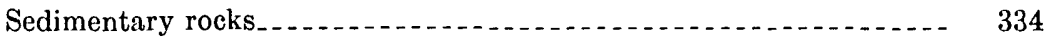

Permian rocks

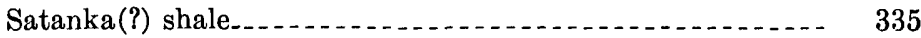

Forelle(?) limestone._.

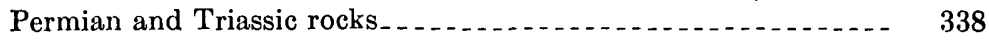

Chugwater formation .

Jurassic rocks . . . . . .

Sundance formation

Morrison formation ................. 342

Cretaceous rocks.

Dakota group as used by Lee (1927) $\ldots \ldots \ldots 3$

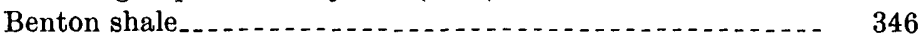

Niobrara formation

Pierre shale

Tertiary rocks................ 350

White River formation.............. 350

North Park formation

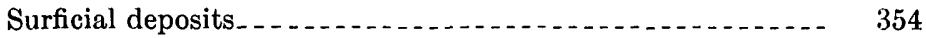

Structure

Structural features of the gneiss complex.

Structural features of the intrusive rocks_.

Dacite porphyry dikes...

Structures of the intrusive quartz monzonite . . . . . . . . . . . . . 355

Structures related to the Laramide orogeny . .

Medicine Bow arch.

North Park basin

Sentinal Mountain-Dean Peak faulted anticline $\ldots \ldots \ldots$

Syncline east of Sentinal Mountain . . . . . 363

Structures along the front of the Medicine Bow Mountains. ... 363

Folds west of the Sentinal Mountain-Dean Peak anticline _... 366

Faults south and southwest of Sentinal Mountain _._.

Independence Mountain fault........

Faults of probable Laramide age $\ldots$ 
Structure-Continued $\quad$ Page

Post-Laramide structures................................. 371

Possible late Oligocene or Miocene deformation _._.

Pliocene warping . .

Late Tertiary(?) faults _...

Fluorspar-Gero-Penber fault zone._... 376

Fluorine-Camp Creek fault zone..._._.

Minor faults of late Tertiary(?) age...

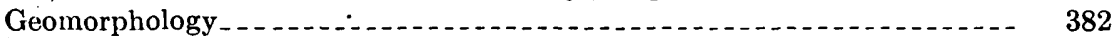

Pre-White River erosion surface...

Pre-North Park erosion surface

Medicine Bow surface

Pleistocene rejuvenation

Mineral deposits............... 386

Copper deposits.

Vermiculite deposits.

Fluorspar deposits

History

Fluorspar of Laramide(?) age..._._. 395

Fluorspar of late Tertiary(?) age

Vein material on the Fluorspar-Gero-Penber vein zone..... 397

Vein material on the Fluorine-Camp Creek vein zone..... 400

Structural control................................... 401

Vertical range of fluorspar deposits._.

Environment of deposition

Depth of deposition

Composition of the mineralizing fluid.............. 408

Temperature of deposition

Conditions of deposition...... 411

Source of fluorine...

Corollary hypothesis......... 414

Suggestions for prospecting

References cited

Index

\section{ILLUSTRATIONS}

[Plates 12-15 in pocket]

Pliate 12. Geologic map and sections of the Northgate district.

13. Geologic map of the 200-foot level and composite map of the Fluorspar mine.

14. Geologic map of the Fluorspar-Gero-Penber vein zone.

15. Geologic map of the Fluorine-Camp Creek vein zone.

16. Rounded pebbles from the Fluorspar-Gero-Penber vein zone . . . . . . . . Facing

17. Stalactitic growth from the Springer pit, Fluorspar-GeroPenber vein zone...... Facing 
Figure 33. Index map showing the location of the Northgate district...-

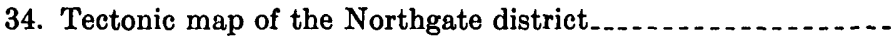

35. Dip measurements of beds and crossbeds....

36. Geologic map of the lower adit, Kings Canyon mine

37. Sketch map of an altered ultramafic mass in sec. $36, \mathrm{~T} .12 \mathrm{~N}$., R. $80 \mathrm{~W}$

38. Sketch of the wall of a prospect pit in the south-central part of sec. 26, T. 12 N., R. $80 \mathrm{~W}$

39. Quaintance vermiculite prospect

40. Geologic map of the Gero workings and Penber surface workings .

41. Geologic map of the lower level, Penber mine

\section{TABLES}

TABLE 1. Stratigraphic sequence in the Northgate district and adjacent

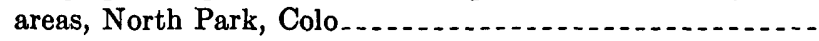

2. Data from fluid inclusions in fluorite from the Northgate

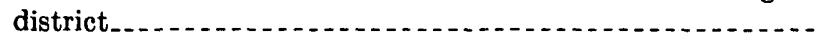





\title{
CONTRIBUTIONS TO ECONOMIC GEOLOGY
}

\section{GEOLOGY AND FLUORSPAR DEPOSITS OF THE NORTHGATE DISTRICT, GOLORADO}

\author{
By Thomas A. Steven
}

\begin{abstract}
The fluorspar deposits in the Northgate district, Jackson County, Colo., are among the largest in Western United States. The mines were operated intermittently during the 1920's and again during World War II, but production during these early periods of operation was not large. Mining was begun on a larger scale in 1951, and the district has assumed a prominent position among the fluorspar producers in the United States.

Within the Northgate district, Precambrian metamorphic and igneous rocks crop out largely in the Medicine Bow Mountains, and later sedimentary rocks underlie North Park and fill old stream valleys in the mountains.

The metamorphic rocks constitute a gneiss complex that formed under progressively changing conditions of regional metamorphism. They consist principally of hornblende-plagioclase gneiss (hornblende gneiss), quartz monzonite gneiss, pegmatite, biotite-garnet-quartz-plagioclase gneiss (biotite-garnet gneiss), hornblende-biotite-quartz-plagioclase gneiss (hornblende-biotite gneiss) and mylonite gneiss.

The igneous rocks comprise some local fine-grained dacite porphyry dikes near the west margin of the district, and a quartz monzonitic stock and associated dikes in the central and eastern parts of the district.

The sedimentary rocks in the district range in age from Permian to Recent. Folded Permian and Mesozoic rocks underlie the basin of North Park, and consist in sequence from oldest to youngest, of Satanka(?) shale (0-50 feet of brick-red shale) and Forelle(?) limestone (8-15 feet of pink to light-gray laminated limestone) of Permian age, Chugwater formation of Permian and Triassic age (690 feet of red silty shale and sandstone), Sundance formation of Late Jurassic age (145 feet of sandstone containing some shale and limestone), Morrison formation of Late Jurassic age (445 feet of variegated shale and minor sandstone and limestone), Dakota group as used by Lee (1927), now considered to be of Early Cretaceous age in this area (200-320 feet of pebbly sandstone, sandstone, and shale), Benton shale of Early and Late Cretaceous age (665 feet of dark-gray thin-bedded shale), Niobrara formation of Late Cretaceous age (865 feet of yellow to gray limy siltstone and shale), and Pierre shale of Late Cretaceous age (more than 60 feet of dark-gray fissile shale). Unconformities separate the Chugwater and Sundance formations, and the Morrison formation and the Dakota group.
\end{abstract}


Nonmarine strata of the White River formation of Oligocene age and the North Park formation of Miocene and Pliocene(?) age fill Tertiary valleys cut in the Precambrian rocks of the mountain areas, and Quaternary terrace gravel, alluvium, and dune sand mantle much of the floor of North Park.

The main outlines of the modern Rocky Mountains formed during the Laramide orogeny in late Mesozoic and early Tertiary time. Most of the Laramide structures that can be recognized in the Northgate district involve the sedimentary rocks underlying North Park which are folded into northwest-trending anticlines and synclines. The folds are open and in most the beds dip $60^{\circ}$ or less. Yet many anticlines are cut by reverse faults of widely different trends and directions of offset. Transverse faults offset some of the folds, and the character of folding commonly is markedly different on opposing sides of these faults. The North Park basin is cut off on the north by the east-trending Independence Mountain fault, a north-dipping reverse fault along which hard Precambrian rocks have been thrust up across the trend of the earlier Laramide structures. The North Park basin is still a major structure where it is interrupted by the Independence Mountain fault, and the original basin must have extended much farther north.

Disrupted gradients at the base of pre-White River valleys suggest that the Northgate district and adjacent areas may have been deformed in middle Tertiary time, but the evidence is not conclusive. A more definite period of deformation took place in Pliocene time following deposition of the North Park formation. North Park strata in south-central North Park were folded into a northwest-trending syncline, and the central part of the Northgate district probably was warped up along a north- or northwestward-trending axis.

Four north- to northwestward-trending faults cut the Precambrian rocks and White River formation on Pinkham Mountain and the area to the southeast. Similar faults $2 \frac{1}{2}$ and 15 miles west of the Northgate district cut rocks of the North Park formation, and all probably formed during the Pliocene period of deformation. The known commercial fluorspar deposits are localized along the two larger faults of the Northgate district, and they have been studied in detail.

The White River formation in early Oligocene time covered a hilly terrain drained by southward-flowing streams. By late Miocene, the northward-flowing streams had cut to about the same levels reached by the pre-White River streams and had partly exhumed and modified the older terrain. During late Miocene and early Pliocene(?) time, the Northgate area was buried beneath the clays, sands, and gravels of the North Park formation. Subsequent erosion removed the higher part of the North Park formation, cut a surface of low relief across the exhumed Precambrian rocks, and removed all topographic evidence of the Pliocene period of deformation. The present courses of the major streams were superimposed across the buried terrains during this period of erosion. Rejuvenation during middle Pleistocene caused all major streams to become incised in sharp canyons.

Copper minerals occur in small concentrations in some of the pegmatite masses in the gneiss complex. The copper-rich masses rarely exceed a ferv feet in diameter and constitute only a small part of the associated pegmatite body.

Vermiculite is exposed in prospect pits and mine workings along the west margin of the Northgate district. All the vermiculite that was seen is associated with small masses of hornblendite, massive chlorite, or serpentinite where these masses are near or are cut by pegmatite bodies. Some of the deposits 
may be potential producers of commercial-grade vermiculite, but most are small and erratic in shape or grade.

Fluorspar is the main mineral commodity that has been produced from the Northgate district. It was deposited during two distinct periods of mineralization, but only the younger deposits have been productive.

Small bodies of silicified breccia containing minor coarsely crystalline fluorite occur along the Independence Mountain fault, and in a few places along other Laramide faults. The fluorspar is an integral part of the fault breccia and apparently was deposited while the enclosing fault was still active.

The largest deposits of fluorspar in the Northgate district occur along the late Tertiary (?) faults on Pinkham Mountain. The fluorspar consists typically of botryoidal layers that formed as successive encrustations along open fractures, or as finely granular aggregates replacing and cementing fault gouge and White River formation. Many incompletely filled cavities, called water courses, still exist. Fluorite is the principal vein material ; fragments of country rock constitute the chief impurity although finely granular quartz or chalcedony is common locally. Soft powdery manganese oxide coats many fractures and in places is associated with a fine white clay.

Fluorspar was deposited in or adjacent to open spaces along the late Tertiary (?) faults. Fractures in hard granitic rocks tended to remain open after faulting and were the favored sites for fluorspar deposition; fractures in the less competent hornblende and hornblende-biotite gneiss and schist generally were tight and little fluorspar was deposited. The White River rocks, although soft, were permeable and were widely impregnated or replaced by fluorspar.

Both of the main vein zones are along faults that have predominant rightlateral strike-slip displacement. As they theoretically should be, the rein zones are narrower and contain less fluorspar where the containing fault is deflected to the left than where the fault is deflected to the right and the fractures remained open.

The crustifled, vuggy structure of the fluorspar and the common association with chalcedony or finely granular quartz suggest deposition in a very shallow environment, but no direct evidence bearing on the depth at which the fluorspar formed was seen. Fluorspar was deposited throughout a vertical range of 600 feet or more on each of the main vein zones, and for a vertical range of 1,050 feet for the district as a whole. None of the deposits had been bottomed at the time this report was prepared.

Exploration at depth beneath known ore bodies is favorable for developing large tonnages of fluorspar. The best possibilities for flnding new ore bodies near the surface are along the northwestern and southeastern parts of the Fluorine-Camp Creek vein zone where large bodies of granitic rocks are intersected by the fault. These areas are generally mantled by a thick overburden, and have been inadequately tested so far.

\section{INTRODUCTION}

The fluorspar deposits in the Northgate district, Colorado, are among the largest in Western United States, and eventual production probably will be in terms of several million tons of fluorspar concentrates. High transportation costs and a general shortage of trained labor retarded early development of the district, and the mines were able to compete with those in more favorably located areas only during such boom periods as the 1920's and during World War II. In 1951, 
however, mining was begun on a larger scale, and the district has assumed a prominent position among the fluorspar producers in the United States.

A great diversity of rock types is exposed in a small area centering on the fluorspar deposits, and a study of the district has discovered a wide range of geologic problems. The data and interpretations resulting from investigations of the Precambrian rocks and of the Cenozoic geomorphic history are reported in detail in separate reports (Steven, 1956, 1957a), and are summarized only briefly in the present report. Emphasis here is given to the general geology of the area and to the mineral deposits.

The geologic studies in the Northgate district are part of a longrange program for the study of the mineral-producing areas in Colorado that is being done by the U.S. Geological Survey in cooperation with the Colorado State Geological Survey Board and the Colorado Metal Mining Fund Board.

\section{GEOGRAPHY}

The Northgate district, in Jackson County, Colo., is on the western flank of the Medicine Bow Mountains, and includes the northeast corner of the North Park intermontane basin (fig. 33). The area

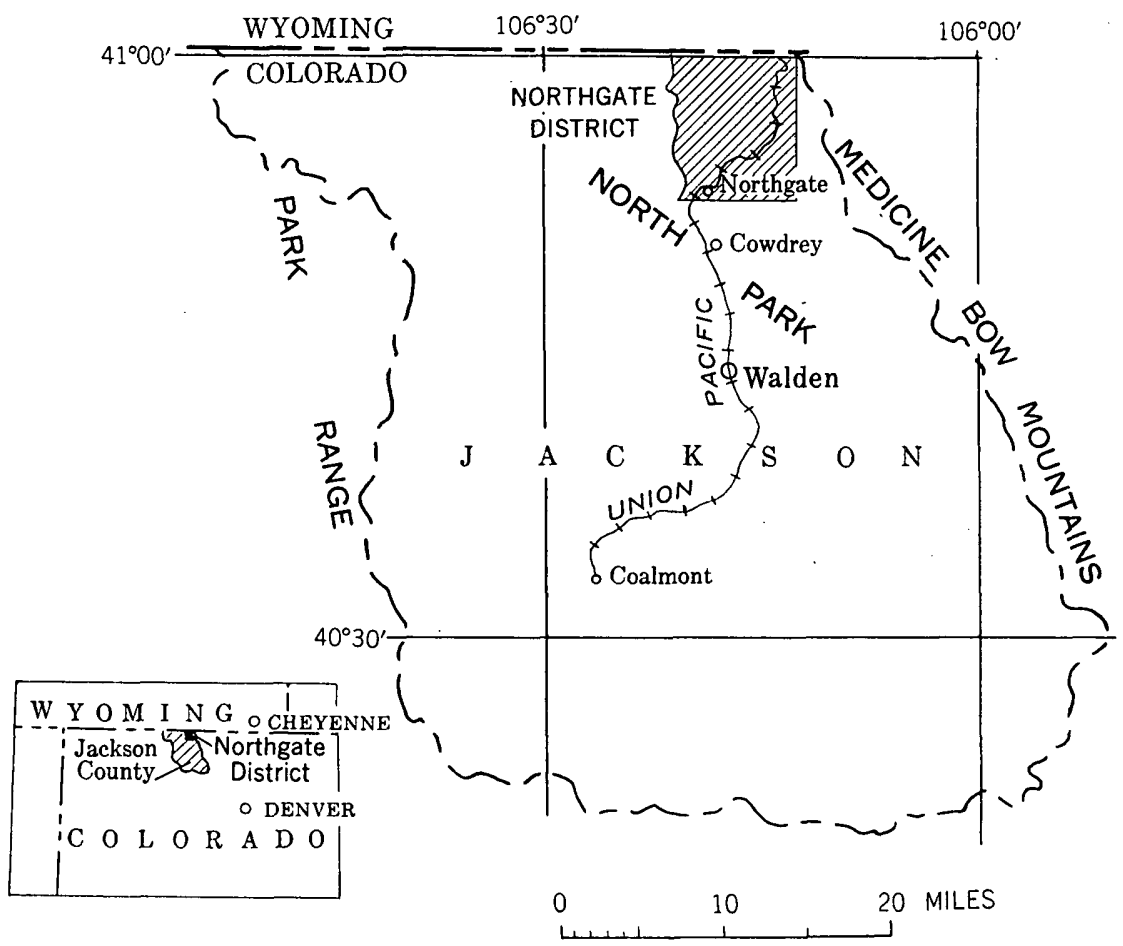

Figdre 33.-Index map showing the location of the Northgate district, Colorado. 
covered in detail by this report is bounded on the north by the Colorado-Wyoming State line, on the west by the North Platte River, on the south by lat $40^{\circ} 52^{\prime} 30^{\prime \prime}$, and on the east by the range line between R. $78 \mathrm{~W}$. and R. $79 \mathrm{~W}$.

The Northgate district and adjacent areas is sparsely populated and has only a few improved roads. The nearest town is Cowdrey, a small settlement about 1 mile south of the district along State Highway 125; Walden, the seat of Jackson County, is 9 miles farther south along the same highway. State Highway 127 (Wyoming State Highway 230) connects with Laramie, Wyo., about 50 miles to the northeast, and State Highway 125 (Wyoming State Highway 230) connects with Encampment, Wyo., about 30 miles to the northwest. Local access is gained by means of U.S. Forest Service, ranch, and logging roads. Of these, only the road across Pinkham Mountain is graveled; many of the other roads are passable only with difficulty. A Union Pacific Railroad branch line connects Coalmont, in the southern part of North Park, with Laramie, Wyo., and passes through the south-central and eastern parts of the Northgate district.

Claim patent descriptions list the fluorspar deposits as occurring in the Copper Ridge mining district, a name formerly applied to a large, indefinite area in northern Colorado and southern Wyoming. This name has been dropped from local usage, and the more restricted area in the vicinity of the fluorspar deposits now is called the Northgate district, after the shipping point of Northgate on the Union Pacific Railroad.

North Park is a broad topographic and structural basin between the Medicine Bow Mountains and the Park Range. The altitude along the North Platte River in the northern part of North Park and near the west edge of the Northgate district is about 7,840 feet; adjacent to the bordering Medicine Bow Mountains in the Northgate district, the floor of the park ranges in altitude from 8,400 to 8,600 feet. The larger streams in North Park all follow meandering courses through broad flood plains, which are now largely occupied by hay meadows belonging to the many large ranches in the area. Stream terraces flank some of the flood plains, but most of the interfluves consist of low, rolling topography cut on folded sedimentary rocks. Where irrigation is feasible, the terraces have been converted into hay meadows, but for the most part the floor of North Park away from the flood plains is covered by sagebrush and grass and is used for grazing only.

North Park and the adjacent mountain slopes form the watershed of the North Platte River, which flows northward through the broad basin of North Park (pl. 12). After leaving North Park the river plunges through a narrow gorge along the west margin of the North- 
gate district, and flows northward into Wyoming along the flank of the Medicine Bow Mountains. The divide between North Platte River and Laramie River drainage basins is along the crest of the Medicine Bow Mountains near the east margin of the Northgate district, and no major tributary crosses the district. Drainage here is by means of many minor westward-flowing streams, only three of which are large enough to maintain permanent flow (pl. 12). The southeastern part of the Northgate district is drained by Government Creek, a small stream with only a limited watershed within the mountains. It flows southwestward across North Park and empties into the Canadian River near Cowdrey. Pinkham Creek, the largest tributary in the Northgate district, heads along the crest of the Medicine Bow Mountains east of the district; it enters the northeast corner of North Park through Kings Canyon and flows westward near the north edge of the park, entering the North Platte River just south of where the river leaves North Park. Camp Creek heads in the northeastern part of the Northgate district and flows generally southwestward across the low upland that comprises the Medicine Bow Mountains in this area. Camp Creek enters the North Platte River as a markedly barbed tributary near where State Highway 125 crosses the river.

Because of the altitude, North Park and the surrounding mountains have long, cold winters and short, cool summers. In the Northgate district several feet of snow generally blankets the ground in the winter, and subzero weather is common. Although the heaviest snowfall occurs between November and May, very commonly less than 3 months separates the last snowstorm in the spring and the first snowstorm in the fall. Summer days generally are fair, although thunder showers occur frequently during July and August.

Cattle ranching, logging, and petroleum production are the chief industries in the North Park region; mining has been only a minor activity, the significant production being in coal from near Coalmont and fluorspar from the Northgate district. Oil has been produced from the McCallum anticline field northeast of. Walden for many years, and several petroleum companies were actively exploring the North Park area when this report was being prepared. Gold, copper, and vermiculite prospects are found near the north end of North Park, but at the time fieldwork for this report was done these prospects had not been operated successfully.

\section{GEOLOGIC INVESTIGATIONS}

The broader features of North Park and the surrounding mountains were studied briefly by Arnold Hague (Hague and Emmons, 1877 , p. 94-129) as part of the general reconnaissance made between 
1867 and 1873 by the U.S. Geological exploration of the 40th parallel. Beekly (1915) described the coal resources and general geology of North Park, and although the work was based on but one season of fieldwork and was done without an adequate base map, the general structural and stratigraphic features of the area were fairly well delineated. Miller (1934) made a more detailed study of the stratigraphy and structure of the McCallum anticlines, about 9 miles east of Walden, while investigating the petroleum and carbon dioxide occurring there. The Guidebook, Eighth Annual Field Conference, Laramie Basin, Wyo., and North Park, Colo. (Wyoming Geol. Assoc., 1953) and the Guidebook to the Geology of North and Middle Parks basins, Colorado (Rocky Mountain Assoc. Geologists, 1957), each presented several papers on the general area, and those with direct bearing on the geology of the Northgate district will be referred to at appropriate places in this report.

The fluorspar deposits in the Northgate district have been described briefly by Ladoo (1923, 1927), Burchard (1933), and Cox (1945). Goldring (1942) noted an occurrence of ilsemannite at one of the deposits.

The present investigation began in 1943 as part of the U.S. Geological Survey's wartime investigations of strategic and critical minerals, when D. C. Cox, assisted by J. O. Fisher and J. W. Odell, made a preliminary study of the larger fluorspar deposits in the district. A more detailed study of the vein zones was made in 1944 and 1945 by D. C. Cox and W. E. Benson, assisted by D. M. Henderson, while the U.S. Geological Survey was cooperating in an exploration program with the U.S. Bureau of Mines. The writer made two brief visits to the area in the winter of 1945-46, near the end of the exploration program. The Bureau of Mines discontinued fieldwork in March 1946, and the results of their work were published in 1947 (Warne, 1947). Geologic maps and a brief preliminary report on this early phase of the work were published by the Geological Survey in 1948 (Cox and others, 1948).

The writer, assisted at different times by R. B. Johnson, A. L. Bush, and G. W. Weir, spent approximately 11 months during the field seasons of 1946, 1947, and 1948 in mapping the regional geology of the district and in reviewing the detailed geology of the fluorspar deposits. The general geology of the district has been summarized in two preliminary reports (Steven, 1953, 1954), and the petrology of the Precambrian crystalline rocks and the Cenozoic geomorphic history have been discussed in detail in separate reports (Steven, 1956, 1957a). A brief paper on the Sentinal Mountain-Dean Peak anticline was published in 1957 (Steven, 1957b). 


\section{ACKNOWLEDGMENTS}

The investigations of the Geological Survey were facilitated by the cooperation of the mining companies in the Northgate district. The staffs of Kramer Mines, Inc., Western Fluorspar Corp., Colorado Fluorspar Corp., Ozark-Mahoning Co., and the Aluminum Company of America provided much information critical to a study of the fluorspar deposits.

The writer was assisted in his study of the Tertiary geologic history of the area by field conferences and correspondence with Professors P. O. McGrew and S. H. Knight of the University of Wyoming.

Fieldwork also was facilitated by the cooperation of local residents and property owners, and Mr. M. P. Cloonan and Mr. C. E. Mitchell deserve special mention for their friendly assistance. The fluorspar mines were visited several times after they were reopened by the Ozark-Mahoning Co. in 1951, and the cordial cooperation given by their field staff, headed by Mr. R. K. Wisco, general superintendent, and Mr. F. H. Hansen, mining engineer, is greatly appreciated.

\section{ROCKS}

The rocks in the Northgate district can be divided geologically and geographically into two general groups: the Precambrian metamorphic and igneous rocks of the mountain areas, and the later sedimentary rocks underlying North Park and filling old stream valleys in the mountains ( $\mathrm{pl}$. 12). These two groups contrast so strongly and are separated in age by such a tremendous span of time that discussions of each have little in common. For this reason, the details of petrology and interpretations of origin of the Precambrian rocks have been given in a separate report (Steven, 1957a), and are summarized only briefly here. The sedimentary rocks, on the other hand, are now discussed fully and all pertinent data collected during fieldwork are recorded.

\section{PRECAMBRIAN ROCKS}

The Precambrian rocks in the Northgate district consist of a gneiss complex invaded by a quartz monzonite stock. A few dacite porphyry dikes cut the gneiss complex and are older than the intrusive stock. According to interpretations detailed in an earlier report (Steven, $1957 \mathrm{a})$, the rocks in the gneiss complex were formed under progressively changing conditions of regional metamorphism, and record successive dynamothermal metamorphism, alkali and silica metasomatism concurrent with dynamic metamorphism, and local rheomorphism. The quartz monzonite stock, on the other hand, was emplaced into a more shallow environment by magmatic stoping. Many of the inter- 
nal textures are interpreted to have resulted from deuteric alteration by late magmatic solutions.

\section{GNEISS COMPLEX}

An originally layered series of rocks was converted by dynamothermal metamorphism into a hornblende-plagioclase gneiss (hornblende gneiss) (Steven, 1957a, p. 338-342). This rock is generally a dark, medium-grained gneiss that crops out in blocky layers several inches to several feet thick. Most hornblende gneiss consists chiefly of hornblende and intermediate plagioclase $\left(\mathrm{An}_{30}\right.$ to $\left.\mathrm{An}_{55}\right)$, which commonly occur in about equal amounts. Some layers differ greatly in composition and locally either hornblende or plagioclase predominate. Quartz, biotite, and augite are local minor constituents.

Small ultramafic pods, consisting largely of hornblende, chlorite, or serpentine, occur locally within the hornblende gneiss. A few serpentine-bearing bodies contain small residual aggregates of olivine and tremolite. The rims of many of these ultramafic bodies contain irregular bodies of vermiculite, which will be discussed in more detail in the section on mineral deposits.

Metasomatism following dynamothermal metamorphism converted large volumes of the hornblende gneiss into quartz monzonite gneiss, pegmatite, and biotite-garnet-quartz-plagioclase gneiss (biotite-garnet gneiss) (Steven, 1957a, p. 342-353). The quartz monzonite gneiss forms extremely complex bodies that range from a few feet in diameter to rudely tabular masses with dimensions of several miles. These larger bodies are most abundant in the northern and southern parts of the district. The quartz monzonite gneiss generally is a mediumgrained pink rock composed principally of albite or oligoclase, microcline, and quartz, and minor biotite and chlorite. In outcrop the rock appears distinctly banded, as it consists of layers which contrast to different degrees in texture or mineral composition. The layers range from less than an inch to several feet in thickness, and are massive to well foliated.

Microcline-plagioclase-quartz pegmatite is abundant locally, particularly in the central part of the Northgate district, and forms irregular bodies that range from a few inches in diameter to masses more than 2 miles in length and 2,000 feet in width. Many smaller bodies grade imperceptibly from pegmatite to quartz monzonite gneiss. Most of the pegmatite is a simple quartz-feldspar aggregate containing local subordinate muscovite, biotite, garnet, or magnetite.

Irregular masses of biotite-garnet gneiss occur throughout the central part of the Northgate district where they are closely associated with pegmatite. The chief constituents of this rock are biotite, garnet, quartz, and plagioclase $\left(\mathrm{An}_{28-35}\right)$, but the relative proportions 
of these vary widely. Biotite-garnet gneiss grades from hornblende gneiss containing minor quartz, biotite, and garnet, to coarsely porphyroblastic augen gneiss, banded lit-par-lit gneiss, and quartzplagioclase-garnet pegmatite. Local variations in texture and composition are pronounced.

Shearing concurrent with metasomatism produced a gradational series of rocks that ranges in structure from weakly foliated hornblende-biotite-quartz-plagioclase gneiss (hornblende-biotite gneiss), through strongly foliated hornblende-biotite gneiss, to mylonite gneiss (Steven, 1957a, p. 353-357). Hornblende-biotite gneiss forms discontinuous tabular masses complexly interlayered with normal hornblende gneiss and other rocks of the gneiss complex in a belt about 2 miles wide which trends northeast from Pinkham Mountain. Where the original hornblende gneiss was only weakly sheared, biotite and quartz are minor constituents and the rock closely resembles hornblende gneiss. With an increasing degree of granulation, biotite and quartz become more abundant and the rock becomes finer grained and more closely foliated. Where granulation was nearly complete, the rocks grade into dense, uniform to banded gray mylonite gneisses. Most hornblende-biotite gneiss, however, is a medium-grained schistose rock in which the main constituents can all be recognized easily with a hand lens.

Mylonite gneiss is most common along Pinkham Creek adjacent to the belt containing abundant hornblende-biotite gneiss (Steven, 1957a, p. 354-357). The rocks vary widely in texture and composition, depending on the original material, the intensity of granulation, the degree of recrystallization and the amount of subsequent metasomatic alteration. Mylonite gneiss derived from hornblende gneiss is generally a fine-grained, closely foliated, micaceous gray rock that commonly shows abundant thin, crenulated, feldspathic streaks and layers. Quartz monzonite gneiss and pegmatite, where thoroughly granulated, were reduced to a very fine grained, streaked pink and gray rock containing scattered rounded to lozenge-shaped feldspar augen. Many masses of mylonite gneiss contain well-formed feldspar augen or were replaced in part subsequent to cataclasis by small pegmatite or quartz monzonite gneiss bodies, indicating a general contemporaneity of regional metasomatism and local dynamic metamorphism.

Some of the rock in the larger masses of quartz monzonite gneiss became mobile or rheomorphic after metasomatic transformation (Steven, 1957a, p. 357-364). Relations are clearest near the northwest corner of the district, where a conical mass of quartz monzonite gneiss about $11 / 2$ miles long and $3 / 4$ mile wide invaded the adjacent rocks. The adjacent layered rocks were highly deformed, and many 
details of movement can be deciphered. Similar highly deformed rocks occur near the southeast corner of the district, and apparently are marginal to another mass of formerly mobile quartz monzonite gneiss to the east. The rheomorphic quartz monzonite gneiss generally is in layers which range from a few feet to a few tens of feet in thickness. Adjacent layers may be closely similar or may contrast markedly in grain size, texture, or mineral composition. Most of the rock is a medium-grained aplitic aggregate of quartz and feldspar, containing a little biotite. A few discontinuous bodies of somewhat recrystallized hornblende gneiss are interlayered with the aplitic rock, and locally highly contorted layers with textures characteristic of normal quartz monzonite gneiss can be recognized. Irregular pegmatitic masses occur throughout the rheomorphic quartz monzonite gneiss; these masses obliterate all other textures.

\section{DACITE PORPHYRY}

A very fine grained, medium- to dark-gray rock forms several northward-trending dikes near the lower end of Camp Creek (Steven, 1957a, p. 364-365). The largest of these dikes is about 3,000 feet long and about 5 feet in maximum thickness; the other related dikes are much smaller. The dikes cut the rocks of the gneiss complex and show no sign of being metamorphosed. Short segments of the dikes are also found in xenoliths in the intrusive quartz monzonite stock. The dikes are thus intermediate in age between the rocks in the gneiss complex and later intrusive stock, and they may be unrelated to either.

The dacite porphyry typically is composed of 40 to 50 percent andesine, 15 to 20 percent biotite, 10 to 15 percent orthoclase, and 5 percent epidote. Andesine and biotite occur both as phenocrysts and with the other minerals in the fine groundmass.

\section{INTRUSIVE QUARTZ MONZONITE}

Intrusive quartz monzonite forms a stock and associated dikes in the central part of the Northgate district, and several related dikes near the east edge of the district (Steven, 1957a, p. 365-372). The main body of the stock lies on the western flank of the Medicine Bow Mountains along the north margin of North Park. To the east the stock passes into a complex of dikes that cuts the older gneisses on Pinkham Mountain into a gross breccia. Related dikes occur near the northeast edge of the mapped area, and the west margin of a stock of similar rock lies about half a mile farther east. This last body constitutes the entire eastern flank of the Medicine Bow Mountains in the vicinity of the Colorado-Wyoming State line, but it had not been mapped at the time this report was prepared. 
The texture of the intrusive quartz monzonite in the Northgate district varies widely. The main body of the stock is made up largely of a medium-to coarse-grained, somewhat porphyritic rock, but a finegrained, distinctly porphyritic facies also is widespread. Rectangular pink microcline phenocrysts half an inch or more in length are set in a variable groundmass of pink microcline, white plagioclase (oligoclase or calcic albite), and glassy quartz. Biotite varies widely in abundance; in some places it constitutes nearly 10 percent of the rock and in other places it is absent. On fresh surfaces the rock appears mottled pink and gray.

The rock in some of the larger dikes and irregular masses on Pinkham Mountain resembles that in the central part of the stock, but most of the rock in the dikes, and some near the margin of the main body is fine grained to medium grained and aplitic. Biotite is a minor constituent in most of this peripheral rock, and the quartz and feldspar form an aggregate of anhedral grains with scattered phenocrysts of microcline and quartz. Small masses of fine-grained pegmatite are common in some dikes, and all gradations exist between these and the surrounding aplitic rock.

The rock in most of the small dikes near the northeast edge of the district is a very fine grained, porphyritic quartz monzonite. The phenocrysts in this rock are plagioclase, whereas those in the stock are microcline, and the groundmass is a very fine grained aggregate of quartz, feldspar, and biotite. The larger bodies near the northeast edge of the district are made up of a somewhat coarser grained rock that commonly resembles that in the stock and larger associated dikes.

\section{SEDIMENTARY ROCKS}

The sedimentary rocks in the Northgate district range in age from Permian to Recent. Folded Permian, Mesozoic, and early Tertiary rocks underlie the North Park basin and throughout much of the area they are covered by Quaternary terrace gravel, alluvium, and dune sand. The lower part of the stratigraphic section, extending through the Dakota group as used by Lee (1927) is fairly well exposed on Sentinal Mountain and at places along the flank of the Medicine Bow Mountains in the southeastern part of the district; the Benton shale, Niobrara formation, and lower 60 feet of Pierre shale can be observed along the edge of the terrace above Pinkham Creek and west of Sentinal Mountain. The remainder of the Pierre and the early Tertiary Coalmont formation found elsewhere in North Park are not exposed in the Northgate district.

Nonmarine sediments of Oligocene and of Miocene and Pliocene(?) age fill Tertiary valleys cut in the Precambrian rocks. Deposition of these sedimentary strata were separated from the sedimentation of 
Mesozoic and early Tertiary time by an interval which embraced the closing phases of the Laramide orogeny and the subsequent deep erosion during the early Tertiary.

Table 1 summarizes the stratigraphy in the Northgate district and adjacent areas. Some of the information on the Pierre shale and Coalmont formation was furnished by D. M. Kinney (written communication, 1957), who studied these formations in adjoining areas south of the Northgate district.

\section{PERMIAN ROCKS}

SATANKA(?) SHALE

The oldest sedimentary formation in the Northgate district is a soft, brick-red silty shale that is poorly exposed along the flank of the Medicine Bow Mountains east of Sentinal Mountain. It commonly is covered by talus and debris washed down from the Precambrian rocks exposed higher on the mountains, and no well-exposed section was seen. The shale attains a maximum thickness of about 50 feet. Generally, however, it is less than 50 feet thick and it is absent at many places in the district where the contact between the Precambrian crystalline rocks and the later sedimentary rocks is exposed.

The red shale conformably underlies a limestone believed to be equivalent to the Forelle limestone in the Laramie Basin, and for this reason the red shale is provisionally correlated with the Satanka shale of Permian age.

\section{FORELLE(?) LIMESTONE}

A distinctive limestone 8 to 15 feet thick occurs near the base of the sedimentary strata in the northern part of North Park. Along the flank of the Medicine Bow Mountains east of Sentinal Mountain it overlies as much as 50 feet of red silty shale; elsewhere it either rests directly on Precambrian rocks or is separated from them by only a few feet of red shale. Beekly (1915, p. 21) and York (1957, p. 75) describe a thin limestone lying directly on Precambrian along the eastern flank of North Park southeast of the Northgate district, and Gorton ${ }^{1}$ noted a similar limestone close to the base of the sedimentary section near the southeast corner of North Park.

The Forelle(?) limestone in the Northgate district is commonly obscured by debris of Precambrian rocks, and throughout much of the area it is poorly exposed. In some places it is a hard, nearly homogeneous, light-gray limestone containing few impurities, but more generally the limestone is very thin bedded, and the laminae are some-

\footnotetext{
1 Gorton, K. A., 1941, Geology of the Cameron Pass area, Grand, Jackson, and Larimer Counties, Colorado: Michigan Univ. Ph. D. thesis, p. 15.
} 


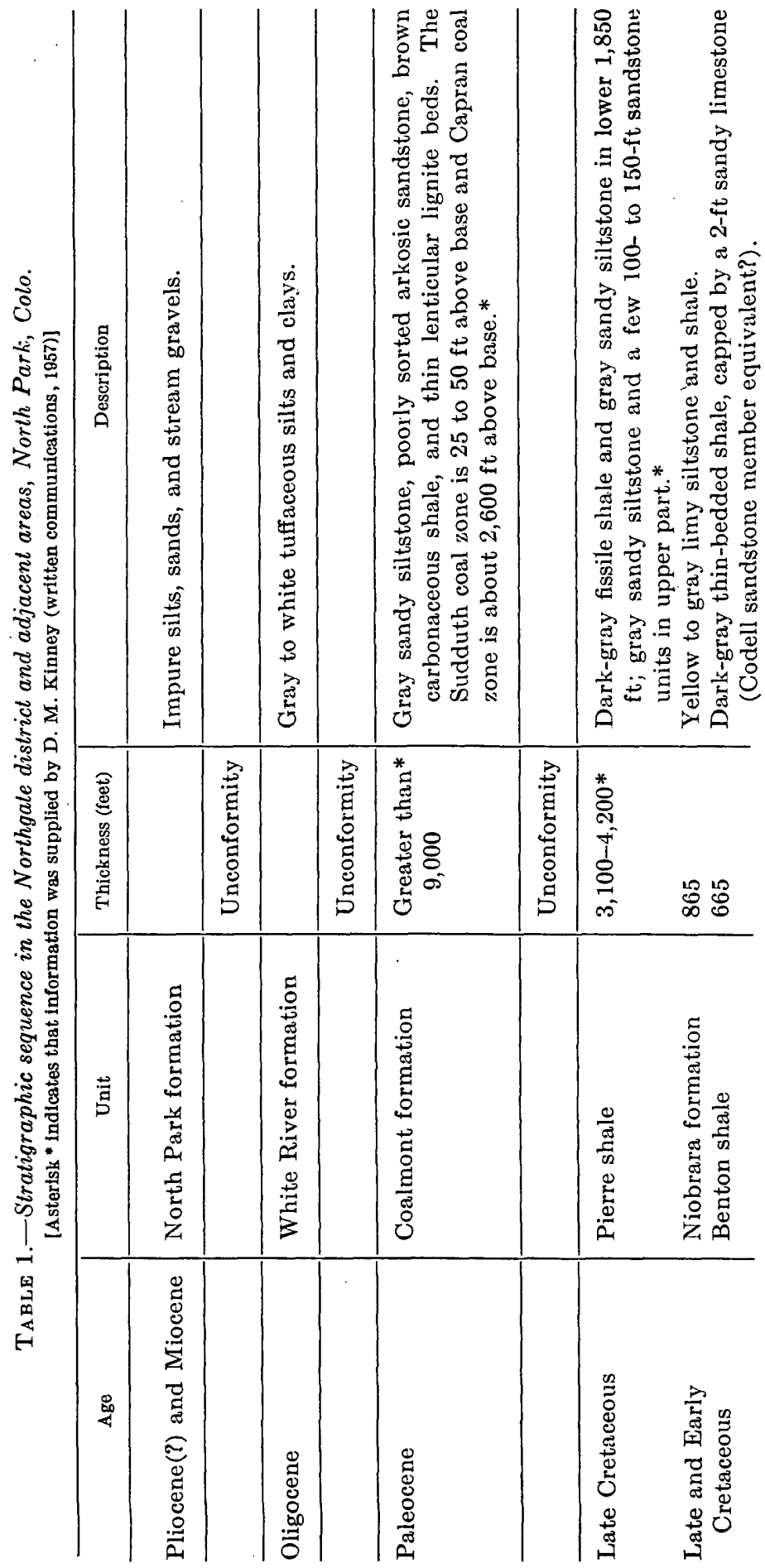


GEOLOGY AND FLUORSPAR DEPOSITS, NORTHGATE DISTRICT 337

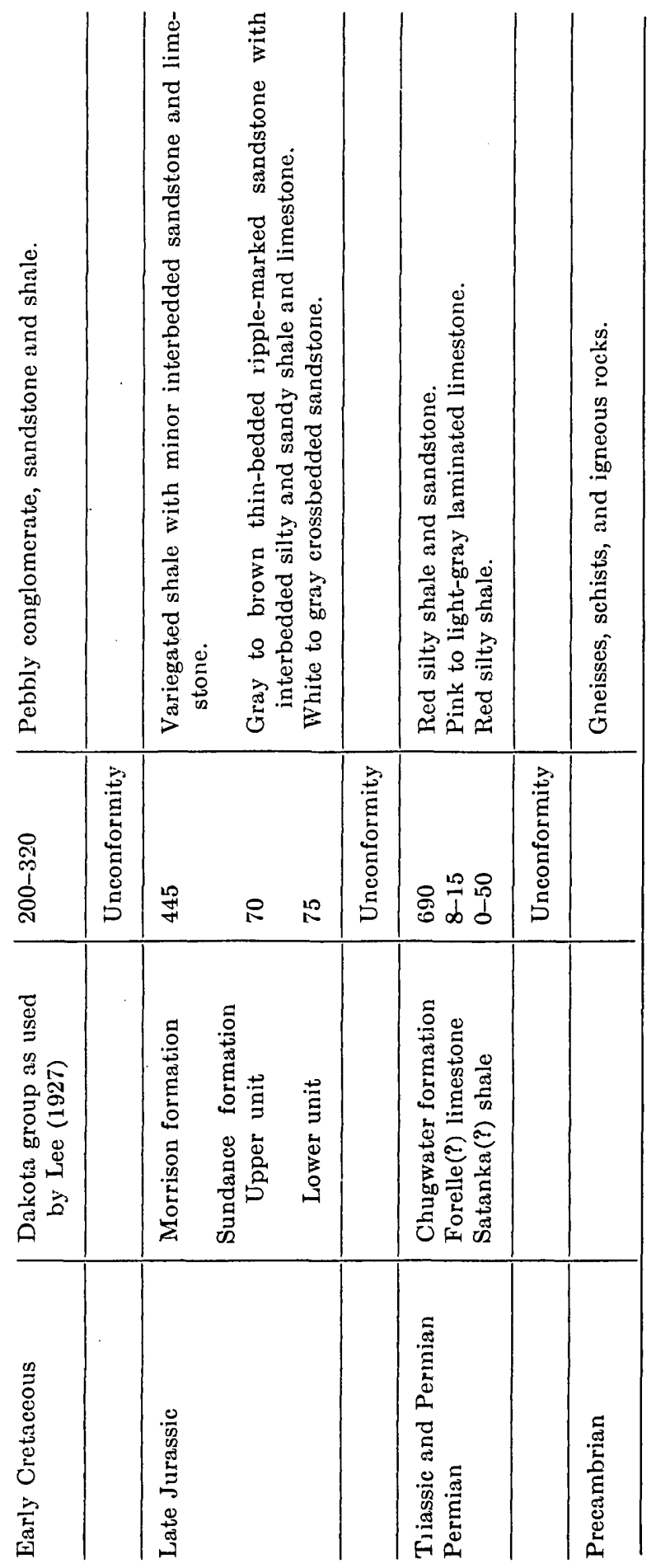


what crinkled. Where impurities are abundant, the color ranges from light gray to pinkish and lavender. In places, particularly where it is closely folded, the limestone is somewhat recrystallized.

Although no fossils were found, the limestone is similar in appearance, stratigraphic position, and thickness to the Forelle limestone in the Laramie Basin described by Darton (Darton, Blackwelder, and Siebenthal, 1910, p. 7). Although the correlation is considered probable, it is not certain inasmuch as the Fountain and Casper formations and much of the Satanka shale found beneath the Forelle limestone in the Laramie Basin are absent in North Park. The age of the Forelle is not known. Thomas (1934, p. 1666) considers it to be an eastward-extending tongue of the Phosphoria formation, which generally is believed to be of early to middle Permian age.

\section{PERMIAN AND TRIASSIC ROCKS}

\section{CHUGWATER FORMATION}

Nonmarine strata, chiefly impure red shales and sandstones conformably overlie the Forelle(?) limestone. No fossils have been found in these strata, but the rocks occupy the same stratigraphic position and are similar lithologically to those of the Chugwater formation in the Laramie Basin to the east and northeast. The Chugwater formation is Permian and Triassic in age.

The Chugwater formation is soft, easily eroded, and typically crops out in a broad swale between the crystalline Precambrian rocks of the mountains and the hogback formed by the sandstones of the Dakota group. Exposures generally are poor, and it is difficult to measure a stratigraphic section accurately; nearly complete sections can be studied only along the northern flank of Sentinal Mountain (sec. 21, T. 11 N., R. 79 W.) and along Government Creek (sec. 36, T. 11 N., R. 79 W.). Careful mapping on the north slope of Sentinal Mountain demonstrates that the upper contact of the Chugwater is an unconformity; here sandstone beds near the top of the formation wedge out against the overlying Sundance formation. Exposures are too poor to determine the angle of discordance, but it probably is about $5^{\circ}$ at this locality.

On the northern flank of Sentinal Mountain, the Chugwater formation is about 690 feet thick; this probably is close to the maximum thickness of exposed Chugwater in the district. The lower 85 to 90 feet is poorly exposed, but apparently consists of brick-red, very silty shale containing a few thin limy beds. This segment is capped by a bed of red to pink thin-bedded and somewhat crinkled impure limestone about 3 feet thick. From about 90 to 490 feet above its base, the formation is composed of thinly laminated, brick-red, very silty shale and a few thin sandy layers. Near the middle of this unit the strata are sandy and are more massive; these beds are several feet 
thick, and typically are crossbedded on a small scale. The upper 200 feet of the formation consists of interbedded sandstone and silty shale. The sandstone ranges in color from buff to reddish, and typically is flecked with limonite stains from the weathering of ferromagnesian grains; it is thin bedded and generally weathers out in slabs 1 to 3 inches thick which show crossbedding on a small scale. Angular to rounded clay fragments half an inch or more in diameter are widespread, but generally not abundant. Sandstone is most common toward the middle of the upper unit, but elsewhere silty shale similar to that in the lower parts of the formation is more abundant.

The upper sandstone beds in the Chugwater are similar to and perhaps equivalent in part to the Jelm formation as restricted by Pipiringos $(1953$, p. 37$)$. The rocks are too poorly exposed to map separately, and they are thus included in the Chugwater.

Stratigraphio section of the Chugwater formation, measured along the Union Pacific RR. right-of-way on the north slope of Sentinal Mountain (sec. 21, $T$. 11 N., R. 79 W.)

Chugwater formation:

Contact with Sundance formation.

Covered, chiefly red silty shale; contains at least one sandstone bed near the middle

Sandstone, buff and red, impure, slabby, crossbedded; spotted with limonite stains

Siltstone and sandy siltstone, brick-red, containing some greenish to white layers, some thin sandstone layers

Silty sandstone, brick-red, very fine grained, thin-bedded.

Sandstone, gray to white, crossbedded, containing some associated red siltstone

Siltstone, jellow

Sandstone, gray to buff, fine-grained, crossbedded ; spotted with limonite stains.

Covered, propably red silty shale in large part

Sandstone, buff, fine-grained; spotted with limonite stains

Silty shale, brick-red, very thin bedded, minor sandy layers...-...--

Sandy siltstone, brick-red, blocky, minor crossbedding.---.--.---.--

Silty shale, brick-red, very thin bedded, minor sandy layers--.---.--

Covered, upper $30 \mathrm{ft}$ probably as above, lower $10 \mathrm{ft}$ probably same as below

Sandy siltstone, red, massive, crossbedded on small scale

Silty sandstone, red, fine-grained, slabby

Sandy siltstone, red, fine-grained, poorly exposed

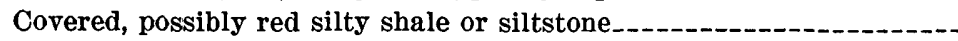

Sandy siltstone, brick-red

Silty limestone, brick-red to pink, very thin bedded somewhat crinkled, flecked with black spots.

Siltstone and sity shale, brick-red, thin-bedded; contains some thin

limy beds 


\section{JURASSIC ROCKS}

\section{SUNDANCE FORMATION}

The Sundance formation as referred to in this report consists of a series of sandstone, shale, and minor limestone beds about 145 feet thick that rests unconformably on the Chugwater formation and grades upward into the variegated shales of the Morrison formation. The upper contact is well exposed along the railroad tracks on the north slope of Sentinal Mountain where a stratigraphic section was measured; there is no evidence here for the marked unconformity at the top of the Sundance noted by Lee $(1927$, p. 17) farther north in Wyoming, and the contact with the overlying Morrison formation appears completely gradational. The base of the lowest variegated shale unit typical of the Morrison formation was taken as the top of the Sundance.

The Sundance formation had not been reported from North Park when the fieldwork in the Northgate district was done, although Gorton ${ }^{2}$ had pointed out that the 84 to 110 feet of sandstone at the base of the sequence he called the Morrison formation might correlate with the Sundance. Fossils were collected from the middle and upper parts of the Sundance formation along the Union Pacific Railroad right-of-way in secs. 20 and 21, T. 11 N., R. 79 W., from the banks of an old road cut along the boundary between secs. 15 and $22, \mathrm{~T} .11 \mathrm{~N}$., R. $79 \mathrm{~W}$., and from a natural outcrop near the northeast corner of sec. 27 , T. 11 N., R. 79 W. These were examined by Ralph W. Imlay of the U.S. Geological Survey, who reported them typical of the marine Upper Jurassic of the region. The species identified were:

Trigonia quadrangularis Hall and Whitfield

aff. T. sturgisensis Whitfield and Hovey

Tancredia sp.

Quenstedtia sp.

A detailed stratigraphic section was measured along the Union $\mathrm{Pa}$ cific Railroad right-of-way on the northern flank of Sentinal Mountain. Here the basal unit of the Sundance formation is a white to gray, crossbedded sandstone about 75 feet thick. The crossbedding is of the sweeping, tangential variety generally believed to result from wind action. The rock is soft, and the outcrop commonly is obscured by debris from overlying, harder sandstone beds.

The middle part of the Sundance formation along the northern flank of Sentinal Mountain is about 47 feet thick, and consists of interbedded yellowish-brown sandy siltstone, thin-bedded and ripple-

\footnotetext{
${ }^{2}$ Gorton, K. A., 1941, Geology of the Cameron Pasa area, Grand, Jackson, and Larimer Counties, Colo. : Michigan Univ. Ph. D. thesis, p. 20.
} 
marked sandstone, and minor gray shale. The thin sandstone beds are resistant and commonly stand slightly higher in outcrop than the adjacent rocks. A thin cherty limestone less than 1 foot thick occurs just below the middle of this part of the formation, and a hard, homogenous light-gray limestone about 2 feet thick occurs at the top of the unit.

The upper 23 feet of the formation consists of yellowish to gray silty shale and contains many sandstone beds near the top. This unit was included in the overlying Morrison formation in the two preliminary reports published on the Northgate district (Steven, 1953, 1954) because of the abundance of silty shale. However, the sandstone beds near the top contain the same marine fossils that are found in the underlying unit, and it thus seems more logical to include these marine strata with the Sundance.

The several units in the sequence of sandy strata between the top of the Chugwater formation and the base of the variegated shales of the Morrison formation can be differentiated at only a few places in the Northgate district; more commonly exposures are so poor that only the general limits of the sandy sequence can be established. Thus the strata were all mapped as Sundance, although it is possible that two formations may be represented.

The fossiliferous middle and upper units, of marine origin, are the most certain correlatives of the Sundance formation. The lower, eolian-type sandstone, on the other hand, may belong to a different formation. Both Reeside (1931, p. 1101) and Heaton (1939, p. 1155 and 1158) correlate an eolian sandstone at the base of the Jurassic strata in the northern Front Range of Colorado with the Entrada sandstone of western Colorado. This eolian sandstone apparently corresponds to the basal Sundance sandstone of Lee (1927, p. 15), and may be equivalent to the upper part of the Jelm formation as originally described by Knight (1917, p. 168). Pipiringos (1953, p. 37 ), working in the southern part of the Laramie Basin, restricted the Jelm formation to the lower part of the sequence that Knight called Jelm, and suggested that the upper part, which appears equivalent to the lower Sundance sandstone of Lee and the Entrada sandstone of Reeside and of Heaton, may correlate with the Nugget-Navajo sequence in Utah and southwestern Wyoming. The basal Jurassic sandstone in the Northgate district probably is equivalent to this eolian sandstone of uncertain correlation, but the data here are too sparse to solve any of the problems in regional stratigraphy. Thus it was considered expedient to follow Lee $(1927$, p. 15-16) and include all of the sandy strata at the base of the sequence of Jurassic rocks in the Sundance formation. 
Stratigraphic section of the Sundance formation measured along the Union Pacific RR. right-of-way on the north slope of Sentinal Mountain (secs. 20 and 21, T. 11 N., R. 79 W.)

Contact with the Morrison formation.

Siltstone and sandstone, yellow, thin-bedded

Siltstone and silty shale, gray; some sandstone

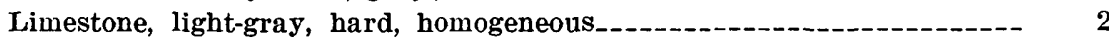

Siltstone and sandstone, yellow, platy

Sandstone, white and gray, thin-bedded, ripple-marked.

Siltstone, yellowish-brown; contains some gray shale. Thin $(0.5-1 \mathrm{ft})$ cherty limestone bed near top

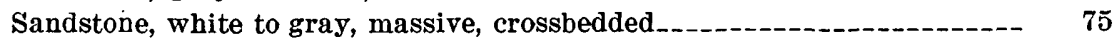

Contact with the Chugwater formation.

\section{MORRISON FORMATION}

The nonmarine Morrison formation of Late Jurassic age conformably overlies the Sundance formation, and in turn is overlain unconformably by sandstone beds of the Dakota group as used by Lee (1927). Although the beds in the Morrison and Dakota are nearly parallel, the basal unit of the Dakota group varies greatly in thickness, and locally some distinctive tuffaceous beds near the top of the Morrison formation are cut off at a low angle against the base of the Dakota. These relations suggest that the top of the Morrison formation is marked by an irregular erosion surface.

The rocks in the Morrison formation weather easily and only a few are exposed. A thick soil zone commonly covers the formation on low slopes, and steeper slopes generally are covered by talus and wash from the adjacent sandstones of the Dakota.

The Morrison formation is approximately 445 feet thick where measured along the Union Pacific Railroad right-of-way on the northern slope of Sentinal Mountain. The lower 105 feet of the formation consists largely of variegated red, gray, and green silty shale and contains minor lenses of sandstones. This unit is overlain successively by about 60 feet of yellow to brown siltstone and silty sandstone and a few lenses of red shale, about 220 feet of greenish-gray clay shale containing minor sandstone, and a little more than 60 feet of interbedded tuffaceous white to gray siltstone, gray clay shale, and minor limestone. Individual beds are lenticular. Although the distribution of rock types in the formation varies locally, it is generally similar throughout the district.

No fossils were found in the Morrison formation in the Northgate district. It is correlated with known Morrison elsewhere by lithologic similarity and stratigraphic position. 
Stratigraphic section of the Morrison formation measured along the Union Pacifio RR. right-of-way on the northern slope of Sentinal Mountain (sec. 20, T. 11 N., R. 79 W.)

Contact with Dakota group as used by Lee (1927). I'eet

Clay shale, light-gray

Tuffaceous siltstone, light-gray to white, massive, conchoidal fracture

Limestone, brown to gray

Tuffaceous siltstone, white, conchoidal fracture-_-_-_-_-_- 13

Clay shale, greenish-gray-_-_-_-_-_- 160

Sandstone, brownish-gray

Clay shale, greenish-gray

Siltstone and silty sandstone containing lenses of red shale, yellow

clay-ball conglomerate._- 60

Silty shale, variegated red, gray, and green

Contact with the Sundance formation.

445

CRETACEOUS ROCKS

\section{DAKOTA GROUP AS USED BY LEE (1927)}

Lee $(1927$, p. 17-23) subdivided the beds of conglomerate, sandstone, and shale at the base of the sequence of Cretaceous strata in northern Colorado and southern Wyoming into five units which he referred to the Dakota group, a series of rocks he believed were deposited as nonmarine strata near the margin of the advancing Cretaceous sea. Lee's units, consisting of a lower sandstone, lower shale, middle sandstone, upper shale, and upper sandstone, can be recognized in the Northgate district, although the thicknesses of some of the units vary greatly from place to place. The conglomeratic, sandy, and shaly beds in the lower part of the sequence are lenticular, and contain local accumulations of impure lignite and carbonaceous shale that suggest nonmarine deposition. The sandstone and shale beds in the middle and upper parts of the sequence are more persistent and even grained, and probably are of marine origin.

In two preliminary reports published on the Northgate district (Steven, 1953; 1954) the age of the Dakota was given as Early and Late Cretaceous. This was in conformity with the age given by Cobban and Reeside (1952, chart 106) for the Dakota in North and Middle Parks, Colo. Recognition of Mowry shale equivalents in the basal part of the overlying Benton shale, however, shows this designation to be in error as the Mowry itself is uppermost Lower Cretaceous (Cobban and Reeside, 1952, chart 106). Thus the Dakota in the Northgate district is wholly Early Cretaceous in age.

The sandstone and conglomeratic beds in the Dakota are the most resistant sedimentary rocks in the Northgate district and typically form ridges. The lower conglomeratic sandstone forms the crests of Sentinal Mountain and of the hogback that parallels the front of 
the Medicine Bow Mountains east and southeast of Sentinal Mountain. The middle and upper sandstone units generally form minor ridges downdip from these crests.

The lower sandstone is composed of lenticular beds of pebble conglomerate, conglomeratic sandstone, and poorly sorted sandstone. The thickness of the member varies greatly; it is about 120 feet thick on the northern slope of Sentinal Mountain, but less than a mile west, near where State Highway 125 crosses Pinkham Creek, it is only 41 feet thick. The conglomeratic beds are most abundant where the lower sandstone member is thickest.

The lower shale is an extremely variable unit consisting of white, gray, brown, and reddish silty shale, silt, and soft sandstone, containing local lenses of impure lignite and very carbonaceous shale. The rocks are soft and generally are poorly exposed. The lower shale ranges from about 20 to 30 feet in thickness.

The middle sandstone unit is a hard, gray to brown, even-bedded sandstone 20 to 30 feet thick. It consists largely of fine- to mediumsized quartz grains with sparse dark-colored grains. Small-scale crossbedding and irregular tubular concretions that may represent worm or mollusk borings commonly stand in low relief on weathered surfaces. This is the most regular and persistent unit in the Dakota in the Northgate district.

The upper shale in the two stratigraphic sections measured is largely a dark bluish-black, bituminous clay shale. At the north end of Sentinal Mountain this black shale is about 35 feet thick and is underlain by about 10 feet of lighter gray shale containing some interbedded silty and sandy layers. Farther south, on the western flank of Sentinal Mountain and on the hogback east of Sentinal Mountain, a thin sandstone bed occurs in the middle of the unit, and the shale above and below the sandstone is lighter colored and less bituminous than that in the measured sections. The total thickness of the upper shale unit ranges from about 35 to 45 feet.

The upper sandstone unit consists of lenticular beds of yellowishbrown platy siltstone, silty sandstone, and sandstone, and minor limestone lenses. One persistent sandstone bed about 12 feet thick is exposed on the western flank of Sentinal Mountain and on the hogback east of the mountain; it is a hard, grayish-brown, evenly bedded rock that occurs near the middle of the upper sandstone unit. The persistent sandstone is absent in the section exposed near where State Highway 125 crosses Pinkham Creek west of Sentinal Mountain; in this locality, sandy limestone lenses are much more abundant than elsewhere in the district, and constitute about 20 percent of the unit. The total thickness of the upper sandstone ranges from about 80 to 100 feet. 
Variations in thickness of the Dakota group as a whole apparently are accounted for chiefly by variations in thickness of the lower conglomeratic sandstone unit, which, in turn, probably is the result of deposition on an irregular erosion surface. In the 2 stratigraphic sections measured, the difference in total thickness is approximately 123 feet, and thinning of the lower sandstone accounts for about 80 feet of this.

Although it is difficult to correlate the units with certainty, Beekly (1915, p. 30-34) apparently included only the lower three units described here in his Dakota sandstone; in the Northgate area at least he mapped the upper shale and upper sandstone units as Benton. Thus his Dakota here may be equivalent to the Cloverly formation defined by Darton (1904, p. 399) and widely used in parts of Wyoming. Miller (1934, p. 11-12), in his study of the McCallum anticlines oil field in east-central North Park, used the same limits for the Dakota that are used in this report.

A recent group of papers published in the Guidebook, Eighth Annual Field Conference, Laramie Basin and North Park (Wyoming Geol. Assoc., 1953) showed little uniformity in nomenclature used for the strata here called Dakota group as used by Lee (1927). Oster $(1953$, p. 40,42$)$ followed the nomenclature in common usage in central Wyoming and split the sequence into the Cloverly formation, Thermopolis shale, and Muddy sandstone. Gorton (1953, p. 88) applied the name Dakota group in virtually the same manner used in this report. Welsh $(1953$, p. 100) called the lower conglomeratic unit the Cloverly formation and the upper units Thermopolis shale and Muddy sandstone. Steven (1953, p. 108) used the name Dakota sandstone for the same rocks called Dakota group in this report. Sims and Goth (1953, p. 156) called the upper sandstone the Muddy, did not apply any name to the strata in the middle part of the sequence, and called the lower conglomeratic unit DakotaLakota.

A similar variety of usage by different authors appears in the Guidebook to the geology of North and Middle Park basins, Colorado (Rocky Mountain Association of Geologists, 1957).

Waagé (1955) restudied the Dakota group in the foothills area of the northern Front Range, Colo., and grouped Lee's (1927) 5 informal units into 2 formations separated by a disconformity. The lower of these formations, the Lytle formation, includes the sandy and conglomeratic beds of Lee's lower sandstone unit, and the lower part of the overlying lower shale unit. Waagé named the remainder of the Dakota group the South Platte formation, and locally subdivided it further into members. Waagés report was published after the fieldwork and most of the report writing for the present report 
were completed, and it was not practicable to field check the Dakota group in the Northgate district to see whether equivalents of Waagés subdivisions could be recognized.

Stratigraphic section of the Dakota group as used by Lee (1927), measured in the vicinity of the Union Pacific RR. right-of-way on the northwestern flank of Sentinal Mountain (sec. 20 T. 11 N., R. 79 W.)

Contact with Benton shale.

Feet

Siltstone, yellowish-brown; contains some sandy limestone lenses____._._ $\quad 48$

Sandstone, gray to brown, hard, even-bedded

Sandy siltstone, yellowish-brown; includes some sandstone lenses_-_._- 40

Clay shale, black, bituminous... 35

Shale, bluish-gray; and some sandy and silty shale

Sandstone, gray to brown, hard, even-bedded 28

Siltstone, variegated white and red, soft

Sandstone, pebbly sandstone; and conglomerate_._. 122

Contact with Morrison formation.

Stratigraphic section of the Dakota group as used by Lee (1927) measured just west of State Highway 125 and south of Pinkham Creek (secs. 19 and 20, T. 11 N., R. 79 W.)

Contact with Benton shale.

Siltstone and silty sandstone, yellowish-brown, crossbedded; contains about 20 percent of sandy limestone. 80

Clay shale, bluish-black, bituminous____ 35

Sandstone, gray to brown, fine-grained, even-bedded, hard

Shale, carbonaceous, black containing impure carbonaceous sandstone and minor lignite

Sandstone, yellow to brown, fine-grained, soft 8

Silty shale, white

Sandstone, yellow and brown, fine-grained, crumbly

Silty sandstone, white, poorly cemented. 5

Sandstone, buff to yellow, fine-grained, well-sorted

Conglomerate and pebbly sandstone, poorly sorted, lenticular._._. 13

Contact with Morrison formation.

BENTON BAALE

The Benton shale is poorly exposed throughout most of the Northgate district and can be studied in moderate detail only along the edge of the terrace above Pinkham Creek west of Sentinal Mountain. Elsewhere the formation is generally covered by thick soil or by wash from nearby outcrops of hard sandstones in the Dakota group.

The Benton shale, aggregating approximately 665 feet in thickness, is composed largely of thin-bedded dark-gray shale and many interbedded bentonite layers. Some of the shale in the lower half of the formation, and particularly in the lower 100 feet, is thinly laminated 
and weathers out as distinctive silvery chips. Fossil fish scales are very abundant in the thinly laminated shale and many bentonite layers are interbedded with it. Higher in the formation the shale becomes less fissile and passes into a typically thin-bedded drab-gray clay shale containing a few thin limy beds. Sporadic bentonite layers are much less abundant in the upper part of the formation than they are near the base. About 30 feet from the top of the formation the shale changes to a yellowish siltstone which is capped by a 2 -foot-thick bed of fossiliferous sandy limestone just below the upper contact. The changes in rock type are transitional and in most places are so minor that traceable subdivisions could not be established, and the whole sequence was mapped as a unit.

The transition from the upper part of the Dakota to the Benton shale is gradational, and in field mapping the contact was assumed to be at that place where the shale becomes fissile, gray, and has a low content of sand. This arbitrary and poorly defined contact could not be located accurately over much of the area because of the poor exposures. The thinly laminated shale containing abundant fish scales and numerous bentonite beds that comprises the basal part of the Benton shale in the Northgate district closely resembles and may be equivalent to the Mowry shale to the north in Wyoming.

The drab-gray clay shale that makes up the middle of the Benton shale in the Northgate district is so soft and poorly exposed that a reliable detailed section could not be measured or described and only a crude approximation of the total thickness was made. The yellowish limy siltstone near the top is more resistant, however, and tends to stand as part of a low ridge that includes the top of the Benton shale and the base of the overlying Niobrara formation.

Fossils from the thin sandy limestone marking the top of the Benton shale, collected near the south edge of sec. 19, T. 11 N., R. 79 W., were identified by W. A. Cobban (written communication, 1954) as Scaphites ferronensis Cobban, Prionocyclus cf. $P$. wyomingensis Meek, and Inoceramus dimidius White. These fossils are characteristic of the upper part of the Benton (Carlile shale of other areas), and the sandy unit that contains them may be equivalent in part to the Codell (Niobenton of local usage) sandstone member that marks the top of the Benton shale throughout a large area in northern Colorado.

It is difficult to correlate the sequence of rocks described here with those described by Beekly (1915, p. 34-39) for the Benton shale in North Park. Some of Beekly's descriptions lead to the conclusion that locally at least his Benton includes the upper two units of the Dakota group as defined in this report. Certainly the area on 
Beekly's geologic map shown as Benton shale on the northwestern flank of Sentinal Mountain is restricted to these units. Elsewhere, however, the basal beds of the Benton shale are described by Beekly as consisting of thinly laminated shale containing abundant fish scales, and in these places his lower contact corresponds closely with that used in this report. Beekly, and later Miller (1934, p. 12), listed members that they tentatively correlated with the Graneros shale, Greenhorn limestone, and Carlile shale. These units, however, could not be differentiated in the Northgate district. Beekly and Miller also gave an average thickness of about 165 feet for the formation, which contrasts sharply with the 665 feet given here. Thus it is probable that the Benton described by Beekly and by Miller is comparable to only a very slight degree with the Benton described in this report.

Detailed partial stratigraphic section of the lower part of the Benton shale (Mowry equivalent(?)) along State Highway 125 just south of Pinkham Creek (sec. 20,T. 11 N., R. 79 W.)

Covered.

Shale, gray, fissile; abundant fish scales.

Bentonite

Shale, gray, fissile; abundant fish scales.

Bentonite

Shale, gray, fissile to platy; abundant fish scales and a few very minor bentonite seams

Bentonite

Shale, gray, fissile; abundant fish scales.

Bentonite

Shale, gray, fissile; abundant fish scales

Bentonite

Shale, gray, thin-bedded ; abundant fish scales.

Bentonite

Shale, gray, thin-bedded; abundant fish scales.

Bentonite

Shale, gray, thin-bedded, slightly silty ; abundant fish scales.

Bentonite

Silty shale, gray to grayish-brown, blocky weathering; abundant fish scales

Bentonite

Silty shale, grayish-brown, thin-bedded.

Bentonite

Shale, gray, very thin-bedded; abundant fish scales and some brown silty layers.

Contact with Dakota group as used by Lee (1927) (conformable).

\section{NIOBRARA FORMATION}

Fair exposures of the Niobrara formation in the Northgate district, like those of the Benton shale, are found only along the edge of the 
terrace above Pinkham Creek west of State Highway 125. The harder limy beds crop out sporadically on the low slope leading up from the terrace to the western flank of Sentinal Mountain, but the outcrops are not abundant nor well exposed. The more limy beds in the Niobrara are somewhat more resistant than the Benton shale and the less calcareous shale in the Niobrara, and thus stand slightly higher topographically. The difference is so slight that it is generally difficult to trace individual beds in the field, but on aerial photographs four low ridges can be distinguished parallel to the outcrop of the upper sandstone unit of the Dakota on Sentinal Mountain. These ridges can be traced into the area of fair exposures so that the approximate stratigraphic position of the more resistant beds is known.

The Niobrara formation is made up of yellow-weathering limy shale and siltstone and minor limestone interbedded with dark-clay shale. The lowermost 60 feet of the formation consists of limy shale and siltstone. About 215 feet of dark-gray clay shale separates the lower calcareous beds from the next slightly resistant calcareous unit, which is about 24 feet thick and consists of thin-bedded yellow limy siltstone. Eighty feet of fissile dark-gray shale overlies this second calcareous unit, and in turn is overlain by about 485 feet of yellow to grayish-brown thin-bedded limy shale and siltstone with minor interbedded gray shale. The beds near the bottom and near the top of this upper unit are slightly more resistant than the adjacent beds and tend to stand slightly higher topographically.

Beekly (1915, p. 39) described the lower part of the Niobrara formation as a "**** highly fissile bluish-gray to brownish limestone, which occurs in layers ranging in thickness from almost papery laminae to bands 2 inches or more in thickness and which weathers light gray to chalky white.", and noted that "Fish scales and bones are almost invariably present in the lower limestone layers of the Niobrara ***." Although this description is not particularly applicable to the basal Niobrara in the Northgate district, according to W. R. Hail, Jr. (oral communication) it is accurate for the lower Niobrara along the west margin of North Park. The description also fits many aspects of the Mowry shale equivalent at the base of the Benton shale of this report, and indeed the lower contact of Beekly's Niobrara formation along the western flank of Sentinal Mountain (Beekly, 1915, pl. 12) corresponds closely with the base of the Benton shale as mapped in the present investigation. Thus the discrepancy between Beekly's map (1915, pl. 12) and plate 12 of this report probably resulted from a confusion of the two units. 
Stratigraphic section of the Niobrara formation measured along edge of terrace east of Pinkham Creek and west of State Highway 125 (secs. 19 and 30, T. 11 N., R. 79 W.)

Contact with Pierre shale.

F'eet

Silty shale and siltstone, yellow to grayish-brown, limy, with some darkgray shale 486

Shale, dark-gray, fissile 80

Siltstone, yellow, thin-bedded, limy _..._._._-_._-_._-_ 24

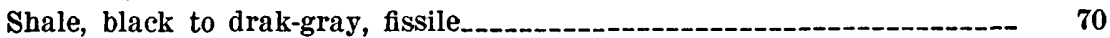

Clay shale, gray to brownish-gray _..._.

Silty shale and siltstone, yellow to gray, limy

Contact with Benton shale.

PIERRE SHALE

About 60 feet of very dark, thin-bedded shale overlying the highest yellowish calcareous shale assigned to the Niobrara formation is exposed along the edge of the terrace east of lower Pinkham Creek. From its stratigraphic position, this shale is probably the lower part of the Pierre shale. So little of this shale is exposed in the Northgate district that a detailed discussion is not warranted.

According to D. M. Kinney (written communication, 1957), the Pierre elsewhere in North Park ranges from about 3,100 to 4,200 feet in thickness, and consists largely of dark-gray fissile shale in the lower 1,850 feet, overlain by gray sandy siltstone with a few tan- to brown-weathering, fine- to medium-grained sandstone units 100 to 150 feet thick.

\section{TERTIARY ROCKS}

\section{WHITE RIVER FORMATION}

Grayish to white tuffaceous silt and clay beds of the White River formation of Oligocene age partly fill old valleys cut in the Precambrian rocks of the Northgate district. The White River rocks are soft and easily eroded, and the surface cut on them generally is significantly lower than that on the nearby Precambrian rocks. Although natural exposures are few and for the most part limited to streambanks or minor gullies on steep slopes, the limits of the formation generally are marked by an abrupt steepening in slopes; and the distribution of the White River formation shown on the geologic map (pl. 12) is fairly accurate. The rocks are best exposed in the many road and railroad cuts in Lawrence Creek valley and along upper Camp Creek.

The rocks of the White River formation in the Northgate district are made up for the most part of white, light-gray, greenish-gray, or tan ashy silt beds containing variable amounts of intermixed clay and sand. Almost all unweathered rocks are somewhat cemented by 
calcite, and many contain small, irregular to tubular concentrations of calcite crystals about half an inch in maximum diameter. Some of the more limy beds are hard and are conspicuous as ledges, even in weathered exposures. The relative proportions of clay, silt, and sand vary widely. Although some of the coarser grains are as much as half an inch or more in diameter, most of the grains are sand or silt size and generally are less than $0.5 \mathrm{~mm}$ in diameter. Most of the grains are angular to subangular, but subrounded grains are found in a few of the more sandy beds. Where clay is a major constituent, the rock generally is light gray, greenish gray, or buff, contains less calcite cement, and is softer than the associated lighter colored silty or sandy beds. A few of the clayey beds contain sparse, poorly formed pisolites. Small gastropod fossils were noted at several localities.

Reworked volcanic ash constitutes a significant proportion of the White River formation in the Northgate district. Thin flakes of biotite, ranging from irregular fragments to well-formed hexagonal plates, are widely distributed and in places make up 3 percent or more of the rock. In appearance, these flakes are unlike the biotite crystals found in the surrounding Precambrian rocks, and generally are much smaller and more nearly euhedral. Cursory microscopic examination showed the coarser grains to be mostly quartz, feldspar, and biotite, but in part to be volcanic glass; the glass is much more abundant in the finer fragments than it is in the sand-sized particles.

Although most of the sediments seem to be water laid, a few of the layers have features indicating subaerial deposition. One hard, calcite-rich specimen contained nearly 1 percent of thin, generally euhedral biotite flakes showing completely random orientation. These flakes were scattered uniformly throughout the rock. The residue left after the rock was leached by acid was composed almost entirely of fairly well sorted, angular fragments of quartz, feldspar, biotite, and volcanic glass. Most of the grains were less than $0.1 \mathrm{~mm}$ in diameter. The degree of sorting, angularity of fragments, and random orientation of biotite flakes suggest an air-laid tuff.

Scattered beds of poorly sorted arkosic sandstone and pebble conglomerate composed of locally derived materials are fairly common in the White River formation along the margins of the old valleys and in minor tributaries. Nowhere, however, do these coarser clastic rocks make up more than a few percent of the formation, and they comprise an anomalously small fraction of the rocks considering the steepness of the topography at the time of deposition.

The dominant fine-grained, tuffaceous rocks are lithologically similar to the ashy beds in the White River group toward the northeast in Wyoming, and numerous vertebrate fossils collected and 
identified by S. H. Knight (1953, p. 71) and P. O. McGrew (written communication, 1950) of the University of Wyoming show that these beds are the same age as the Chadron formation of the White River group in South Dakota. According to McGrew (1953, p. 62, 63), however, the well-defined subdivisions of the White River group in South Dakota and eastern Wyoming lose their identity toward the west, and White River is reduced from group to formation rank across the Laramie Mountains.

\section{NORTH PARK FORMATION}

Light-gray, impure silts and sands of the North Park formation of late Miocene and possibly early Pliocene age are widely exposed in an old valley extending northwest from the Northgate district along State Highway 125. Remnants of this formation east of the North Platte River are found near lower Camp Creek, along State Highway 125 just north of Watson Mountain, and near the northeast corner of the Northgate district. The formation is well exposed about 15 miles south of the Northgate district, where it forms a northwestwardtrending syncline extending across south-central North Park. The stratigraphy of the North Park formation in the North Park syncline and in the Saratoga-Encampment Valley northwest of the Northgate district has been described by Montagne and Barnes (1957, p. 55-60).

To the west and northwest of the Northgate district, most of the materials in the North Park formation are nearly unconsolidated, and the topography is low and rolling. Although the contacts are rarely exposed, the edge of the formation is marked by an abrupt change in topography from low areas underlain by the soft sedimentary rocks to the surrounding mountainous areas where igneous and metamorphic rocks are exposed. Light-gray to tan silty sand dominates in the North Park formation adjacent to the Northgate district, although thin pebbly beds and clayey layers constitute as much as 10 percent of the formation locally. The sands are poorly sorted and commonly contain scattered small pebbles and very coarse sand grains mixed with the finer sand and silt-sized particles. The percentage of clay and silt varies widely but in general it is much less than that of sand. The sand- and silt-sized grains tend to be subangular to subround and consist of abundant quartz and feldspar and variable amounts of biotite, hornblende, and magnetite. The larger grains and pebbles include rock fragments of several types found in the surrounding Precambrian metamorphic and igneous terrain. Some conglomeratic layers contain abundant clay fragments as much as half an inch in diameter set in a sandy matrix.

Although the sandy material generally is only slightly consolidated, most specimens effervesce freely in dilute hydrochloric acid and many 
exposures show some fairly hard, calcite-cemented layers a few inches to a few feet thick. The harder beds commonly are more sandy than the adjoining beds. Irregular opaline nodules as much as several inches in diameter are locally abundant on weathered surfaces and apparently are residual from the weathering and erosion of softer surrounding sedimentary rocks. The nodules formed through local impregnation and partial replacement by silica of both the clayey and sandy material of the North Park formation.

Old stream gravels believed to be a local facies of the North Park formation cover an area about $21 / 2$ miles long and as much as 3,500 feet wide near the northeast corner of the Northgate district and are well exposed in a large gravel pit near the Colorado-Wyoming State line. These gravels were deposited in a broad valley that predates the present drainage system and is distinctly younger than the White River formation. The gravel consists largely of poorly sorted pebbles and sand, chiefly of volcanic rocks, and contains very subordinate silt and clay. It is typically crossbedded, and the grain size changes abruptly from layer to layer. Many pebbly beds have little sand or clay in the interstices and form loose aggregates. A few flat lenses of silty clay or fine silty sand occur with the coarser gravels, but these are sparse. Apparently most of the material was deposited in the shifting channels of a swift-flowing stream.

The gravels contain a high proportion of rhyolitic pebbles. These generally are well rounded, and although some are as much as 5 inches across, most of the pebbles range from 1 to 3 inches in diameter. Finer fragments of volcanic rocks are common, and even the sands contain abundant dark volcanic materials. The gravels contain pebbles of granitic rocks, pegmatite, hornblende gneiss, chert, and sandstone. The nonvolcanic pebbles are abundant locally, but generally constitute only a very small percentage of the gravels.

The gravels rest unconformably on the White River formation, and apparently were deposited before the surface of low relief that forms the crest of the Medicine Bow Mountains in this vicinity was cut. This surface is younger than the North Park formation (see "Geomorphology," p. 385 and the gravels probably belong to that formation: According to Montague and Barnes (1957, p. 56-58), volcanic conglomerates are abundant in the North Park formation in south central North Park, and predominate in the southeastern exposures of the formation where they are intercalated with laval flows and volcanic breccias of contemporaneous origin.

On the basis of vertebrate fossils collected at several places along the Saratoga-Encampment Valley northwest of the Northgate district, Montagne and Barnes (1957, p. 59) have dated most of the North Park formation in this vicinity as late Miocene in age. They 
specifically do not exclude a possible early Pliocene age for some of the higher beds, however, and McGrew (1951, p. 57) has reported lower Pliocene vertebrate fossils from the North Park formation in the Saratoga basin, Wyoming. For these reasons the age of the formation is given in this report as late Miocene and early Pliocene (?).

\section{SURFICIAI DEPOSITS}

Surficial deposits cover much of the floor of North Park in the Northgate district, but these were accorded scant attention during fieldwork. Time was too short to permit a detailed study, and the solution of most problems concerning these deposits would require data from a much wider area than that included in the Northgate district.

Stream gravels cap the low stream terrace marking the eastern flank of the flood plain along the North Platte and Canadian Rivers and lower Pinkham Creek, and these in turn are covered in part by more recent alluvium and wind-blown sand. A veneer of stabilized dune sand covers most of the interfluve areas along the south margin of the Northgate district, and active dunes constitute the North Sand Hills near the southeast corner of the district. Little or no sand is being added to the active dunes at this time, and movement involves a general eastward shift of sand that has not yet been stabilized by plant growth. Talus, landslide debris, and torrential fan deposits form local aprons at the base of steep slopes, and commonly obscure geologic relations along critical contacts. Recent alluvium forms broad flood plains along the major streams, as well as local irregular belts along secondary streams.

\section{STRUCTURE}

The geologic structure in the Northgate district is as varied as the rock types. Each successive movement during the complex metamorphism that formed the Precambrian gneisses of the Medicine Bow upland left its imprint on the rocks, and in part these earlier structures controlled the magmatic movements during the periods of igneous intrusion in later Precambrian time. The Permian, Mesozoic, and early Tertiary strata of. North Park were complexly folded and faulted during the Laramide orogeny in late Cretaceous and early Tertiary time, and the warping and faulting that resulted from later Tertiary deformation are recorded by the relations of the White River and North Park formations.

\section{STRUCTURAL FEATURES OF THE GNEISS COMPLEX}

Foliation and layering in the gneiss complex generally trend east to northeast, and dip steeply north (Steven, 1957a, pl. 48). Locally the attitudes differ markedly from the regional trends, particularly 
near the crests of folds and in the areas where the rocks became rheomorphic during the later stages of regional metamorphism. The rocks were closely folded during early orogenic and metamorphic stages, and in part were deformed significantly during later stages when local shearing and rheomorphism took place.

The detailed structural features of the different rock types in the gneiss complex have been discussed in appropriate sections of the earlier report on Precambrian rocks (Steven, 1957a); these features have little apparent bearing on the later structures in the district or on the fluorspar deposits and thus will not be discussed further here.

\section{STRUCTURAL FEATURES OF THE INTRUSIVE ROCKS}

The dacite porphyry and intrusive quartz monzonite, although perhaps unrelated, were intruded into similar environments. In contrast to the rocks in the gneiss complex, whose structures formed in a deepseated environment characterized by plastic flow and pervasive shearing, the intrusive rocks were emplaced at more shallow depths where fractures in the country rocks controlled the magmatic movements and the eventual shape of the bodies that solidified.

The faults containing the largest fluorspar deposits in the Northgate district cut the area that includes the intrusive bodies of quartz monzonite. In addition, this rock was the most favorable host for the deposition of fluorspar of the rocks cut by these faults. For these reasons, the structure of the quartz monzonite bodies will be discussed in greater detail than the structure of the other Precambrian rocks in the district.

\section{DACITE PORPHYRY DIKES}

The dacite porphyry dikes in the west-central part of the district were injected into a group of subparallel and nearly vertical fissures that trend slightly west of north. No offset was noted across any of the dikes, and apparently the fissures they fill are simple tensional cracks. The fine-grained rock in the dikes apparently was chilled quickly, indicating that the magma was injected into a cool and presumably shallow environment.

\section{STRUCTURES OF THE INTRUSIVE QUARTZ MONZONITE}

The intrusive quartz monzonite in the Northgate district forms a small stock and many related dikes (Steven, 1957a, p. 365-372). The stock, which occupies an area of about 7 square miles in the central part of the district, passes eastward into a complex network of dikes on the crest and flanks of Pinkham Mountain. Several dikes and irregular bodies of quartz monzonite cut the gneiss complex near the northeast margin of the mapped area, and a body of similar rock forms the whole eastern flank of the Medicine Bow Mountains near 
the Colorado-Wyoming State line. The west margin of this latter body trends nearly north about half a mile east of the mapped area. The abundance of small dikes between the two larger bodies suggests that the intrusive quartz monzonite is continuous between them at depth.

The intrusive quartz monzonite was emplaced largely by piecemeal magmatic stoping (Steven, 1957a, p. 368-370), and the configuration of the stock and the dikes was controlled for the most part by fractures in the country rock. The north margin of the stock, and the lacework fringe of dikes on Pinkham Mountain clearly show many of the details whereby the rising magma fissured and engulfed the overlying rocks. Internal structures, however, are generally absent in the rock.

The pattern of distribution shown by the network of dikes on Pinkham Mountain and by the north margin of the stock indicates that the emplacement of the quartz monzonite was controlled by two groups of fractures. One of these groups trends east to southeast, and apparently does not follow any of the known directions of weakness in the gneiss complex. Fractures of this group have the same general trend as the stock as a whole, and in general are fairly regular and persistent. They may have originated through the initial fracturing and forceful spreading of the roof of the magma chamber. Fractures parallel to, and nearly at right angles to the foliation comprise the other group of fractures. Dikes following these directions are more abundant and widespread than those following the east- to southeastward-trending fissures, but generally they are much more irregular and commonly do not persist far. They apparently filled smaller scale fractures and breccia zones along directions of inherent weakness in a mass of rocks already cut by more widely spaced master fissures of a different trend. The dikes and irregularly elongate masses of intrusive quartz monzonite in the northeastern part of the mapped area trend between N. $10^{\circ} \mathrm{W}$., and N. $40^{\circ} \mathrm{W}$., almost at right angles to the trend of foliation in the gneiss complex. A subordinate preferred trend for parts of the contacts of the irregular bodies is about parallel to the foliation.

A knowledge of the shape and distribution of the dikes is economically important, as the largest of the known fluorspar ore bodies are localized where faults of late Tertiary(?) age cut masses of the intrusive quartz monzonite (see "Fluorspar deposits," p. 396). The surface distribution of the quartz monzonite as mapped is shown on plate 12. Projection to depth, however, involves a great deal of conjecture, as the bodies seem to be extremely irregular in all dimensions. The widespread evidence for local stoping suggests that most dikes should become wider with depth, and the abundance of dikes on Pinkham Mountain suggests that the main body of the stock lies at shallow depths. 


\section{STRUCTURES RELATED TO THE LARAMIDE OROGENY}

The main outlines of the Rocky Mountains of northern Colorado formed during the Laramide orogeny in late Mesozoic and early Tertiary time. The broadly anticlinal arches of the Medicine Bow Mountains and the Park Range, and the intervening synclinal basin of North Park are major structural features in and adjacent to the Northgate district. Many smaller scale folds and numerous faults make the structure more complex. The folded sedimentary rocks in the broad basin of North Park are cut off abruptly on the north by a barrier of Precambrian rocks that was thrust up along the Independence Mountain fault, an eastward-trending thrust fault whose structural importance is secondary only to the major folds comprising the mountains and basin.

Lovering (1929, p. 90-91) has shown that the successive stages of the Laramide orogeny in the Southern Rocky Mountains began late in the Cretaceous period, while the Pierre shale was still being deposited, and continued throughout the Eocene epoch. The earliest stages of the orogeny outlined the general anticlinal and synclinal areas, but the sedimentary rocks in the basins were not greatly disturbed.

Most of the folding and faulting in the Northgate district took place in early Tertiary time, following deposition of the Middle Park formation of Cretaceous and Paleocene age and the Coalmont formation of Paleocene age in the Middle Park-North Park basin. The earlier basins and upwarps were more closely compressed and accentuated at this time, and many subsidiary folds and faults formed on the flanks of the older structures. The last stage of the Laramide orogeny in the vicinity of the Northgate district was manifested by the Independence Mountain fault, which cuts across all earlier Laramide structures.

The northeast corner of North Park (fig. 34) is marked by the intersection of the northwestward-trending folds and faults of the North Park basin, and the east-trending Independence Mountain fault zone. The northwestward-trending folds are open and dips are $60^{\circ}$ or less, although many of the anticlines are cut by reverse faults of widely different trends and directions of offset. Transverse faults offset some of the folds, and the character of folding commonly is markedly different on the opposing sides of such faults. The Independence Mountain fault zone dips $15^{\circ}-55^{\circ} \mathrm{N}$., and it transects the northwestward-trending structures at a high angle. Crystalline rocks of Precambrian age on the hanging wall of this zone were thrust up across the earlier structures in the sedimentary rocks, and the great structural discordance is clearly marked in the present topography by the fault-line scarp at the north end of North Park. The 


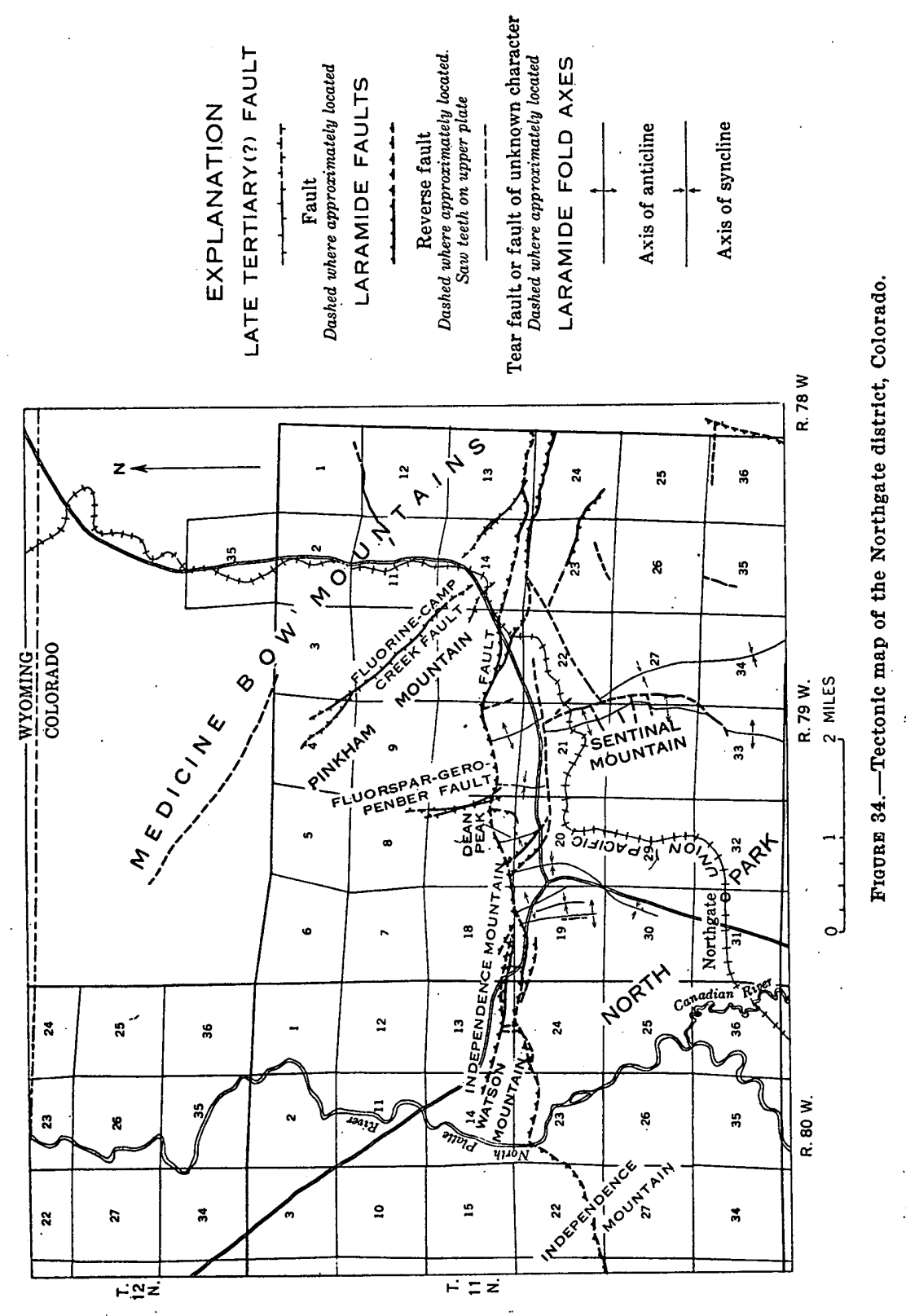


synclinal structure of North Park is still strong where it is interrupted by the Independence Mountain fault zone, and the original basin once must have continued much further north.

The complex pattern of structures formed during the Laramide orogeny apparently resulted from the influence of the basement of crystalline rocks, which is exposed in the cores of a few of the anticlines and underlies the rest of the North Park basin in the Northgate district at shallow depths. These basement rocks apparently reacted rigidly during the Laramide orogeny, and responded by fracturing the faulting to the stresses that caused folding in the overlying sedimentary rocks. This difference in response probably was due in part to the massive character of many of the crystalline rocks, but the light load of overlying sedimentary rocks probably was a strong contributing factor. Thus the basement rocks fractured and sheared while the folds in the overlying sedimentary rocks were still open. Therefore the direction of thrusting depended on the local directions of relief in the basement rocks, rather than on any systematic characteristic of folding in the sedimentary rocks.

\section{MEDICINE BOW ARCH}

Only a small segment of the western flank of the Medicine Bow arch is within the Northgate district. Relations are clearest along the front of the mountains south of the Independence Mountain fault, where the sedimentary strata of North Park dip generally $20^{\circ}-25^{\circ}$ away from the mountains, and the mountain front is offset by faults. Beekly $(1915$, pl. 12) shows a similar condition for most of the east margin of North Park, although the dips he measured are generally somewhat steeper than those found in the Northgate district. The arch of the Medicine Bow Mountains is bordered on the east by the generally synclinal Laramie Basin (Beckwith, 1938, 1942).

The anticlinal structure of the Medicine Bow Mountains is not apparent north of the Independence Mountain fault, where the Paleozoic and Mesozoic sedimentary strata on the western flank have been completely removed by erosion. The mountains are broader and more diffuse, and the poorly defined lower land between the Medicine Bow Mountains and the Park Range to the west has no apparent structural significance.

\section{NORTH PARK BASIN}

North Park marks a synclinal basin between the anticlinal arches of the Medicine Bow Mountains on the east and the Park Range on the west. Although the structural depression continues south beneath Middle Park, a low uplift near the divide between North Park and Middle Park divides it into separate basins (Beekly, 1915, p. 82). The north end of North Park is marked by the Independence Mountain 
fault, which cuts off both the structural and topographic basins sharply.

The broad synclinal structure and many smaller folds and faults form a complex pattern (Beekly, 1915, p. 83-93). Most of the faults in the Northgate district and along the northwest edge of the basin (Welsh, 1953, p. 99-100) are reverse faults and associated tear faults. In the vicinity of Cameron Pass, near the southeast corner of North Park, low-angle thrusts predominate (Gorton, 1953, p. 91-98).

Only the northeast corner of North Park is within the Northgate district, but the structures within this small area are varied and complex. They include the westward-dipping strata on the flank of the mountains, subsidiary folds and faults within the North Park basin, and the cross folds adjacent to the Independence Mountain fault.

\section{SENTINAL MOUNTAIN-DEAN PEAK FAULTED ANTICLINE}

The Sentinal Mountain-Dean Peak anticline is one of the largest subsidiary folds within the North Park basin. It is exposed for about 3 miles in the Northgate district, and can be distinguished on aerial photograph index sheets for 3 miles farther south to a point near the Canadian River. The crest of the anticline is highest within Sentinal Mountain and Dean Peak where erosion has bared the core of Precambrian rocks for more than 2 miles. The anticline has been cut off on the north near its maximum development by the Independence Mountain fault.

The structurally higher parts of the anticline have been strongly faulted (fig. 34), with a southern segment, Sentinal Mountain, being thrust eastward, and a northern segment, Dean Peak, being thrust westward. The two faulted segments are separated by an easttrending tear fault, now covered by the alluvium along Pinkham Creek, along which the axis of the anticline has been displaced about a mile.

The higher parts of the anticline are conspicuous in the present topography. The crest and western flank of Sentinal Mountain, which dominates the landscape in the northeastern part of North Park, are underlain by hard sandstone beds in the Dakota group as used by Lee (1927), and Precambrian rocks are exposed in a subsidiary ridge east of the main crest. On Dean Peak, the hard granitic rock in the center of the anticline has been stripped of overlying sedimentary rocks and stands out as a steep-sided hill.

Exposures on the western slope of Sentinal Mountain consist largely of north- to northwestward-striking sandstone beds in the Dakota, which dip $18^{\circ}-30^{\circ} \mathrm{SW}$. The axis of the anticline plunges southward at the south end of Srantinal Mountain, where the strike of the sand- 
stone beds in the Dakota swings eastward and then northward, and the dip changes to $10^{\circ}-15^{\circ} \mathrm{S}$, and then to $30^{\circ}-45^{\circ} \mathrm{E}$. Farther north, on the east side of Sentinal Mountain, the dip of the sandstone bed steepens to $60^{\circ}$ and the anticline is definitely asymmetric.

The eastern flank of the anticline on Sentinal Mountain is cut by a reverse fault. This fault begins on the southern nose of Sentinal. Mountain as a nearly vertical tear fault. The strike swings from nearly east at the south end, to northeast and then slightly west of north along the eastern flank of the anticline, and the dip becomes progressively less to the west as the strike swings more northerly. The dip of the fault along the eastern flank of Sentinal Mountain, where the displacement is greatest, is probably about $45^{\circ}-55^{\circ} \mathrm{W}$., although exposures are too poor to be certain. The fault ends at the north where it intersects the tear fault that separates the Sentinal Mountain and Dean Peak segments of the anticline. The core of the thrust block on Sentinal Mountain is cut by short, nearly vertical transverse faults, which strike nearly at right angles to the main reverse fault. These minor faults apparently resulted from unequal movements of different blocks of crystalline rocks in the core of the anticline during thrust faulting; they are shown chiefly by displacements of the Forelle(?) limestone at the base of the sedimentary section, and none has cut the overlying strata far enough to affect the Sundance formation.

The maximum displacement on the fault along the eastern flank of Sentinal Mountain is about 1,800 feet in section $A-A^{\prime}$ (pl. 12). Movement along the fault here thrust Precambrian rocks against the upper beds in the Dakota group, and at one time may have placed them adjacent to the lower part of the Benton shale. The stratigraphic throw on the fault decreases north and south of the line of section, and the axis of the anticline plunges in both directions from this local structural high.

The structures along the north end of Sentinal Mountain reflect the northerly plunge of the axis of the anticline in this area. The Forelle(?) limestone at the base of the sedimentary section nearly covers the Precambrian rocks in the core of the anticline near the northern base of Sentinal Mountain, indicating that the rocks here are much lower structurally than in the area of maximum displacement half a mile south. The beds between the lower Chugwater and the upper Benton on the western flank of the anticline are crossfolded along the northern slope of Sentinal Mountain, where the general direction of strike swings from north-northwest to northeast. The dips along the axis of this cross fold are about $10^{\circ}-15^{\circ} \mathrm{W}$., and on the northern limb they are as much as $45^{\circ} \mathrm{NW}$. 
Dean Peak constitutes another local structural high along the crest of the anticline, and it, too, is cut by reverse faults. In contrast to the structures found on . Sentinal Mountain, dips here are lowest on the east side of the anticline, and the steeper western flank is cut by two strong, east-dipping reverse faults in section $B-B^{\prime}$ (pl. 12). A general southward convergence of strikes on opposite sides of Dean Peak indicates that the axis of this segment of the anticline plunges southward. The north end of the anticline is cut off by the Independence Mountain fault where the belt of exposed Precambrian rock in the core of the fold is near its maximum width, and thus near the highest known part of the anticline.

The two eastward dipping reverse faults on the western flank of Dean Peak seem to merge into the tear fault along Pinkham Creek (pl. 12), and probably join at depth in section $B-B^{\prime}$ (pl. 12). Most of the displacement took place on the higher fault, along which a movement of 900 feet or more was necessary to place Precambrian rocks adjacent to the lower part of the Morrison formation as shown in present exposures. Displacement on the lower fault is about 600 feet near Pinkham Creek, where the uppermost part of the Chugwater formation seems to have been thrust over the lower part of the Dakota. Where rocks of the Morrison formation comprise both walls of the fault near the surface the displacement is about 300 feet along the line of section $B-B^{\prime}$ to perhaps only 100 feet adjacent to the Independence Mountain fault. Thus an aggregate displacement of 1,500 feet or more seems indicated on the two faults, and in all probability the actual displacement was much greater.

The dotted line shown in section $B-B^{\prime}$ (pl. 12), representing the projected base of sedimentary strata, was drawn to indicate an aggregate displacement of about 2,000 feet along the faults beneath Dean Peak. Although no direct evidence for this amount of displacement was found, the character of folding indicated by the projection is in accord with the observed folding on Sentinal Mountain, section $A-A^{\prime}$ (pl. 12).

The eastern flank of Dean Peak is cut by a small fault that starts at the south as a vertical tear fault, and changes toward the north into a west-dipping reverse fault. It is cut off at the north by the Independence Mountain fault. Displacement on the small fault is a few hundred feet at the most, but the structure is noteworthy because it shows that the same segment of the fold was thrust both east and west.

The northward plunge of the axis of the anticline on the northern slope of Sentinal Mountain, and the southward plunge of the axis on Dean Peak indicate that the tear fault along Pinkham Creek marks a structural saddle along the crest of the faulted anticline. 
Whether this saddle is the cause or the result of the transcurrent movement is not known. The saddle may have formed before thrusting and thus localized the tear fault, or it may have resulted from predominant horizontal movements along the tear fault while the segments of the anticline both north and south were being thrust up along reverse faults of opposing dip.

\section{SYNCLINE EAST OF SENTINAT MOUNTAIN}

The Sentinal Mountain-Dean Peak anticline is bordered on the east by a syncline (fig. 34) that is much different on the opposing sides of the tear fault along Pinkham Creek. East of Dean Peak, the syncline is a broad open fold shown in section $B-B^{\prime}$ (pl. 12), with dips ranging generally from less than $10^{\circ}$ near the axis to as much as $40^{\circ}$ along the flanks. Some dips along the west margin are steeper, locally as much as $60^{\circ}$, but the asymmetry is not marked. The axis of the fold in this vicinity plunges southward at a low angle, probably between $5^{\circ}$ and $15^{\circ}$. East of Sentinal Mountain, the syncline is more closely compressed in section $A-A^{\prime}$ (pl. 12); the eastern limb dips $25^{\circ}-35^{\circ} \mathrm{SW}$., and the western limb dips as much as $60^{\circ} \mathrm{E}$. The axis of the syncline east of Sentinal Mountain also plunges southward, as shown by the divergence of the limbs of the fold in this direction. The lack of dip measurements along the western flank of the syncline makes it difficult to approximate the angle of plunge, but it probably is $15^{\circ}-20^{\circ}$. The axis of the syncline was displaced between $1 / 2$ and $3 / 4$ of a mile by movements on the tear fault along Pinkham Creek, and the segment of the syncline north of Pinkham Creek is at somewhat higher structural levels than the segment south of the creek.

The offset axis of the syncline, as well as the differences in structural level and closeness of folding across the tear fault along Pinkham Creek probably resulted from differences in relative directions of thrusting of the Sentinal Mountain-Dean Peak anticline. The part of the syncline north of Pinkham Creek is on the hanging-wall side of the main reverse faults in the bordering anticline, and was uplifted and displaced relatively west, but remained open. The part of the syncline south of Pinkham Creek, on the other hand, is on the footwall side of the reverse fault underlying Sentinal Mountain, and the relative eastward direction of thrusting on this fault tended to depress this block and compress the limbs of the syncline more closely.

\section{STRUCTURES ALONG THE FRONT OF THE MEDICINE BOW MOUNTAINS}

The sedimentary strata along the flank of the Medicine Bow Mountains in the southeastern part of the Northgate district dip $20^{\circ}-25^{\circ}$ $\mathrm{SW}$. and form the eastern limb of the syncline between the Medicine Bow Mountains and Sentinal Mountain. Dips in the beds are some- 
what lower north of a small transverse fault in sec. $23, T .11$ N., R. $79 \mathrm{~W}$. (pl. 12, section $A-A^{\prime}$ ), but the general structure adjacent to the mountain front is unchanged. The simple homoclinal dip of the beds is interrupted by faults that offset the contact between the sedimentary rocks and the underlying crystalline rocks, and stripping of the soft sedimentary rocks by erosion has resulted in steplike offsets of the mountain front along two such faults.

The largest of the faults trends slightly east of north across the front of the Medicine Bow Mountains near Government Creek in the southeastern part of the district. The basal contact of the sedimentary rocks shows a horizontal separation of about 1,100 feet across this fault, and erosion of the sedimentary rocks has produced a conspicuous offset of the mountain front. Exposures were too poor for the dip of the fault to be established with certainty, but the slight curvature of its trace indicates that it dips west at a fairly steep angle. No evidence was seen to indicate the type of movement on the fault, but it may be a reverse fault that resulted from the same compressional stresses that caused folding. An eastward-trending fault of very small displacement cuts the Precambrian rocks on the upthrown block of the larger fault. Although this minor fault has almost negligible displacement, it locally contains fluorspar of two ages.

Another steep fault cuts almost at right angles across the contact between the sedimentary strata and the crystalline basement rocks in the southern part of sec. $23, T .11$ N., R. 79 W., and the mountain front shows a steplike offset. The base of the sedimentary section shows a horizontal separation of about 600 feet across this fault, and the northern wall is displaced relatively east. This fault is in the hanging-wall block of a reverse fault that cuts obliquely across the mountain front, and it possibly may be a minor tear fault whose movement reflected differential displacement along the reverse fault. The steep fault follows the bottom of a small ravine where exposures are poor, and the presence of the fault could be determined only where distinctive horizons such as the basal contact of the sedimentary strata were displaced. In all likelihood the fault extends farther east than is shown on the geologic map (pl.12) and it may end against the reverse fault.

A southwestward-dipping reverse fault trends obliquely southeastward across the front of the Medicine Bow Mountains near the northeast edge of North Park (sec. 23, T. 11 N., R. 79 W.). The trace of the fault on the irregular topography indicates that it probably dips $30^{\circ}-40^{\circ} \mathrm{SW}$. toward the North Park basin. An isolated remnant of red shale, probably belonging to the Satanka(?) shale, is still preserved along the footwall of the fault, thus permitting a crude approximation of the amount of displacement. If the dips of the 
fault and the sedimentary beds along the line of section $A-A^{\prime}$ (pl. 12) are projected upward virtually unchanged, they indicate a possible maximum displacement of about 1,500 feet; a minimum displacement of less than 100 feet is possible, on the other hand, if the dip of the sedimentary strata on the hanging wall became progressively lower upward, and the base of the strata was close above present levels. The dotted line on section $A-A^{\prime}$ (pl. 12), indicating a projection of the base of the sedimentary rocks, shows a displacement of 350 to 400 feet, which seems a reasonable, although unsupported approximation.

The trace of the reverse fault northwest of the remnant of Satanka(?) shale is obscured by surficial debris and could not be located precisely; southeast of the shale remnant, however, the fault zone is marked by a silicified breccia zone that locally contains fluorite. The silicified zone dies out to the southeast, and the fault is lost in the middle of a large mass of quartz monzonite gneiss. Although the northwest end of the reverse fault is covered by alluvium, it apparently is cut off by a northeastward trending fault described below.

A northeastward-trending transverse fault intersects the northeast corner of North Park (secs. 22 and 23, T. 11 N., R. 79 W.), and the character of deformation is markedly different on the opposing sides of the fault. The southwest-dipping beds along the front of the Medicine Bow Mountains are cut off laterally by the fault, and the beds to the northwest are flat lying. The reverse fault along the front of the mountains also is cut off by the transverse fault, and no indication of it was seen to the northwest. The transverse fault is a vertical hinge fault, with almost no displacement near its southwest end, and with progressively larger displacements toward the northeast. The movement was much like that along the margin of a trap door, with the block to the southeast being raised relative to the block to the northwest.

Except for local steepening of dips and cross folding along the Independence Mountain fault, the structures northwest of the northeastward-trending transverse fault are broad open folds with small amplitudes. Adjacent to the transverse fault, the eastern limb of the syncline bordering Sentinal Mountain flattens abruptly and forms a structural terrace, which is well shown by the resistant basal conglomeratic sandstone unit of the Dakota group. Beds at the east end of the terrace are folded again near the Independence Moun-. tain fault. This folding may have been largely concurrent with the rest of the folding and faulting in North Park, or it may have resulted from drag along the Independence Mountain fault. The open character of folding persists to the northwest and west as far as Dean $542861-60-4$ 
Peak, so that the northeastward-trending transverse fault in the northeast corner of North Park, and the tear fault along Pinkham Creek together form a discontinuous boundary between areas of distinctive structural types. Most of the folds north of Pinkham Creek have a pronounced southward plunge, which may in part have been an original feature of the folds, but almost certainly was accentuated by cross folding below the Independence Mountain fault.

The northward-trending fault along the border between secs. 15 and 16 , T. 11 N., R. 79 W., is too poorly defined to be described adequately. Its presence is indicated by a discordance in the attitudes of beds, and by a smaller outlier of Sundance formation near an outcrop of Precambrian metamorphic rocks. The fault seems to dip steeply, but the direction of dip is not known, and in the absence of more definite evidence, it is shown on section $B-B^{\prime}$ (pl. 12), as being almost vertical.

FOLDS WEST OF THE SENTINAK MOUNTAIN-DEAN PEAK ANTICLINE

The bedrock underlying North Park between the Sentinal Mountain-Dean Peak anticline and the North Platte river is largely obscured by surficial deposits. The few areas with exposures indicate that the sedimentary rocks in this part of the Northgate district dip generally west and southwest toward the axis of the North Park basin, but that this general dip is disturbed by some subsidiary folds.

Exposures are best near Pinkham Creek, west of State Highway 125, (secs. 19 and 20, T. 11 N., R. 79 W.), where the upturned ends of several small folds crop out. These folds, comprising two small anticlines separated by a syncline, apparently are parts of a larger subsidiary anticline as shown in section $B-B^{\prime}$ (pl. 12). As suggested by the limited exposures, the double anticline becomes less complex to the south, where higher formations are involved.

Scattered outcrops of the more resistant beds in the Dakota group suggest that any other subsidiary folds on the flank of the North Park basin in the Northgate district are minor.

All the subsidiary folds west of the Sentinal Mountain-Dean Peak anticline appear to plunge southward. This plunge may reflect an original characteristic of the folds, but it seems likely that drag on the footwall of the Independence Mountain fault zone may have steepened the plunge significantly.

\section{FAULTS SOUTH AND SOUTHWEST OF SENTINAL MOUNTAIN}

Two concealed northwestward-trending faults are shown on the geologic map (pl. 12) south and southwest of Sentinal Mountain. The recognition and discussion of these faults are based largely on the work 
of D. M. Kinney (written communication, 1957) who has mapped the adjoining area south of the Northgate district.

The easternmost fault is required by the offset contact between the Benton shale and Niobrara formation, as shown in the scattered outcrops south of Sentinal Mountain (pl. 12). The fault could not be located closely in the field, nor could its trend be approximated closer than generally northwest. The direction of dip or type of displacement are not known.

The westernmost fault has been located somewhat more closely by Kinney (written communication, 1957). He reports an outcrop of probable Upper. Cretaceous arkosic sandstone a few hundred feet south of the area shown on plate 12, and almost due south of the shipping point of Northgate. This sandstone can be traced south of Government Creek where its approximate stratigraphic position is known. This position seems displaced relative to rocks exposed in scattered outcrops to the east and northeast. The trend of the fault is indicated in part by local discordance in attitudes of beds west of the North Platte River, and in part by a series of slight topographic depressions and minor vegetational differences that can be seen on aerial photographs.

\section{INDEPENDENCE MOUNTAIN FAULT}

The north end of the North Park basin terminates sharply against the Independence Mountain fault (pl. 12; fig. 34), a northward-dipping reverse fault that trends nearly eastward, transverse to the folds and faults formed earlier during the Laramide orogeny. The Independence Mountain fault has been traced for more than 18 miles from a point near Pearl, Colo. (Beekly, 1915, pl. 12; Walters, ${ }^{3}$ 1953, pl. 2) across the north end of North Park to the crest of the Medicine Bow Mountains near the east edge of the Northgate district. The hanging wall of the fault zone in the Northgate district is composed of Precambrian igneous and metamorphic rocks, which have been thrust over the folded late Paleozoic, Mesozoic, and early Tertiary sedimentary rocks in the North Park basin. The fault cuts out 10,000 to 15,000 feet of strata near the axis of the basin, a few miles west of the North Platte River (Beekly, 1915, p. 83), and the actual displacement was much greater, as Walters ${ }^{3}$ (p. 47) mapped an erosional window that cuts through the thrust block on the north slope of Independence Mountain, in which sedimentary rocks in the footwall block have been exposed as much as 4 miles north of the main trace of the fault. The maximum displacement cannot be estimated, as no sedimentary rocks are known on the hanging-wall block in the moun-

\footnotetext{
s Walters, R. F., 1953, Geology of the Independence Mountain area, North Park, Colorado: Wyoming Univ., M. A. thesis.
} 
tains north of the main trace of the Independence Mountain fault. zone.

Movement on the Independence Mountain fault zone clearly took place in early Tertiary time, as Precambrian rocks on Independence Mountain were thrust over the Coalmont formation of Paleocene age, and remnants of the White River formation of Oligocene age rest undisturbed across the fault zone at two places in the Northgate district. Movement took place early enough before deposition of the White River formation for erosion to remove the sedimentary rocks on the upthrown block, and to cut through an unknown thickness of the underlying crystalline rocks to form the irregular topography upon which the White River formation was deposited.

The dip of the fault zone is much lower where the Precambrian rocks on the hanging wall have been thrust over a thick section of sedimentary rocks, than where crystalline rocks predominate on both walls. The fault zone is nearly flat several miles west of the North Platte River, where Walters ${ }^{4}$ has mapped the erosional window in the thrust plate. Within the area studied in the present investigation, the dip of the fault zone is least just west of the North Platte River where it constitutes a single major break that dips $15^{\circ}-20^{\circ} \mathrm{N}$., and along which Precambrian metamorphic rocks have been thrust over all of the Paleozoic and Mesozoic formations and over part of the early Tertiary Coalmont formation. The fault appears to have the same general dip just east of the North Platte river, where the Precambrian rocks on Watson Mountain probably overlie Cretaceous strata. East of Watson Mountain the fault zone locally splits into. imbricate fractures that dip $35^{\circ}-70^{\circ}$ north as shown on section $C-C^{\prime}$ (pl. 2). The imbricate segment marks the westward limit of that part. of the fault zone along which Precambrian rocks constitute both walls: either at the surface or at shallow depths. The higher imbricate fractures are on trend with the main fault zone to the east, which dips. generally $50^{\circ} \mathrm{N}$.

The stratigraphic throw on the Independence Mountain fault just: west of the North Platte river exceeds 7,000 feet. The aggregate displacement across the imbricate segment of the fault zone near the east end of Watson Mountain probably is about the same, although here the main displacement is along the higher fractures in the zone, and the stratigraphic throw on the fracture marking the eastward extension of the main fault farther west is only a few hundred feet at most (pl. 12, section $C-C^{\prime}$ ). The shift in major displacement from lower to higher faults in the zone took place along a nearly vertical tear fault at the east end of Watson Mountain. Although evidence

\footnotetext{
4 Walters, R. F., 1953, Geology of the Independence Mountain area, North Park, Colo.: Wyoming Univ., M. A. thesis, pl. 2.
} 
is lacking for close estimates, the difference in tectonic transport of the blocks on the opposing sides of this tear fault seems to have been large. The block to the west stands much higher topographically and is composed entirely of Precambrian rocks which have been thrust over the Benton shale and younger formations, whereas the block to the east exposes remnants of the basal part of the sedimentary section which have been thrust over the middle and lower Mesozoic sedimentary formations.

The distribution of small remnants of the lower sedimentary strata within the imbricate fault zone just east of Watson Mountain reveals other structural complexities that seem best explained by a combination of cross folding and thrusting. The imbricate segment of the fault zone in this vicinity is divided laterally by a tear fault that cuts the largest rock slice in the fault zone into two subequal parts. The remnants of sedimentary rocks, including the Forelle(?) limestone and the lower part of the Chugwater formation, dip south along the south margin of the westernmost of these parts, and dip north along the north margin of the easternmost part. These opposing dips suggest that the lower part of the sedimentary strata may have been cross folded into an eastward-trending anticline along the line of structural discordance, probably during an early stage of faulting. This cross fold was broken by later thrusting, and the different blocks in the fault zone were displaced unequally along both thrust and tear faults. The fault block with the southward dipping remnants of sedimentary rocks seems to have been displaced somewhat less than the block to the east, and much less than the block to the west.

The Independence Mountain fault zone is very narrow, apparently comprising a single major break, for about $2 \frac{1}{2}$ miles from the imbricate segment near the east end of Watson Mountain to near the northeast corner of North Park (fig. 34). Although the fault was too poorly exposed for the dip to be measured over much of this length, its trace could be located within close limits. Dips of about $50^{\circ}$ were measured near the northeast corner of North Park, and comparable dips probably are characteristic over much of the rest of the segment. This inference has some support in the steep dips of those branch faults in the imbricate segment at the east end of Watson Mountain that are in line with the major break to the east.

The Independence Mountain fault zone splits into two major fractures near the northeast corner of North Park, and these breaks have been traced east as far as the crest of the Medicine Bow Mountains. A dip of $50^{\circ} \mathrm{N}$. was measured on the higher fault just east of the split in the fault zone, and a dip of $35^{\circ} \mathrm{N}$. was measured on the lower fault where it crosses Pinkham Creek. The traces of both branches 
of the fault on the irregular topography in the Medicine Bow Mountains to the east indicate that dips here generally are nearly $45^{\circ}$. A remnant of the lower sedimentary strata is exposed in a small fault sliver near the place the fault zone divides, but elsewhere the rocks within the zone are entirely of Precambrian age. The displacements on the two branches of the fault could not be measured, but no evidence was seen for structural complexities similar to those found in the imbricate segment at the east end of Watson Mountain, and the structural behavior of the rocks in this segment of the fault zone seems to be the same as in the segment adjoining it to the west.

\section{FAULTS OF PROBABLE LARAMIDE AGE}

Two faults of probable Laramide age cut the Precambrian gneisses on the Medicine Bow upland. Both of these faults are covered in part by undisturbed rocks of the White River formation, and thus they are clearly pre-Oligocene in age. Altered rocks along them are similar to altered rocks found along faults of known Laramide age, and the faults probably formed during the same orogeny. Neither the type of movement nor the amount of displacement could be determined on either of these faults.

The longest fault of probable Laramide age extends northwestward across the north-central part of the district. Both ends of the fault are covered by undisturbed rocks of the White River formation. The fault follows the bottom of a sharp, linear ravine for most of its length, and no good exposures were seen. The presence of the fault was determined by the discordance of rock units on the opposing walls of the ravine, and the displacement is large enough so that the sequence and thickness of rock masses cannot be matched across the fault. The trace leaves the botton of the ravine near the southeast end of the fault, and trends somewhat more southerly up a heavily wooded slope. This change in direction of the trace indicates a northeast dip, but exposures are too poor for the angle of dip to be estimated. Scattered float and exposures of hornblende gneiss near the southeast end of the fault show evidence of chloritic alteration similar to that noted at places along the Independence Mountain fault and other faults of known Laramide age.

Another fault of probable Laramide age trends east-northeast across the east-central part of the district (secs. 11 and 12, T. 11 N., R. 79 W.). The trace of the fault is marked by silicified fault breccia, by chloritic alteration of hornblende gneiss, and by a discordance in structure and rock type on the opposing sides. The fault dips about $25^{\circ} \mathrm{S}$. as determined by the trace of the fault on the irregular topography. The west end of the fault projects beneath rocks of the White River formation which are not offset. 


\section{POST-LARAMIDE STRUCTURES}

The Northgate district and nearby areas were subjected to at least one, and perhaps several periods of minor deformation during middle and late Tertiary time. Although the effects of the different periods of deformation are difficult to determine, the structures formed are of primary interest in considering the economic geology of the district, as the known commercial fluorspar deposits are localized along faults that are clearly younger that the White River formation, and are beveled by a high-level erosion surface believed to be late Cenozoic in age (see "Geomorphology," p. 385).

A mid-Tertiary period of deformation is suggested in the Northgate district by evidence of a reversal in direction of streamflow between Oligocene and late Miocene time, and by disrupted gradients along the base of some of the old stream valleys buried by the White River formation. The evidence for this period of deformation is not conclusive, however, as the indications are all susceptible to alternative explanations.

The best documented period of post-Laramide deformation followed deposition of the North Park formation in late Miocene and early Pliocene(?) time. Rocks in the North Park formation in southcentral North Park have been folded into a northwest-trending syncline that extends nearly across the park (Beekly, 1915, pl. 12). Although the effects are not as apparent, the rocks in the Northgate district were disturbed during the same period of deformation.

\section{POSSIBLE LATE OLTGOCENE OR MIOCENE DEFORMATION}

The apparent direction of stream drainage was reversed from generally southward-flowing before deposition of the White River formation in Oligocene time, to northward-flowing before deposition of the North Park formation in late Miocene or early Pliocene time (see "Geomorphology," p. 383). Minor deformation conceivably could have played some role in this reversal, but it is not necessarily required. The period of alluviation that resulted in deposition of the White River formation was due in part at least to an abnormally large supply of volcanic ash of foreign derivation, which greatly predominates over fragments of local rock types in the White River formation. Without evidence as to the source of this ash, and without data on the succession of geomorphic changes during and following alluviation, it is not possible to determine whether deformation, or some combination of alluviation and stream capture or headward erosion was responsible for the drainage reversal.

More specific evidence for local deformation following deposition of the White River formation is the disrupted gradient at the base of an old, pre-White River valley in the north-central part of the 
Northgate district. The dendritic pattern displayed by the White River rocks filling the branches of the old valley system indicate a general southeasterly direction of drainage, and it seems fairly certain that at one time it was integrated with the remnants of the preWhite River drainage system now marked by the remnants of the White River formation along Lawrence Creek and upper Camp Creek. The low point at the southeast end of the White River remnant in the north-central part of the district is near Camp Creek, at an altitude of about 8,340 feet. The nearest remnant of White River rocks on the "downstream" side of this low point is slightly less than a mile east, at an altitude of about 8,590 feet. Thus the isolated remnant of White River rocks in the north-central part of the district has been warped down at least 250 feet. This downwarp is in the central part of an area believed to have been warped up during the post-North Park formation period of deformation in Pliocene time (see following section), and thus it may represent an earlier period of deformation. The possibility exists, however, that the downwarp may have been a subsidiary effect of the Pliocene deformation.

\section{PLIOCENE WARPING}

The period of deformation in Pliocene time, following the deposition of the North Park formation, is well demonstrated in the southcentral part of North Park, where the North Park formation was folded into a northwestward-trending syncline, whose limbs locally dip more than $30^{\circ}$ (Beekly, 1915, pl. 12). The same period of deformation also warped the rocks in the Northgate district but the details are much more difficult to ascertain.

A general westward tilting of the North Park formation in the vicinity of the North Platte River is shown by the anomalously steep gradient at the base of the old valley now buried by the North Park formation. This old valley was broadly flaring in cross section, and evidently it had reached a more mature stage of geomorphic development than that represented by the present gorge of the North Platte River along the west margin of the Northgate district. The minimum present gradient at the base of this old valley, however, as measured from the southeast end of the old valley in sec. 14, T. 11 N., R. 80 W., to beneath the level of the North Platte River, is in excess of 150 feet per mile, which contrasts strongly with the gradient of about 20 feet per mile for the present North Platte River.

Evidence concerning the probable direction of drainage of the stream that deposited the volcanic gravels of the North Park formation in the northeastern part of the Northgate district suggests that this part of the district was tilted east. The gravels are clearly limited to an old valley that trended north to northwest along the northeast 
edge of the Northgate district. The east edge of the old valley is convex toward the east and is sharply defined by a steep slope that apparently formed a bluff on the outside of a bend in the stream course. The stream valley trended generally northeast to north in the southern part of the preserved remnant, and generally northwest in the northern part of the remnant. From the northern extremity of the gravels, the stream course appears to have turned west and southwest, and it probably joined the main northward-flowing late Miocene drainage system west of the present North Platte River near Quaintance Ranch (see "Geomorphology," p. 384).

The altitude of the base of the gravels ranges from about 8,660 feet near their northern limit, to about 8,860 feet, slightly less than 2 miles to the south. Conceivably tilting could have accounted for some of this gradient, but a northerly direction of streamflow is supported by the direction that bedding and crossbedding within the gravels are truncated. Assuming that most of the steeper crossbeds reflect foreset beds, and that channel fills and normally bedded sedimentary rocks were deposited nearly flat, the acute angles of intersection between truncated crossbeds and overlying channel fills or normal beds should open generally downstream. In addition, crossbeds are most likely to be truncated on their upstream ends, and to approach tangency with the underlying surface of deposition on their downstream ends. The exposures in the walls of a gravel pit near the Colorado-Wyoming State line were examined carefully with these criteria in mind. Many of the relationships observed gave no clear-cut evidence as to the direction of streamflow, a few suggested an easterly or southeasterly direction of flow, but most of those that could be classified clearly indicated a westerly direction of streamflow.

In contradiction with the field evidence, a statistical consideration of the dip elements in the gravels suggests a northeast to east direction of streamflow. Forty-two random measurements were made of dips of crossbedding and bedding in the gravel, sand, silt, and clay layers exposed in the walls of the gravel pit. These measurements were plotted on the lower hemisphere of a Schmidt equiarea net (fig. 35A). All but 2 of the measurements fell within $270^{\circ}$ of arc, extending from S. $70^{\circ}$ W., through north, to S. $30^{\circ} \mathrm{E}$. Although the points of dip are fairly well scattered through this arc, they are slightly more abundant in the northeast quadrant, and the distribution suggests a general northeast direction of streamflow. Dips taken on fine silt and clay beds that fill small channels in the gravel are even more contradictory of the field evidence. These beds, which probably were deposited horizontally, now dip $5^{\circ}-20^{\circ} \mathrm{E}$., and both the direction and amount of dip seem anomalous.

These differences in indicated directions of streamflow can be explained by an eastward tilting of the area along the northeast mar- 

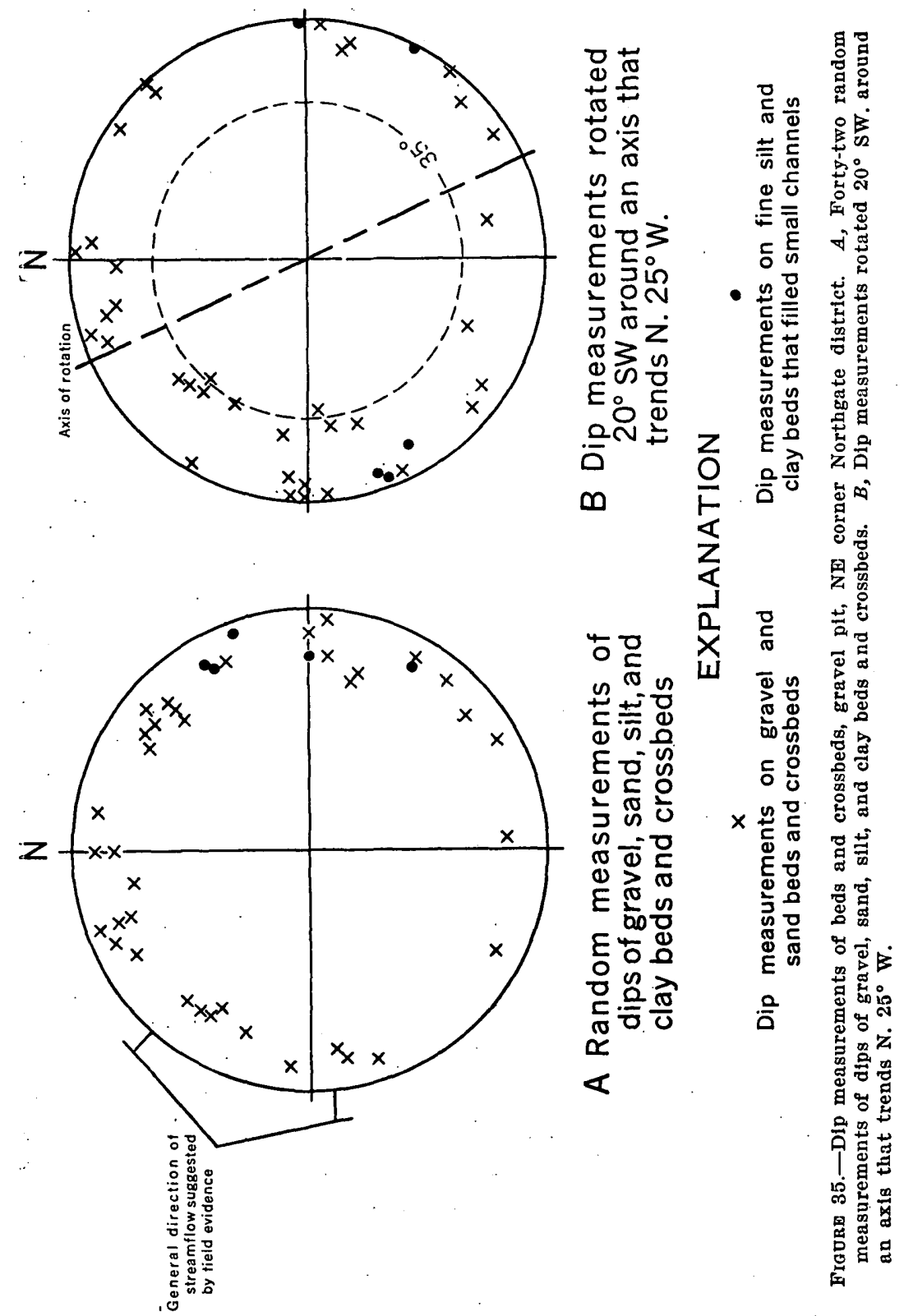
gin of the Northgate district after deposition of the North Park formation. An attempt was made to determine empirically the direction and amount of this warping by rotating the dip measurements back toward the original position suggested by field evidence along several axes of rotation. A general northwest trend for the axis of tilting was assumed by analogy with the northwest trend of the syncline involving the North Park formation in the south-central part of North Park, and a horizontal axis was assumed from the apparent broad character of the known warping. A tilt of about $20^{\circ}$ was considered probable from the maximum dip measured on the fine silt and clay beds in the gravel pit. A further assumption was made that the maximum angle of original dip that could reasonably be ascribed to the crossbeds was about $35^{\circ}$.

The measurements plotted on the Schmidt net in figure $35 A$ were rotated $20^{\circ} \mathrm{SW}$. for a succession of axis positions that ranged by increments of $5^{\circ}$ from $\mathrm{N} .10^{\circ} \mathrm{W}$., to N. $45^{\circ} \mathrm{W}$. The projections rotated around the axes trending N. $30^{\circ}$ W., N. $25^{\circ}$ W., and N. $20^{\circ}$ W., all seemed consistent with the field data. The clay and silt beds were nearly flat, the points of dip were concentrated in the southwest and northwest quadrants, and the maximum dips of crossbeds were about $35^{\circ}$.

The projection rotated around an axis trending N. $25^{\circ}$ W. (fig. $35 B$ ) was taken as typical of those that appeared consistent with field data. The general direction of streamflow, as indicated by the concentration of points of dip, is to the northwest; the maximum dip of crossbeds, within the limit of accuracy of measurement, is about $35^{\circ}$, and the silt and clay beds are nearly flat. The number of flat dips in the southeast quadrant suggests that a rotation of $20^{\circ}$ was not sufficient to compensate for the original tilting, but a rotation of $25^{\circ}$ around the same axis produced maximum dips of crossbedding of about $40^{\circ}$. An inelined axis of rotation might reduce some of the inconsistencies, but the character of the information did not seem to warrant further experimentation.

In view of the arbitrary and subjective nature of some of the assumptions, these empirical results cannot be regarded as more than crude approximations of the probable direction and amount of tilting. However, a general eastward tilt of $15^{\circ}-20^{\circ}$ along a northwestwardtrending axis at least provides a possible mechanism for explaining the contradictory data, and in this report it will be considered as the probable explanation.

\section{LATE TERTIART(?) FAULTS}

Four north- to northwestward-trending faults cut the Precambrian rocks and White River formation on Pinkham Mountain and the area to the southeast (fig. 34). These faults are definitely younger than 
the White River formation, and the largest of the faults is beveled by the high-level surface of low relief that marks the crest of the Medicine Bow Mountains in this vicinity (see p. 385). No evidence was seen in the Northgate district for determining the age of faulting closer than middle or late Tertiary, but Montagne (1953, p. 103; 1957, p. 39) and Walters ${ }^{5}$ have described similar northwestward-trending faults that cut the North Park formation north and northwest of Independence Mountain, $21 / 2$ to 15 miles west and northwest of the Northgate district. Thus it seems likely, although not certain, that the post-White River faults in the Northgate district formed during the Pliocene period of deformation.

The known commercial fluorspar deposits in the Northgate district. are localized along two of the late Tertiary (?) fault zones on Pinkham Mountain, and these faults have been studied in detail. The: other two faults of comparable age are poorly exposed and are virtually unprospected.

\section{FLUORSPAR-GERO-PENBER FAULT ZONE}

The westernmost of the late Tertiary (?) fault zones in the Northgate district trends slightly west of north from the vicinity of the Independence Mountain fault northeast of Dean Peak to near the center of the stock of intrusive quartz monzonite (pl. 12; fig. 34). Abundant fluorspar was deposited over much of the length of the zone, and it has been called the Fluorspar-Gero-Penber fault zone from the mine workings that have been developed along it. The fault zone cuts a small patch of White River formation near its south end, and it offsets the underlying Independence Mountain fault, (fig. 41). Just. north of the Independence Mountain fault, in the vicinity of the Gero and Penber mine workings, the younger fault zone cuts a tongue of intrusive quartz monzonite 400 to 500 feet wide. North of this tongue, the fault zone traverses an area where piecemeal stoping during the emplacement of the stock was particularly active, and the rocks now resemble a gross breccia, with many blocks of metamorphic rocks surrounded by irregular dikes of intrusive quartz monzonite. Beginning near the south end of the Fluorspar mine workings, the fault zone extends northward across the east end of the main body of intrusive quartz monzonite to near the center of the stock where it no longer can be traced. The north end of the fault zone possibly may offset sedimentary rocks of the White River formation, but exposures are poor and no displacement was apparent during field mapping.

The Fluorspar-Gero-Penber fault zone is nearly vertical over most of its length (see pl. 13). Displacement seems to have been minor and

\footnotetext{
5 Walters, R. F., 1953, Geology of the Independence Mountain area, North Park, Colorado: Wyoming Univ., M.A. thesis, p. 49.
} 
largely horizontal, with the western wall being displaced relatively north (right-lateral displacement). Most of the movement was concentrated on eastern and western marginal faults, and over most of its length the fault zone comprises two subparallel faults (see pl. 14) with the intervening rocks cut by many lacing fractures. The marginal faults approach one another closely near the middle of the fault zone, and near the crest of the small, westward-trending ridge north of the portal of the 200-foot level of the Fluorspar mine they actually merge near the surface into a single broken zone 15 to 30 feet wide. The marginal faults are distinct at depth beneath this broken zone, however, and on the 200-foot level of the Fluorspar mine they are separated by about 50 feet of much less fractured rock (pl. 13). The marginal faults diverge slightly to the north and south of the central segment of the fault zone; they are 250 to 300 feet apart near the north end of the Springer Pit near the north end of the fault zone, and they are 100 to 150 feet apart adjacent to the Gero mine workings near the south end of the fault zone.

Although the rocks within the fault zone are most broken where the marginal faults are close together, many fractures cut the intervening rocks even where the marginal faults are farther apart. Some of these subsidiary fractures are subparallel to the marginal faults, but others trend northeastward, diagonal to the fault zone.

Although it is difficult to estimate, a maximum aggregate displacement of less than 100 feet is postulated for the Fluorspar-Gero-Penber fault zone. The localization of movement within the fault zone apparently varied greatly, in places being concentrated largely along the walls of the zone. The character of the displacement is well shown in the lower level of the Penber mine where the hanging wall of the Independence Mountain fault is offset about 55 feet horizontally, with the west side displaced relatively north. Similar displacement is also apparent where the fault zone cuts the complex of dikes and blocks of metamorphic rocks between the Gero and Fluorspar mine workings; in some places a displacement of 20 to 40 feet is evident along each margin of the fault zone, although in other places, where contacts of the blocks of metamorphic rocks could not be located within 10 to 15 feet, no displacement could be discerned in the field. The abundance of fracturing provides the only clue to the amount of movement in those places where intrusive quartz monzonite comprises both walls of the fault zone. Even in the more broken marginal parts of the fault zone, the fault breccia is coarse with little finely granulated rock or gouge.

A shift in major displacement from one wall of the fault zone to the other is well shown on the 200-foot level of the Fluorspar mine (pl. 13). In the southern part of the workings the fracturing is 
strongest along the west vein; the east vein is marked by lacing fractures that locally are discontinuous. Between coordinates $3,800 \mathrm{~N}$. and 4,000 N. (pl. 13), however, a series of northeastward-trending gash fractures extend diagonally across the fault zone; to the north the east margin of the fault zone is strongly fractured and contains many open water courses whereas the west margin is much less broken.

\section{FLUORINE-CAMP CREEK FAULT ZONE}

The largest of the late Tertiary (?) fault zones in the Northgate district trends northwestward for about $21 / 2$ miles across the east end of Pinkham Mountain (pl. 12; fig. 34). Fluorspar is abundant along a large part of this fault zone, and several important mines have been developed on it. It is called the Fluorine-Camp Creek fault zone from the two groups of mining claims that cover most of its length. The fault zone dips steeply northeast, and the movement apparently was predominantly strike slip with the southwestern block being displaced relatively northwest (right-lateral displacement).

For the most part, the fault zone cuts the complex of Precambrian dikes and metamorphic rocks east of the main body of intrusive quartz monzonite, but it also offsets several channels filled with sedimentary rocks of the White River formation, and it dies out to the southeast in the large body of White River formation along Lawrence Creek. The fault zone is beveled by a late Cenozoic surface of low relief (the Medicine Bow surface of this report) along the summit of Pinkham Mountain, which presumably was cut after deposition of the North Park formation (see p. 385).

Natural exposures are few along the Fluorine-Camp Creek fault zone, and the general course is marked chiefly by the abrupt terminations of the offset dikes of intrusive quartz monzonite. The zone can be examined in detail only in mine workings, and in the few prospect pits and trenches along it that penetrated the thick overburden. Where exposed, the fault zone ranges from a few feet to 70 feet in width, and consists of highly brecciated rock cut by a few persistent fractures. The walls are commonly marked by well-defined fault surfaces, although in places the hanging wall of the zone is indefinite and brecciated rock grades into unbroken wallrock. The bounding faults and persistent fractures within the zone generally dip between vertical and $70^{\circ} \mathrm{NE}$; in places the fractures dip fairly uniformly, but elsewhere they show many local irregularities. The dip probably averages about $80^{\circ} \mathrm{NE}$. Most of the rock fragments in the fault zone are less than a foot in diameter. Finely comminuted rock and gouge are not abundant, however, and are limited for the most part to the persistent fractures that bound and cut the zone. Most of the slickensides and grooves on the persistent fractures are 
nearly horizontal, although locally they plunge steeply in several directions.

Minor fissures extending generally northward out of the fault zone into the hanging wall are fairly common; similar fissures extending southward into the footwall are less common, although they are locally prominent. None of these subsidiary fissures could be traced far from the walls of the mine workings, and most of them seemed to become weaker and some to die out within a few tens of feet from the margins of the main fault zone.

As the fault zone is followed northwestward it tends to be deflected west along local bends that give the zone as a whole a slightly sinuous trace (pl. 15). At least two of these deflections are marked by branch faults and sheared rock that persist northwestward into the hangingwall block of the succeeding segment of the fault. These deflections and their attendant fissuring are economically significant, and at one place at least the fractured hanging wall contains a large deposit of low-grade fluorspar (see p. 405).

The most apparent deflection and hanging-wall split begins about 1,800 feet southeast of the Camp Creek mine where the fault zone forks into two main branches; the branch with the greater displacement continues northwestward about on trend with the fault zone to the southeast, whereas the other branch diverges to the west and passes through the Camp Creek mine (pl. 15). The area near the split was so poorly exposed when the fieldwork was done that almost no details of the fracturing were seen, and only the general trends of the branches could be determined.

The other deflection of the fault zone known to be marked by many hanging-wall fractures is near the south end of the Fluorine mine (pls. 12,15). The deflection is apparent from surface exposures, and a hanging-wall split can be traced for more than 200 feet northwestward from the bend about on trend with the segment of the fault zone to the southeast. Although surface exposures are poor northwest of this bend in the fault zone, diamond-drill holes put down by Ozark-Mahoning Co. show that the hanging wall of the fault zone is highly fissured along trend from the bend at least as far as the Old Baker pit (pl. 15), and that many of these fissures contain fluorspar in significant concentrations. Whereas the main fault zone dips $80^{\circ}-85^{\circ} \mathrm{NE}$. in the vicinity of the Bureau of Mines shaft and the Old Baker pit, a drill hole that intersected the bend in the fault zone showed that the zone here dips only $60^{\circ}-65^{\circ} \mathrm{NE}$. This flattening of the dip within the deflected segment may be of local significance only, but it may characterize some of the other bends as well. 
The more northward-trending diagonal hanging-wall fissures seem to be most abundant in the vicinity of the deflected segment of the fault zone, and in the fractured hanging-wall block immediately northwest of the deflected segment. These may account for some of the fissures found by Ozark-Mahoning Co. in their diamond-drill holes, but others may mark subparallel continuations of the fractures that project northwestward along trend from the segment of the main fault southeast of the bend.

The Fluorine-Camp Creek fault zone was interpreted to have had normal fault movement in the preliminary reports that have been published on the Northgate district (Steven, 1953, 1954, 1956). This interpretation was based largely on the relations exposed in the Bureau of Mines shaft where an apparent downdip movement of somewhat more than 100 feet seemed indicated (Steven, 1954). Subsequent mine development has shown that a predominantly strike slip movement is more in accord with the evidence.

Revisions in the geology of the area adjacent to the Fluorine-Camp Creek fault zone made in 1954 and 1956 following extensive opencut mining operations and diamond drilling by Ozark-Mahoning Co. (pl. 15) have shown that all of the Precambrian rock units are displaced laterally across the fault zone, and with the exception of the branch fault extending through the Camp Creek mine, the movement seems to have been right-lateral with the northeastern block displaced southeastward. The fault branch through the Camp Creek mine apparently had left-lateral displacement (pl. 15), so the wedge of rocks between the fault branches has been displaced northwestward relative to the adjacent blocks. The contacts of most of the Precambrian units dip steeply so the separation of 200 to 250 feet shown on the geologic map (pl. 15) may closely approximate the actual amount of displacement for most of the length of the fault.

The bodies of White River formation cut by the fault zone do not show offsets comparable to those of the Precambrian units. These inconsistencies probably reflect in various degrees the effect on the apparent fault displacement of the irregular topography beneath the White River formation, the flat contact beneath many of the remnants of the White River formation, and the vagaries of subsequent erosion. More important, thin remnants of White River formation on opposing sides of the fault zone northwest of the Old Baker pit, and the comparable widths of White River formation across the fault where it cuts deeper filled channels rule out any large vertical component of movement. The two remnants of White River formation near the northwest end of the fault zone (pl. 15) are limited to the footwall of the fault so that locally at least the zone shows reverse fault relationships. 
The abundant nearly horizontal slickensides and grooves along the persistent fractures in the fault zone also indicate preponderant strike-slip movement. Local steeply dipping slickensides show that the movement was complex, however, and the ratio of vertical to horizontal displacement probably varies from place to place.

The fracture pattern shown by the subsidiary fissures:along the fault zone is consistent with the interpretation of right-lateral strikeslip movement. The more northward-trending fractures that extend diagonally for short distances into the walls of the fault zone would thus be diagonal tensional cracks or gash fractures opened by friction between the opposing walls. These apparently are most abundant in the vicinity of bends in the fault where longitudinal hanging wall fissures also are abundant; here they probably reflect the shift in displacement from the trend of one straight segment of the fault to another.

\section{MINOR FAULTS OF LATE TERTIARY(?) AGE}

A small northwestward-trending fault that appears to be an echelon continuation of the Fluorine-Camp Creek fault zone cuts the White River formation and Precambrian rocks just east and southeast of Camp Nelson (pl. 12). Presence of the fault is indicated by offsets of the contact between the White River formation and the Precambrian rocks along a line of minor topographic depressions, the displacement of several rock units of Precambrian age across the trend of the fault, and by several small exposures of breccia. The nearly straight trace of the fault across irregular topography indicates that the dip is steep, but no measurements were made. The map pattern (pl. 12) indicates that the fault may have had right-lateral strike-slip movement similar to that on the Fluorine-Camp Creek fault zone, although a proper combination of normal faulting and subsequent erosion could have produced the same rock distribution. The offset Precambrian rock units could not be matched closely enough across the fault to indicate which type of movement is the more likely.

The small fault that crosses Pinkham Creek at the east end of Kings Canyon apparently dips steeply northeast. Exposures are so poor that the fault could not be traced accurately, nor could the amount or direction of displacement be determined with confidence. The presence of the fault is indicated by an offset dike near the northwest end of the fault, and by an anomalously linear segment of the marginal contact of the White River formation in the vicinity of Pinkham Creek. The offset dike suggests that the fault may have had rightlateral strike-slip movement, but this is not borne out along the southern part of the fault where White River rocks seem to. have been faulted down against Precambrian rocks.

$542861-60-5$ 


\section{GEOMORPHOLOGY}

Parts of erosion surfaces of early and middle Tertiary age are preserved beneath remnants of the White River (early Oligocene) and North Park (late Miocene and early Pliocene?) formations near the Northgate district, and the summit of the Medicine Bow Mountains in this vicinity is marked by a high-level surface of low relief that bevels structures that were formed during the period of deformation that followed deposition of the North Park formation. The main fluorspar deposits in the Northgate district were deposited following this same period of deformation, and the Cenozoic geomorphic history was considered in detail in an attempt to determine the geologic environment in which these deposits were formed. The results of this investigation have been reported in detail in a separate report on the Cenozoic geomorphic history of the Medicine Bow Mountains near the Northgate district (Steven, 1956), and are presented here in a more generalized form.

\section{PRE-WHITE RIVER EROSION SURFACE}

The oldest geomorphic elements of Cenozoic age recognized in the Northgate district are remnants of early Tertiary valleys preserved beneath the tuffaceous sediments of the White River formation. The local character of this surface can be reconstructed from the distribution of the White River formation and the shape of the valleys that it fills. These indicate that the pre-White River surface was hilly, with local relief of 500 feet or more within a quarter or half a mile, even in the headwater areas where the topography was most subdued. This local topography may not have been typical of the region as a whole as the remnants of White River formation are flanked on both sides by higher ground of Precambrian rocks, and the Northgate district seems to have occupied a low area where the topography should have been most mature.

The dendritic pattern displayed by the valley remnant indicates that the early Tertiary streams in the Northgate district flowed generally southward. The valleys drained into the area now occupied by North Park and reached local levels not far above the present floor of the basin. The Precambrian cores of the Medicine Bow Mountains and the Park Range which flank North Park stand higher than the remnants of White River formation in the Northgate district, and it seems quite probable that the southward-flowing drainage in early Tertiary time was confined to an ancestral North Park and may have been integrated with a drainage system in the Middle Park area. Montagne and Barnes (1957, p. 56) describe about 400 feet of White River in the North Park syncline in south-central North Park, and 
Lovering (1930, p. 73) and Richards ${ }^{6}$ report rocks of Oligocene age that probably are correlative with the White River formation from Middle Park.

Volcanic ash, derived from sources outside the Northgate district, filled the early Tertiary valleys and may have completely covered the old terrain to form the White River formation. This formation consists largely of fine ashy beds; arkosic sands and gravels of local derivation comprise an anomalously small fraction considering the steepness of the topography at the time of deposition. Knight (1953, p. 69) believes that the lack of coarse debris indicates low relief on the interfluve areas. A more important reason may have been that a sudden large supply of volcanic ash so overloaded the streams that they rapidly aggraded their courses and were unable to erode bedrock.

Remnants of the White River formation are found near the crest of the Medicine Bow Mountains at several places in the Northgate district, and the formation may at one time have covered all of the present mountains in this vicinity. The cover had to be thick enough to accommodate most of the erosion and geomorphic changes, including a complete reversal in the direction of stream drainage, that took place during the latter part of Oligocene and much of Miocene time.

\section{PRE-NORTH PARK EROSION SURFACE}

Important changes in the topography of the area near the Northgate district took place in later Oligocene and much of Miocene time between deposition of the White River formation and the development of the surface upon which the North Park formation was deposited. The general direction of streamflow was reversed from southward to northward, and a terrain was developed that was in many respects similar to the present one, including a topographic basin in the North Park area drained by northward-flowing streams superimposed across a partly exhumed surface of earlier Tertiary age.

These changes were accompanied by only moderate erosion near the Northgate district, as no streams cut through the cover of White River rocks to present levels until the valleys now filled with the North Park formation were established. Elsewhere in the Rocky Mountains of northern Colorado and southern Wyoming, however, erosion cut deeply during this interval, and fluviatile sediments and volcanic ash were deposited widely to form the Browns Park formation of Miocene(?) age. McGrew (1951, p. 55-56) has described this formation in the Saratoga basin, 35 to 40 miles northwest of the Northgate district.

'Rlchards, Arthur, 1841, Geology of the Kremmling area, Grand County, Colorado: Michigan Univ. Ph. D. thesis, p. 31. 
The main stream on the pre-North Park surface left the ancestral -North Park basin through a narrow valley near where the present North Platte River leaves North Park, and both the present valley and the valley of Miocene age trend northwestward for 30 to 35 miles across basement rocks of Precambrian age to the Saratoga basin in Wyoming. The pre-North Park valley was broad and flaring in cross section however, and was much more mature than the youthful gorge that now confines the North Platte River.

A topographic basin in the North Park area before the deposition of the North Park formation is indicated by the widespread distribution of this formation in south-central North Park. As mapped by Beekly (1915, pl. 12) and described by Montagne and Barnes (1957, p. 56), the bedding in the North Park formation is nearly parallel to the basal contact and the formation apparently was deposited on a surface of low relief. This broad basin area was drained through a valley now marked by the wind gap along the northern flank of Watson Mountain and presumably the basin surface was graded to the resistant threshold of this exit.

A smaller remnant of the pre-North Park surface is preserved beneath volcanic gravels of the North Park formation that partly fill an old valley near the northeast corner of the Northgate district. This valley apparently was localized in the area underlain by soft White River rocks and occupied a partly exhumed and modified valley of earlier Tertiary age. The valley of pre-North Park age truncates some of the minor buried ridges of Precambrian rocks beneath the White River formation, but the stream course was not deeply incised.

The stream valley in which the gravels of the North Park formation were deposited near the northeast corner of the Northgate district apparently is arcuate toward the east and impinges against the east margin of the partly exhumed valley of early Oligocene age containing the White River formation. The exhumed valley wall has not been breached by any younger valley system, and apparently during the Miocene the drainage bent sharply west near the northeast corner of the Northgate district following a tongue of soft White River rocks along much the same course that now is followed by Camp Creek in the north-central part of the district. This tributary probably joined the northwestward-trending main stream of Miocene age near Quaintance Ranch, near the northwest corner of the Northgate district.

In late Miocene and early Pliocene(?) time the fluviatile material of the North Park formation was deposited over wide areas in the North Park basin in Colorado and the Saratoga basin in Wyoming, and in a long, northwestward-trending valley between 
them (Montagne, 1957, p. 39). The maximum depth of fill in the Northgate district is not known, but Montagne 1957, p. 39) postulates an aggregate thickness in the Saratoga Valley not far northwest of the Northgate district of 3,000 feet or more. Such a thickness: would have been sufficient to cover all the present surface of the Northgate district.

\section{MEDICINE BOW SURFACE}

A surface of low relief, called the Medicine Bow surface (Steven, 1956), comprises much of the broad summit of the Medicine Bow Mountains and is manifested by accordant ridge crests and upland areas of low relief. Some of the flat summit areas are extensive, and even in an area as well dissected as the Northgate district, virtually unmodified remnants from several thousand feet to a mile or more in diameter still exist. In detail, the surface consists of a low rolling topography and a well-integrated drainage system. The total relief within the Northgate district is about 2,000 feet, ranging from an altitude of about 8,200 feet near the North Platte River to almost 10,200 feet along the crest of the Medicine Bow Mountains near the southeast corner of the district. Local relief ranges from a few feet to 400 feet within a mile.

Evidence from the Northgate district (Steven, 1956, p. 46-52) suggests that the Medicine Bow surface in this vicinity is of composite origin. The hilly topography of early Tertiary age (the pre-White River surface) was buried in early Oligocene time by the White River formation, which apparently covered the area to heights above those of the present surface. The White River formation was locally stripped from the area by late Miocene(?) time, when the streams cut approximately the same relative depths as the streams of early Tertiary age. Those parts of the pre-Tertiary rocks that projected above the White River formation at this time undoubtedly were reduced somewhat, but the evidence is too fragmentary for the pre-North Park surface to be reconstructed in more than local areas. This period of erosion ended with the deposition of the North Park formation, which probably completely covered the older terrain in the Northgate district. Warping and faulting followed deposition of the North Park formation and deformed a widespread area around the Northgate district, undoubtedly disturbing the earlier surfaces. The commercial fluorspar in the Northgate district was deposited in two of the faults formed at this time. Subsequent erosion stripped off the upper part of the North Park formation, and reduced the exposed basement rocks to the state of low relief now represented by the Medicine Bow surface. This surface bevels the Fluorine-Camp Creek vein zone and thus formed subsequent to mineralization. In places, par- 
ticularly in the northwestern part of the Northgate district, this surface is nearly coincident with and includes remnants of the earlier surfaces, but throughout much of the district the late Tertiary period of erosion significantly modified the exhumed terrains and destroyed all topographic evidence of the post-North Park formation period of deformation.

\section{PLEISTOCENE REJUVENATION}

The present gorge of the North Platte River north of North Park and the incised lower courses of the adjacent tributaries resulted from accelerated erosion following rejuvenation, which probably began with the widespread uplift of the Rocky Mountain region between late Pliocene and middle Pleistocene time. The broad basin of North Park is graded to the threshold of the North Platte gorge between Watson Mountain and Independence Mountain, and it evidently resulted from rapid erosion of the soft sedimentary rocks in North Park during the same geomorphic cycle.

\section{MINERAL DEPOSITS}

Fluorspar, the main valuable mineral commodity in the Northgate district, overshadows all other commodities combined in value of total production. Although fluorspar was deposited during two widely separated periods of mineralization, only the younger deposits have produced large quantities of ore or contain significant known reserves.

Small concentrations of copper minerals are widely scattered in the Precambrian rocks, chiefly in pegmatite bodies. A few copper deposits have been developed by underground workings, but no production has been reported.

Vermiculite deposits in the Precambrian rocks near the northwest corner of the district have been prospected by opencuts and limited underground workings. None of the deposits seen was large, but some appeared to be potential sources of small quantities of commercial-grade vermiculite.

\section{COPPER DEPOSITS}

Most prospecting near the Northgate district prior to 1915 was stimulated by the widespread copper showings, and at one time the general region was known as the Copper Ridge mining district. Most of the copper is in pegmatite bodies in the gneiss complex, and natural exposures generally consist of green malachite and chrysocolla stains on weathered surfaces. The malachite and chrysocolla were derived from minor, widely scattered chalcopyrite, which locally is in small concentrations making up several percent of the rock. Generally, however, chalcopyrite is sparse, and most pegmatite bodies are vir- 
tually barren of copper. The local copper-rich masses rarely exceed a few feet in diameter, and they constitute only a small part of the associated pegmatite body.

Chalcopyrite and secondary malachite also were observed locally along the contacts of the intrusive quartz monzonite stock, and at one place in the core of Precambrian rocks in Sentinal Mountain they occur in the breccia along a minor Laramide fault. The copper minerals in these places generally are in even lower concentration than in the earlier deposits in the gneiss complex.

Although small prospect pits are abundant, only three copper deposits near the Northgate district have been developed to any extent. The Kings Canyon mine, along Pinkham Creek near the east margin of the district, is developed along a narrow, discordant pegmatite lens. which ranges from a few inches to about $21 / 2$ feet wide, and is nearly 300 feet long (fig. 36). Two tunnels, vertically about 100 feet apart, expose the full horizontal length of the lens. Chalcopyrite and molybdenite are the primary ore minerals, and they occur chiefly in scattered local concentrations. Even where most abundant, the sulfide minerals do not exceed 10 percent of the pegmatite, and away from the local concentrations they seem to comprise only 1 percent or less of the rock.

The Badger prospect, in sec. 2, T. 11 N., R. 80 W., is in an irregular pegmatite body surrounded by hornblende gneiss. The prospect is caved and inaccessible, but the size of the dump indicates that there may have been as much as 100 feet of underground workings. Secondary chrysocolla and malachite were the only copper minerals found on the dump, and these fill fractures and cavities in the pegmatite. According to long-time residents of the area, the ore occurred in scattered "kidneys" that were widely separated.

The Village Belle mine, about a mile east of the Northgate district, develops a poorly exposed pegmatite by a shaft. The workings are old and inaccessible, but specimens on the dump show secondary green copper stains on pegmatite, and it is probable that the occurrence here is similar to that seen in other copper-bearing pegmatites in the Northgate district.

\section{VERMICULITE DEPOSITS}

Vermiculite is exposed in several prospect pits and mine workings along the west margin of the Northgate district, and outcrops of similar or related material were noted at many widely scattered places throughout the Precambrian terrain of the district. The most extensive mine workings are in secs. 26 and 34, T. 12 N., R. 80 W., west of the North Platte River and outside of the area mapped in detail. Two of these deposits, the Quaintance No. 1 deposit and 


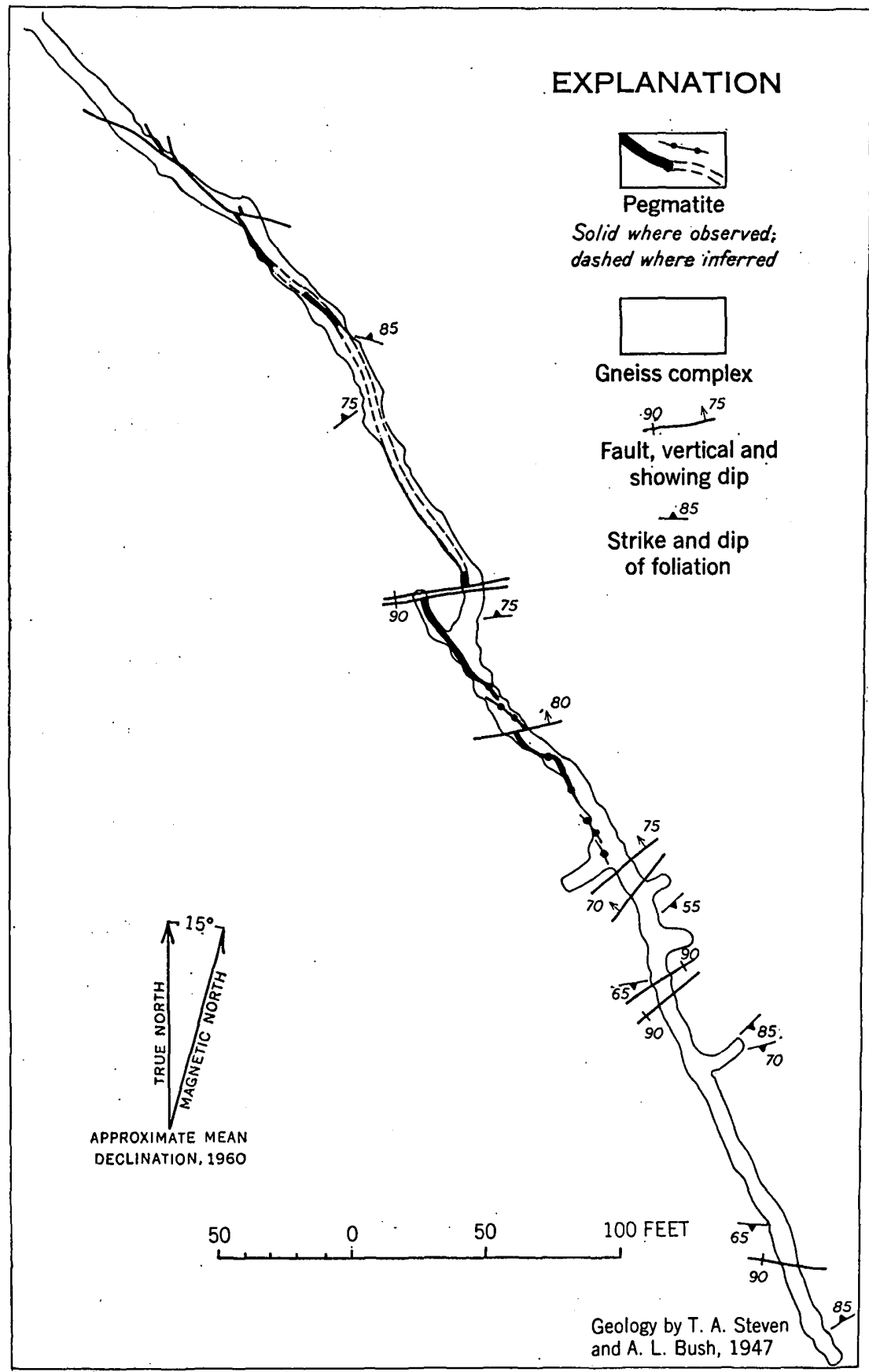

Fradri 36.-Geologic map of the lower adit, Kings Canyon mine. 
the Riggs or Fourney deposit, have been described briefly by both Goldstein (1946, p. 12-17) and Bush (1951, p. 340-342)." Similar, but less well developed deposits occur in the adjacent area east of the North Platte River, in secs. 25, 26, 35, and 36, but only one of these, the Resort deposit, has been described previously (Bush, 1951, p. 342$)$.

The vermiculite deposits in the Northgate district are believed to have formed as a local manifestation of the general metasomatic transformations that occurred in the gneiss complex following dynamothermal metamorphism (Steven, 1957a). The vermiculite deposits are all associated with ultramafic masses (hornblendite, massive chlorite, or serpentinite) that are either near or cut by pegmatite bodies. Vermiculite is only one of a series of reaction products that formed from the ultramafic rocks under the influence of the pegmatitic fluids; and most commonly it occurs as irregular bodies within hornblende-rich borders around serpentinite or massive chlorite pods.

The ultramafic masses in the gneiss complex range from small clots of hornblendite a few feet to a few tens of feet across, to pods of massive chlorite 10 to 50 feet in length and a few feet to 30 feet in width, and masses of serpentinite or altered serpentinite as much as 300 feet in length and 75 feet in width. Local segregations of hornblendite within normal hornblende gneiss form small bodies that are widely scattered throughout the gneiss complex. The chlorite and serpentinite masses, on the other hand, are most abundant near the west margin of the district where they form podlike masses separated from the surrounding hornblende gneiss by irregular borders of hornblendite that range from 1 foot to about 10 feet in thickness. Most of the serpentinite masses are partly altered to chlorite, and probably many of the massive chlorite bodies were once serpentinite.

In the vicinity of pegmatite masses the small hornblendite segregations in hornblende gneiss generally have a distinctly coarser grain than those farther from pegmatite, and commonly they are generally altered to shiny black biotite. Minor concentrations of nearly pure biotite were seen in several localities, and in a few places the biotite was somewhat altered to chlorite. No commercial-grade vermiculite was seen at any of these localities, however.

The massive chlorite and serpentinite bodies and their hornblendic border zones, on the other hand, are commonly highly altered near the pegmatite bodies. A serpentinite core generally is either altered irregularly to chlorite, or is surrounded by an irregular envelope of chlorite. This is followed by a tremolite- or actinolite-rich zone, and in turn by a biotite or vermiculite zone. Red garnets are common in the outer zone in places where biotite is the chief micaceous mineral (fig. 37), and locally the garnets attain diameters of 1 to 2 inches. 
The vermiculite-biotite zone is generally surrounded by unaltered hornblende gneiss or hornblendite, although locally the country rock contains abundant biotite or chlorite.

Although the vermiculite-biotite zone generally seems to replace the hornblendite border of an ultramafic pod, in some places it has formed within the surrounding hornblende gneiss and in other places it is associated with the chlorite or serpentinite in the core (figs. 38 and 39). The vermiculite-biotite zone is generally separated from chlorite or serpentinite in the core by a rim of tremolite-actinolite (fig. $39 B$ ).

Alteration of some ultramafic pods progressed beyond the zoned arrangement typical of the vermiculite deposits, an converted large masses of ultramafic rock to several talc-muscovite-quartz rocks. Many of these talcose bodies show pseudomorphs of minerals present in an earlier zonal arrangement, and many contain irregular residual aggregates of minerals common in the zoned deposits.

The origin suggested for the vermiculite deposits in the Northgate district is similar to the origin suggested by others for vermiculites in this region in the Rocky Mountains. Both Goldstein (1946, p. 17) and Bush (1951, p. 340-341) interpreted the vermiculite deposits near Quaintance Ranch as having formed by alteration of hornblendic rocks under the influence of pegmatitic solutions. According to Hagner $(1944$, p. 17-18), the vermiculites in southern Wyoming formed by the action of hydrothermal solutions from granite pegmatites on bodies of serpentinite, hornblendite, and other hornblende-bearing metamorphic rocks.

Zonally arranged transformation products are common in other areas where vermiculite deposits were derived from serpentine bodies. According to Hagner (1944, p. 17), hydrothermal alteration of serpentinite bodies in Wyoming resulted in distinct zones composed of nearly pure bands of actinolite, anthophyllite, vermiculite, chlorite, and talc. Phillips and Hess (1936, p. 341-343) describe several examples of mineral zoning where hydrothermal solutions derived from "felsic irruptives" have reacted with serpentine masses. The zoning exhibited by the Northgate vermiculite deposits is closely similar to their "higher temperature types."

\section{FLUORSPAR DEPOSITS}

Two distinct types of fluorite-bearing deposits are found in the Northgate district; evidence is not conclusive but the marked difference in appearance and occurrence suggests that they are unrelated. Small bodies of silicified breccia containing coarsely crystalline purple, green, and white fluorite complexly mixed with finely granular quartz crop out sporadically along the Independence Mountain fault 
GEOLOGY AND FLUORSPAR DEPOSITS, NORTHGATE DISTRICT 391

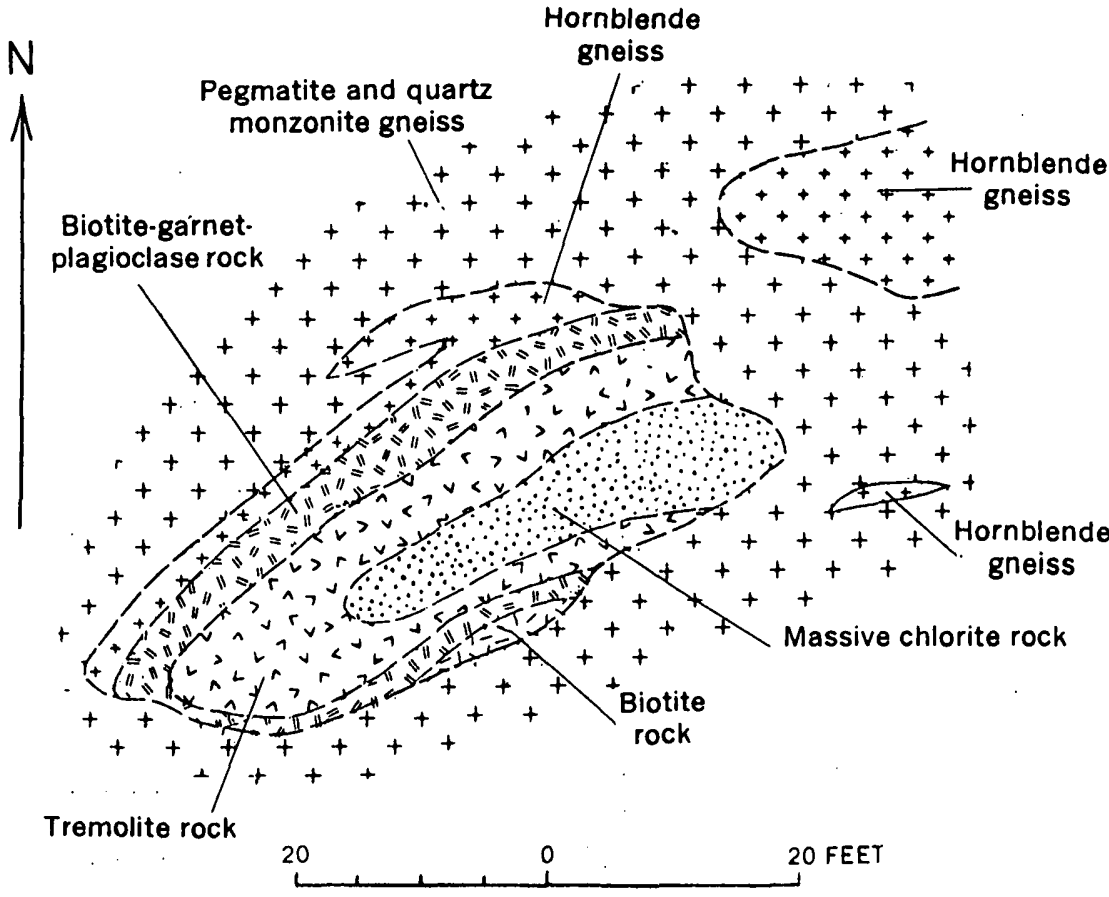

Figurb 37.-Sketch map of an altered ultramafle mass in sec. 36, T. 12 N., R. 80 W.

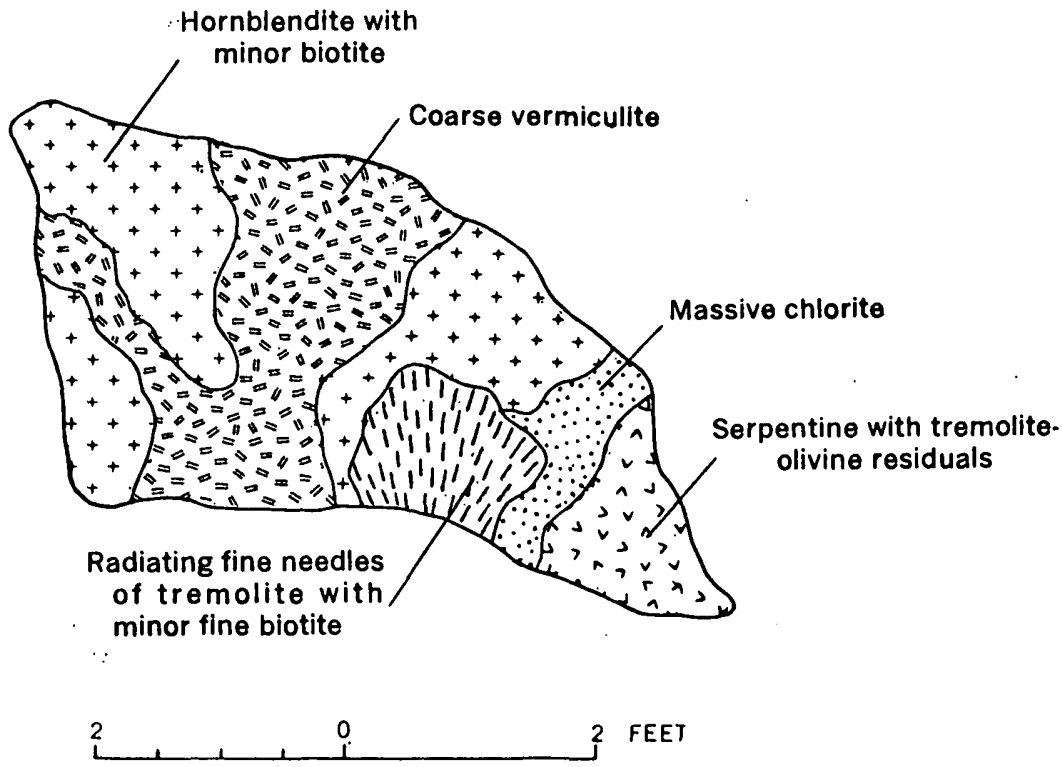

FIGURE 38.-Sketch of the wall of a prospect pit in the south-central part of sec. 26, T. 12 N., R. 80 W. 


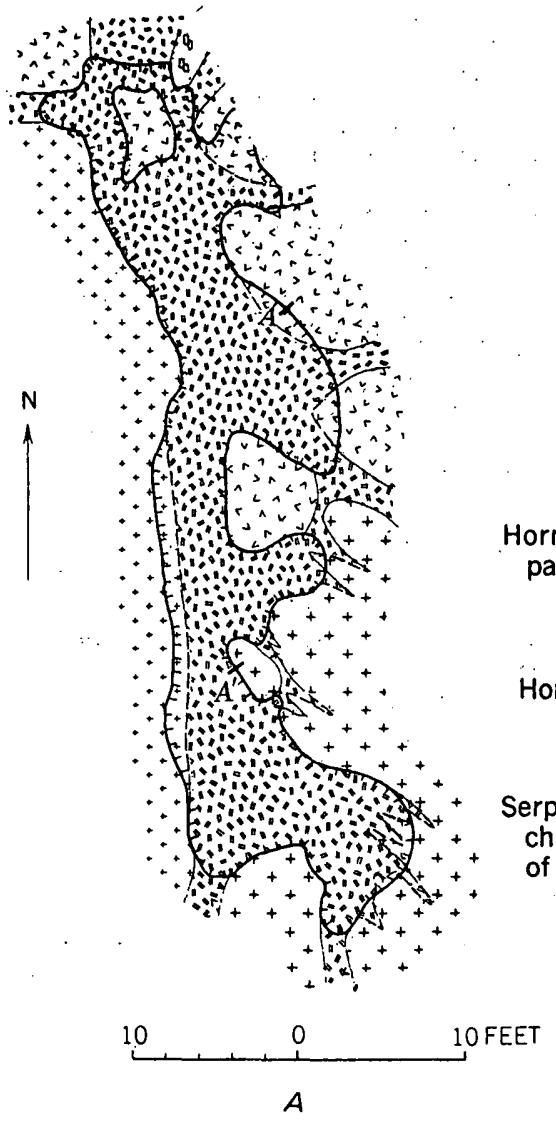

GEOLOGIC MAP OF PROSPECT PIT

\section{EXPLANATION}

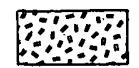

Vermiculite

$\mathrm{b}_{\mathrm{b}} \mathrm{b}$

Biotite-plagioclase pegmatite

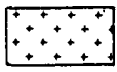

Hornblende gneiss and hornblendite, partly altered to biotite and chlorite

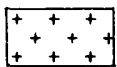

Hornblende gneiss and hornblendite

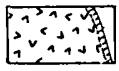

Serpentine largely altered to massive chlorite, with a marginal reaction rim of tremolite and actinolite (shown on B)

Edge of opencutt

\section{Contact}

Dashed where approximately located
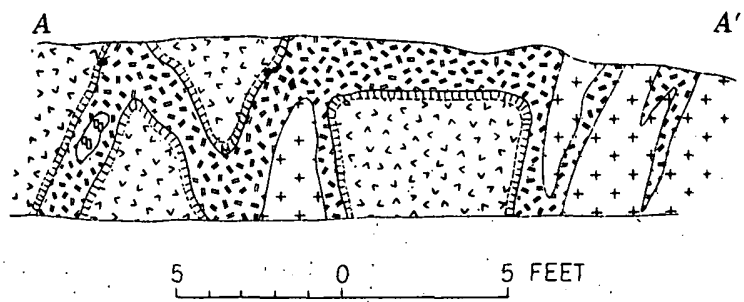

$B$

IDEALIZED SKETCH OF SEGMENT $A \cdot A^{\prime}$ OF EAST WALL OF PROSPECT PIT

Figure 39.-Quaintance vermiculite prospect sec. 25, T. 12 N., R. 80 W., $A_{\text {; }}$ Geologic map of prospect pit. $B$, Ideallzed sketch of segment $A-A^{\prime}$ of east wall of prospect pit. 
system, and other Laramide faults. The fluorite is an integral part of the fault breccia and apparently was deposited while the enclosing fault was still active. Known commercial deposits containing fluorite consist of crustified veins and breccia fillings along the lateTertiary ( ?.) faults on Pinkham Mountain; the vein material is largely greenish, yellowish, or colorless fluorite which occurs in botryoidal layers with finely granular to columnar structure.

The term "fluorspar" is used to denote the generally impure ore of the mineral fluorite. In the Northgate district, the fluorspar consists largely of fluorite intermixed with finely granular quartz, chalce-' dony, wallrock fragments, and other minor impurities. Concentrations of fluorspar containing 30 percent or more $\mathrm{CaF}_{2}$ are considered to be of ore grade. Locally lower grade-material containing 20 to 25 percent $\mathrm{CaF}_{2}$ is considered to be of commercial interest, even though not of "ore grade" at the time this report was written.

\section{HISTORY}

The veins on Pinkham Mountain were first discovered about 1900 by prospectors looking for copper, but the vein mineral was not identified as fluorite until 1918 when Frank Heaton and Charles Baker staked the Feldspar claim on what is now known as the Fluorspar-Gero-Penber vein zone. Four additional claims were staked in 1921, when the name of the claims was changed to "Fluorspar." These were sold to the Colorado Fluorspar Corp. in 1922 and were patented in 1924. Production on these properties was begun in 1922, and continued until 1926 when a drop in the price of fluorspar forced the mine to close. During this period, the 90- and 200-foot level tunnels were driven at the Fluorspar mine (on the original Feldspar claim, and now the Fluorspar No. 2 claim), and the Gero tunnel on the Fluorspar No. 1 claim was begun. About 15,000 tons of metallurgical fluorspar was produced during this early period of mining activity. Except for minor development and maintenance work, the Fluorspar and Gero mines were not worked from 1927 to 1941.

The southeast end of the east vein of the Fluorspar-Gero-Penber vein zone is in a section of State land (sec. 16, T. 11 N., R. 79 W.) reserved for the support of schools, and thus is not open for mineral claims. The North Park Development Co. obtained a lease on this property, and in 1937 sank a 90 -foot shaft at what is now called the Penber workings. Development and production were stopped after two carloads of metallurgical fluorspar were shipped.

The first location notices on the Fluorine-Camp Creek vein zone were filed in 1924 by Fred Baker and others who staked the Manganese claims Nos. 1, 2, and 3 near where the present Baker pit is situated. A number of prospect pits were dug and a 40-foot shaft 
was sunk, but no production is recorded. The claims were relocated as the Fluorine claims in 1928 by Baker, but the property remained idle except for assessment work until World War II.

Mining activity in the Nortl.gate district was renewed during World War II when Western Fluorspar Corp. leased the Colorado Fluorspar Corp. holdings in 1941 and rehabilitated the Fluorspar mine and mill. The mill burned in December 1942, after about 5 months of production, and a new 450-ton capacity sink-float mill was constructed by Defense Plants Corp. for use of Western Fluorspar Corp. Meanwhile Western Fluorspar Corp. had purchased the Fluorine block of claims and the U.S. Forest Service had constructed a graveled road across Pinkham Mountain providing access to the Fluorine-Camp Creek vein zone. Production was resumed at the mill in November 1943, and continued until August 1945.

Most of the mining in 1942 was done in surface cuts on the east and west veins of the Fluorspar-Gero-Penber vein zone between the later developed Fluorspar glory hole and Springer pit, and about 10,000 tons of mine-run fluorspar was produced. In 1943 the 200 -foot level of the Fluorspar mine was advanced about 200 feet, and the Gero tunnel was advanced about 50 feet. The Baker pit on Fluorine Nos. 1 and 2 claims was opened in 1943 in anticipation of the requirements of the new mill, and about 30,000 tons of mine-run fluorspar was mined by dragline and power shovel and trucked to the mill. During 1944 mining operations continued at the Baker pit, and an additional 34,000 tons of ore was produced. The 90 -foot level of the Fluorspar mine was converted into an opencut in 1944 and ore above this level was largely mined out. About 20,000 tons of fluorspar was produced. Western Fluorspar Corp. obtained a lease on the Penber workings in 1944 and started an opencut along the vein. The Springer pit near the north end of the east vein of the Fluorspar-Gero-Penber vein zone also was started late in 1944. During 1945 the Springer pit produced about 20,000 tons of ore, but some additional fluorspar was mined from the Penber opencut.

The Camp Creek deposit near the northwest end of the FluorineCamp Creek vein zone was discovered in 1943 by Fred Baker and J. H. Miller who located three claims. These were purchased by E. L. McElroy who located two more, the Cunningham and Brimmer. Kramer Mines Inc. leased this property in 1943 and mined about 700 tons of flourspar from an opencut and underground workings before the mine was closed in the fall of 1944. This ore was shipped to the Kramer mill near Salida, Colo., for beneficiation.

The Camp Creek mine was acquired by the Aluminum Company of America in 1950. By 1956 this company had done some mine development work and diamond drilling, but had produced no ore. 
In 1951 the Ozark-Mahoning Co. acquired control of the FluorsparGero-Penber vein zone and the Fluorine claims on the Fluorine-Camp Creek vein zone, and began active mine development work and production. A new flotation mill was constructed and began operating late in 1952.

To 1955 the north headings on the 200 -foot level of the Fluorspar mine had been advanced about 340 feet on the west vein and about 2,200 feet on the east vein, and large stopes had been opened. The Penber shaft had been deepened, and a new level had been established at a depth of about 200 feet. By the end of the summer of 1956, opencuts on the Fluorine-Camp Creek vein zone had been developed over a length of about 4,400 feet, and a large tonnage of ore had been mined by power shovel and had been beneficiated to acid-grade fluorspar.

\section{FLUORSPAR OF LARAMIDE(?) AGE}

Some of the fault breccia along Laramide faults in the Northgate district is highly silicified, and the silicified rock forms masses that range from a few feet in length and 1 or 2 feet in thickness, to nearly 1,000 feet in length and as much as 20 feet in thickness. The silicified breccia is made up in large part of red cherty silica cut by stringers of white comb-quartz. The fragmental character of the silicified rock is obvious, and in places several periods of brecciation and silicification are apparent. Small pods of finely granular gray vein quartz containing a small amount of country rock occur within the silicified masses and as separate bodies along the faults, and locally these contain coarsely crystalline fluorite. Few of the quartzfluorite bodies are well exposed, but scattered outcrops and float suggest that such bodies range from a few feet to about 100 feet in length, and from a few inches to nearly 10 feet in thickness. Fine-grained gray quartz is the most abundant vein material; fluorite generally is sparse and is very irregularly distributed.

The quartz-fluorite bodies also show the effects of repeated brecciation and vein deposition, and the close association with the larger masses of silicified fault breccia suggests that they were formed under the same conditions. Stringers of white comb quartz heal most of the fractures in the siliceous fault breccia and the enclosed quartzfluorite veins, and the silicified fault breccia generally is "frozen" to the less broken walls where the silicification fades out gradually through a zone a few inches to a few feet thick. The repeated brecciation evidently took place while the faults were still active, and silicification persisted after movement ceased. In those few places where silicified masses were broken again by late-Tertiary (?) faulting, and fluorspar again was deposited, the younger fissures are 
marked by open breccia only partly healed by crustified fluorspar of markedly different aspect.

Most of the vein material is made up of very fine grained gray quartz that looks homogeneous in rough hand specimen, but on wet or polished surfaces can be seen to consist of angular fragments set in a matrix of similar material. Locally the vein material contains abundant silicified wallrock fragments and is distinctly reddish or yellowish. The larger fragments are fairly easy to recognize, but many of the smaller fragments are nearly indistinguishable from the gray quartz of the matrix. Where not broken by the recurrent fracturing, the local concentrations of fluorite consist of coarsegrained purple, green, white, or colorless crystals as much as 1 or 2 inches in diameter. Although generally irregular, the crystals tend to be equidimensional, and the octahedral cleavage is easily discerned. A few of the fluorite crystals show distinct color banding which may represent growth rings, but more commonly the colors vary haphazardly within the crystals.

The closely associated quartz and fluorite show no consistent sequence of deposition in the veins. Angular fragments of fluorite are locally common in the granular gray quartz, although in other places fluorite veinlets cut the gray quartz and some coarse fluorite occurs in the white comb-quartz stringers which were the last material to be deposited in the silicified breccia. An almost negligible quantity of calcite occurs in one small quartz-fluorite body on Pinkham Peak, and apparently formed contemporaneously with the associated fluorite.

Most of the bodies of silicified breccia containing the quartz-fluorite pods occur along the Independence Mountain fault zone. They are most common in the imbricate segments of the zone, and most of the known bodies are along the higher fractures where brittle Precambrian rocks form both walls of the fractures. Laramide(?) fluorspar also was seen along a subordinate fissure in the hanging wall of the Government Creek fault near the southeast corner of the Northgate district.

\section{FLUORSPAR OF LATE TERTIARY(?) AGE}

The largest deposits of fluorspar in the Northgate district occur along the late Tertiary (?) faults on Pinkham Mountain. The Fluorspar-Gero-Penber and Fluorine-Camp Creek vein zones supplied all of the fluorspar mined in the district to 1956, and they contain the largest known reserves of ore.

Both vein zones on Pinkham Mountain occur along faults which cut Precambrian rocks for most of their length, but offset some Oligocene White River rocks as well. Most ore shoots occur where these faults cut hard, competent granitic rocks, and the fractures stood open during vein deposition. Little or no vein material was de- 
posited in the tight fractures where less competent hornblende- and biotite-rich metamorphic rocks were offset. Intrusive quartz monzonite is the most favorable host rock, but mine workings developed along the Fluorine-Camp Creek vein zone have exposed good ore between walls of quartz monzonite gneiss as well. Almost all of the ore mined to 1956 came from fractures in the granitic rocks, or from mineralized White River formation overlying faulted granitic rocks.

The late Tertiary fluorspar varies widely in appearance from place to place, but all occurrences have enough features in common to distinguish this type readily from the older fluorspar of probable Laramide age. The fluorite typically occurs in columnar to granular layers and aggregates, and associated fine-grained quartz and chalcedony are generally subordinate. Open spaces are common and range in size from small drusy cavities to large irregular "water courses." The largest of these water courses is exposed on the lower level of the Penber mine where a cavity appeared at least 20 feet wide, 200 feet long, and nearly 100 feet high in largest dimensions.

The wallrocks along both the Fluorspar-Gero-Penber and FluorineCamp Creek vein zones, and the wallrock fragments within the vein zones, are irregularly silicified. The country rock is rarely silicified for more than a few inches to a few feet beyond the walls of the veins, however, and generally is not conspicuous enough to serve as il guide to ore in areas of poor exposures.

\section{VEIN MATERIAL ON THE FIUORSPAR-GERO-PENBER VEIN ZONE}

The fluorspar along the Fluorspar-Gero-Penber vein zone occurs in a complex network of branching veins that cut through coarse fault breccia. Individual strands within the braided network of filled fissures that constitute the vein zone range from mere seams to strong veins 10 or more feet in thickness. The fractures along this vein zone were more open during vein deposition than those along the other vein zones in the district, and the fluorspar consists typically of botryoidal layers that formed as successive encrustrations along the open fractures. Although the layering is generally parallel to the walls, nodular masses with crudely concentric layers of fluorspar surrounding fragments of country rock are common, particularly near cavities or "water courses."

The fluorite ranges from columnar to granular, and many veins contain layers of all varieties. The columnar and coarser granular varieties commonly are clear to translucent, and the colors range from delicate tints of green, lavender, and yellow, to white or colorless. Finer aggregates of granular fluorite show a similar range of colors where they are nearly pure, but commonly they enclose variable

$542861-60-6$ 
quantities of clayey material and are yellowish or brownish and have an earthy appearance. Layering is locally subordinate along some individual veins, and the fluorite here occurs in massive granular aggregates. Fine-grained quartz or chalcedony is locally abundant and generally is complexly mixed with fluorite to form a compact, white, porcelaneous-appearing aggregate; this siliceous material forms individual crusts or irregular masses within the otherwise nearly pure fluorite.

Columnar fluorite along the Fluorspar-Gero-Penber vein zone ranges from fine-grained, fibrous-appearing aggregates to coarsely crystalline layers made up of grains as much as one-quarter inch in thickness and more than 1 inch in length. Drusy cavities are lined with crystal terminations, and where these can be recognized they commonly show three cubic faces, with the enclosed axis of threefold symmetry about parallel to the elongation of the columnar grain. This habit is not found in all cavities, but it is sufficiently common to indicate that this is a preferred direction of growth. More commonly the terminations are so rounded, or are so combined with adjacent terminations that the individual faces cannot be recognized. Most color banding is between different layers of columnar crystals, but some coarse-grained layers show banding within individual crystals. Thin films of clay separate some of the layers in this type of fluorspar, but generally the veins consist largely of columnar fluorite.

The lower parts of many of the larger water courses are partly filled with fragments of fluorspar and wallrocks, which range from clay and fine-sand size to pebbles 3 or 4 inches in diameter, and are angular to rounded. Angular fragments of the country rock are commonly coated with concentric layers of fluorspar and in places are cemented together into porous rubbly aggregates. Angular fragments of layered fluorspar are abundant locally and form irregular disoriented aggregates; some of these aggregates are cemented by younger layers of fluorspar but others are loose or have the interstices between the jack-strawed fragments filled with clay and fine frag. ments of vein and wallrock materials. The rounded pebbles are mostly of granitic rocks from the walls of the veins. Many of these pebbles have been worn smooth and are nearly polished. The larger pebbles are generally the most thoroughly rounded; the smaller fragments, an inch or less in diameter, tend to be irregular and many have had only the edges and corners worn smooth. In most places the rounded pebbles are set in a sticky gray or greenish matrix consisting of unsorted clay- and sand-sized particles of wallrocks and fluorite. At one place in the Springer pit, seams of crustified fluorite cut the clay-fragment rubble in the bottom of a water course. 


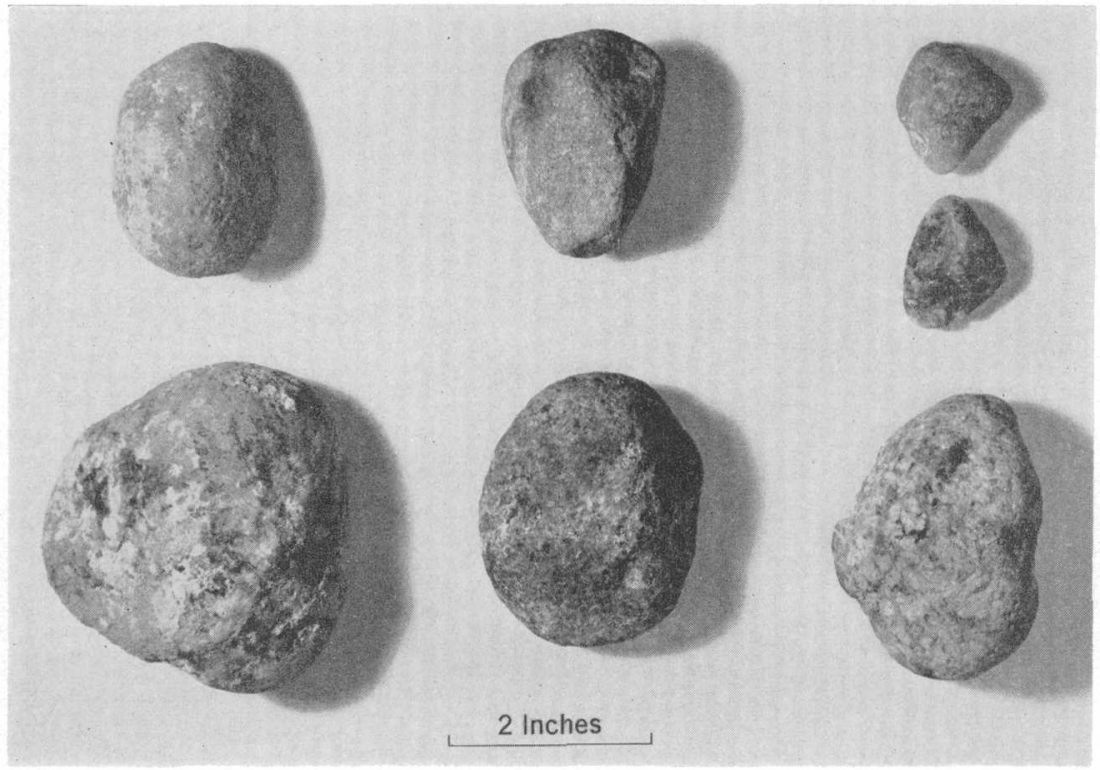

ROUNDED PEBBLES FROM THE FLUORSPAR.GERO-PENBER VEIN ZONE 

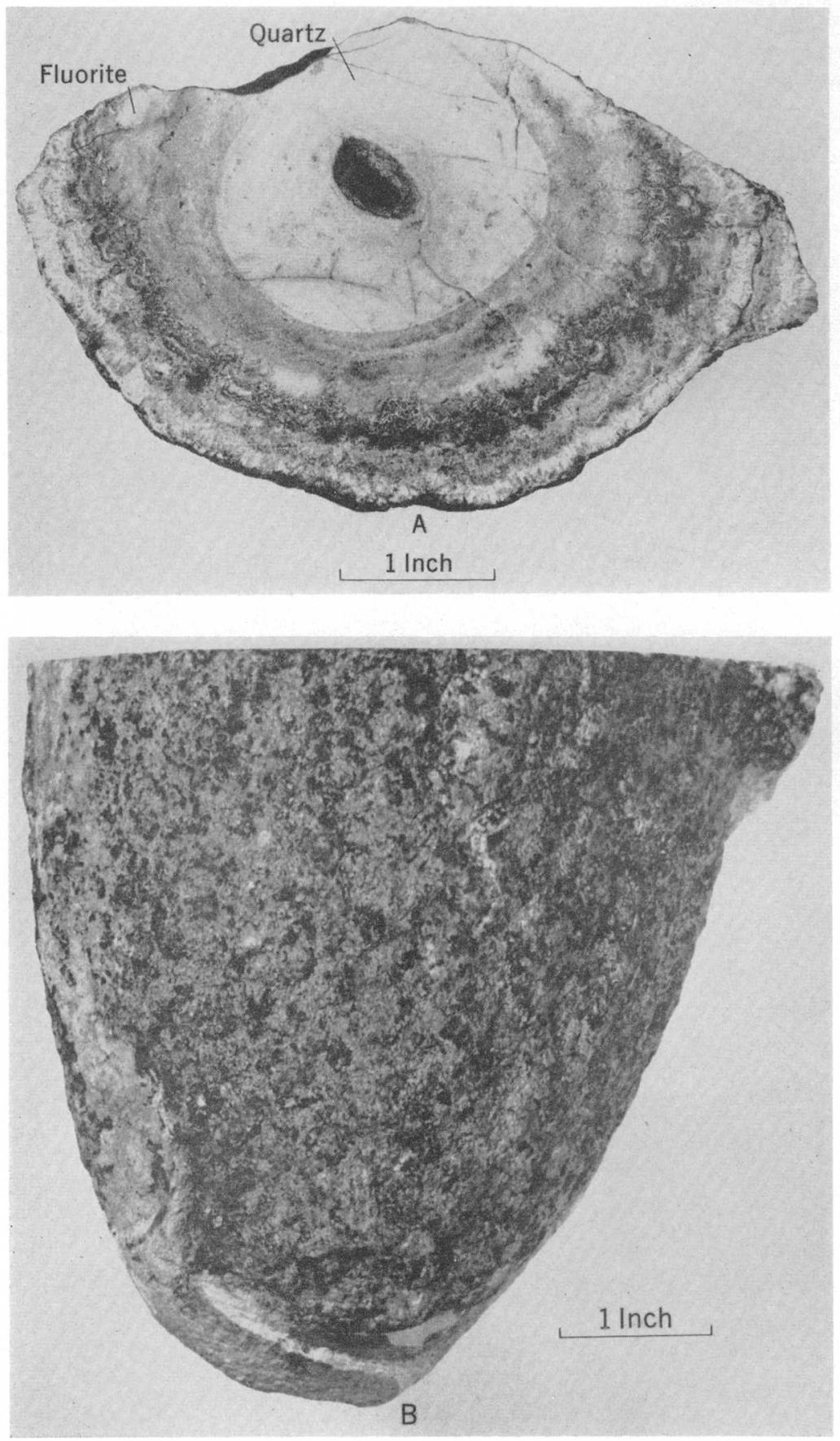

STALACTITIC GROWTH FROM THE SPRINGER PIT, FLUORSPAR.GERO.PENBER VEIN ZONE

$A$. Top view $B$. Front view. 
The rounded or subrounded fragments of wallrocks have the appearance of typical stream deposits (pl. 16), and probably formed by attrition from rock fragments broken from the walls of the cavities and agitated together by water moving either up or along the fault zone. At one place the rounded pebbles and finer particles appeared to be "bedded," as though deposited from a laterally directed current of water, or by differential settling through irregularly agitated water.

A stalactitic growth of layered quartz and fluorite (pl. 17) was collected from the overhanging wall of a steeply dipping water course exposed in the Springer pit. The maximum width of the water course was 1 to 2 feet, and was separated from the granitic country rock in the wall of the vein by several feet of typical crustified fluorspar. The core of the stalactitic growth is finely granular white quartz, which contains a central tubular opening typical of stalactites. The core is covered in turn by crustified fluorite which does not show the central opening, and may represent an overgrowth of vein fluorite over an earlier stalactite. These relations indicate fluctuating conditions of vein growth, some of which appear to have involved deposition above water table.

The significance of these different features of the vein zone will be considered in more detail in the section on "Environment of deposition."

Fluorspar within the individual strands of the braided vein zone is generally high grade, and commonly contains as much as 90 percent $\mathrm{CaF}_{2}$. Where fine-grained quartz is abundant, however, the vein material may contain as little as 40 or 50 percent $\mathrm{CaF}_{2}$. Country rock comprises the chief impurity in the mine-run ore, and the relative proportions of fissure filling and wallrock within the width of the vein zone that is mined generally controls the grade of the ore produced. The country rock occurs both as fluorspar-coated fragments within the vein material, or as broken septa between the braided strands of the vein zone. As much as 2 percent of fine-grained pyrite is locally disseminated through the fluorspar and adjacent wallrock, or forms thin crusts lining small cavities, although generally it is very sparse.

Assays given by Warne $(1947$, p. 19-20) for the vein zone in the vicinity of the Gero and Penber workings indicate the general grade of the Fluorspar-Gero-Penber vein zone. Samples taken from highgrade stringers commonly contain more than 80 percent $\mathrm{CaF}_{2}$ and 1 assay showed nearly 97 percent $\mathrm{CaF}_{2}$. Local widths of 3 to 6 feet across the vein zone average nearly 60 percent $\mathrm{CaF}_{2}$. Some series of samples that range from 16 or 17 percent to more than 90 percent $\mathrm{CaF}_{2}$ average between 40 and 50 percent $\mathrm{CaF}_{2}$ for widths of 8 to 11 feet. 


\section{VEIN MATERIAL ON THE FLUORINE-CAMP CREEK VEIN ZONE}

Much of the fluorspar along the Fluorine-Camp Creek vein zone lacks the clean appearance of the vein material along the FluorsparGero-Penber vein zone and is not as pure. It occurs largely as lacing veinlets cementing fine-grained fault breccia, and as earthy aggregates replacing and impregnating the gougy matrix of the breccia and the associated White River rocks. The irregular veinlets commonly consist of clear to translucent columnar fluorspar that ranges from greenish to yellowish and amber. Granular fluorspar fills some of the veinlets, but is more common in the impregnated or replaced parts of the vein zone. Some granular fluorspar is made up of translucent aggregates of greenish to lavender fluorite grains, but this is greatly subordinate to the more impure reddish to brownish earthy varieties. In places small colorless or faintly tinted fluorite crystals form porous, skeletal aggregates lining or partly filling drusy cavities. Some of these cavity linings are delicately layered and have irregular to crudely rounded protuberences which show a complex aggregate of crystal faces. Other cavities are partly filled with honeycomb boxwork of small fluorite crystals that have grown to form intersecting walls.

The fluorspar in the White River rocks in part fills fractures, and in part impregnates and cements the arkosic and ashy beds.

The fluorspar of the Fluorine-Camp Creek zone contains many minor impurities which stain the ore. Soft, powdery manganese oxide coats many fractures and partly fills some drusy cavities where it commonly is associated with a white clay that was determined by $\mathrm{X}$-ray methods as a mixture of montmorillonite and fluorite. Manganese oxide is intergrown with the small, idiomorphic fluorite crystals that line the cavities, but the white clay generally is found only in the cavities. Sparse veinlets of chalcedony fill fractures in the fluorspar and line some of the cavities; it appears more abundant in mineralized White River formation than in the broken and mineralized granitic rocks, but quantitative data on this are lacking.

Assays quoted by Warne (1947, p. 15-20) indicate the general grade of the vein material on the Fluorine-Camp Creek vein zone. The highest assays given for thicknesses of more than 1 or 2 feet were from the Camp Creek mine where the ore contained between 70 and 80 percent $\mathrm{CaF}_{2}$ for a width of about 5 feet. At the same place, the vein zone contained more than 30 percent $\mathrm{CaF}_{2}$ for a width of about 16 feet. Assays from the Bureau of Mines shaft (Fluorine No. 1 shaft) showed that the mineralized White River rocks exposed on the 53-foot level contain about 32 percent $\mathrm{CaF}_{2}$ for a 15 -foot width, and between 20 and 25 percent $\mathrm{CaF}_{2}$ for a 35 -foot width. On deeper levels where intrusive quartz monzonite constitutes the walls, 
the vein zone generally contains between 30 and 60 percent $\mathrm{CaF}_{2}$ and averages between 40 and 50 percent $\mathrm{CaF}_{2}$ for widths of 25 : to 30 feet. Composite samples for widths of 35 to 45 feet contained about 30 percent $\mathrm{CaF}_{2}$. Other assays from scattered trenches along the Fluorine-Camp Creek vein zone show a similar range in grade.

\section{STRUCTURAL CONTROI}

Fluorspar was deposited in or adjacent to open spaces along late Tertiary (?) faults, and the larger bodies of ore are localized where the fractures were most abundant or open. A major controlling factor was the competency of the wallrock; hard rocks in which open fractures could be maintained were favorable hosts, whereas soft rocks in which the fractures were tight are commonly virtually barren of fluorspar. Intrusive quartz monzonite was a favored host, and most of the higher-grade deposits have this rock on one or more of the walls. Quartz monzonite gneiss also was relatively favorable, particularly where the mineralized fractures cut the foliation at high angles, and a large quantity of fluorspar has been produced from between walls of this rock along the Fluorine-Camp Creek vein zone. Hornblende gneiss and hornblende-biotite gneiss, on the other hand, were less competent, and the fractures tended to be tight and unfavorable for deposition of significant fluorspar. The White River rocks, although soft and incompetent, were favorable host rocks, especially where they overlie the hard granitic rocks; the White River tended to become impregnated rather than veined by fluorspar, however, and fracture control was less important.

Although the faults followed by the main vein zones had predominant right-lateral strike-slip movement, the character of the fractures produced and the shape and structural control of the ore shoots formed contrast markedly from one vein zone to the other. The minor displacement along the Fluorspar-Gero-Penber fault zone produced irregular but fairly persistent fractures with little gouge or fine breccia along the east and west margins of the zone. The rock within the fault zone is locally broken by fractures that range from longitudinal fissures nearly parallel to the wall, to diagona] tensional fissures that trend northeast across the fault zone. Lateral displacement along the irregular bounding fractures and the diagonal tensional fractures resulted in many open spaces that later were filled or partly filled by crustified fluorspar.

Many larger pods of high-grade fluorspar along the FluorsparGero-Penber fault zone are localized in or near those bends in the marginal fractures that deflect the trend of the fractures to the right. Clear-cut examples of this type of control are shown at the surface in the vicinity of the Springer pit and the glory hole (pl. 14) and 
along the northern two-thirds of the east vein exposed on the 200-foot level of the Fluorspar mine (pl. 13). These pods obviously filled open spaces produced by right-lateral displacement along the irregular fractures.

The diagonal tension fractures that cut across the Fluorspar-GeroPenber fault zone are locally abundant, and in places the fractured rock contains fluorspar ore. These fractures are rarely apparent at the surface, but they are clearly shown at several places on the 200-foot level of the Fluorspar mine (pl. 13). The diagonal fractures between coordinates $3,800 \mathrm{~N}$. and $4,000 \mathrm{~N}$. served to shift the major displacement along the fault zone from the west wall to the east wall, and they are more closely spaced and contain more fluorspar than any other local concentration of diagonal fractures seen on the Fluorspar-Gero-Penber vein zone.

Many straight segments of the marginal fractures on the FluorsparGero-Penber vein zone contain abundant fluorspar, but show no relation to local irregularities or deflections in trend. In many places, such as along the west vein on the 200-foot level of the Fluorspar mine (pl. 13), the vein had been largely stoped before the time of fieldwork so the detailed structures could not be observed. The straight segments exposed in the Gero and Penber workings (figs. 40 and 41), however, consist of irregularly lacing veinlets of fluorspar with local high-grade pods and incompletely filled "water courses." Here the fractures split and join in a very complex manner. Where a single fracture predominates, it commonly remained open and either was filled with crustified fluorspar to form a high-grade pod of ore, or was incompletely filled and remains in part as an open "water course." The walls of these larger open spaces probably were forced apart by the wedging action in adjacent segments of the vein where movement was taken up along many lacing fractures. The fluorspar vein strands in the highly broken segments comprise a much smaller percentage of the vein zone than in the nearby high-grade pods, and the tenor of ore varies sharply from place to place.

The greater displacement along the Fluorine-Camp Creek fault produced a persistent zone of breccia ranging from 10 to nearly 70 feet in width that extends for most of the known length of the fault zone across the top of Pinkham Mountain (pl. 15). By fall, 1956, Ozark-Mahoning Co. had developed continuous opencuts for nearly 4,400 feet (virtually all the southeastern half of the vein zone shown on pl. 15), and within this distance the zone averaged nearly 20 feet in width and only rarely was less than 15 feet.

The widest parts of the Fluorine-Camp Creek vein zone seem to be along the more northward-trending segments of the sinuous fault zone, as they theoretically should along a northwestward-trending 


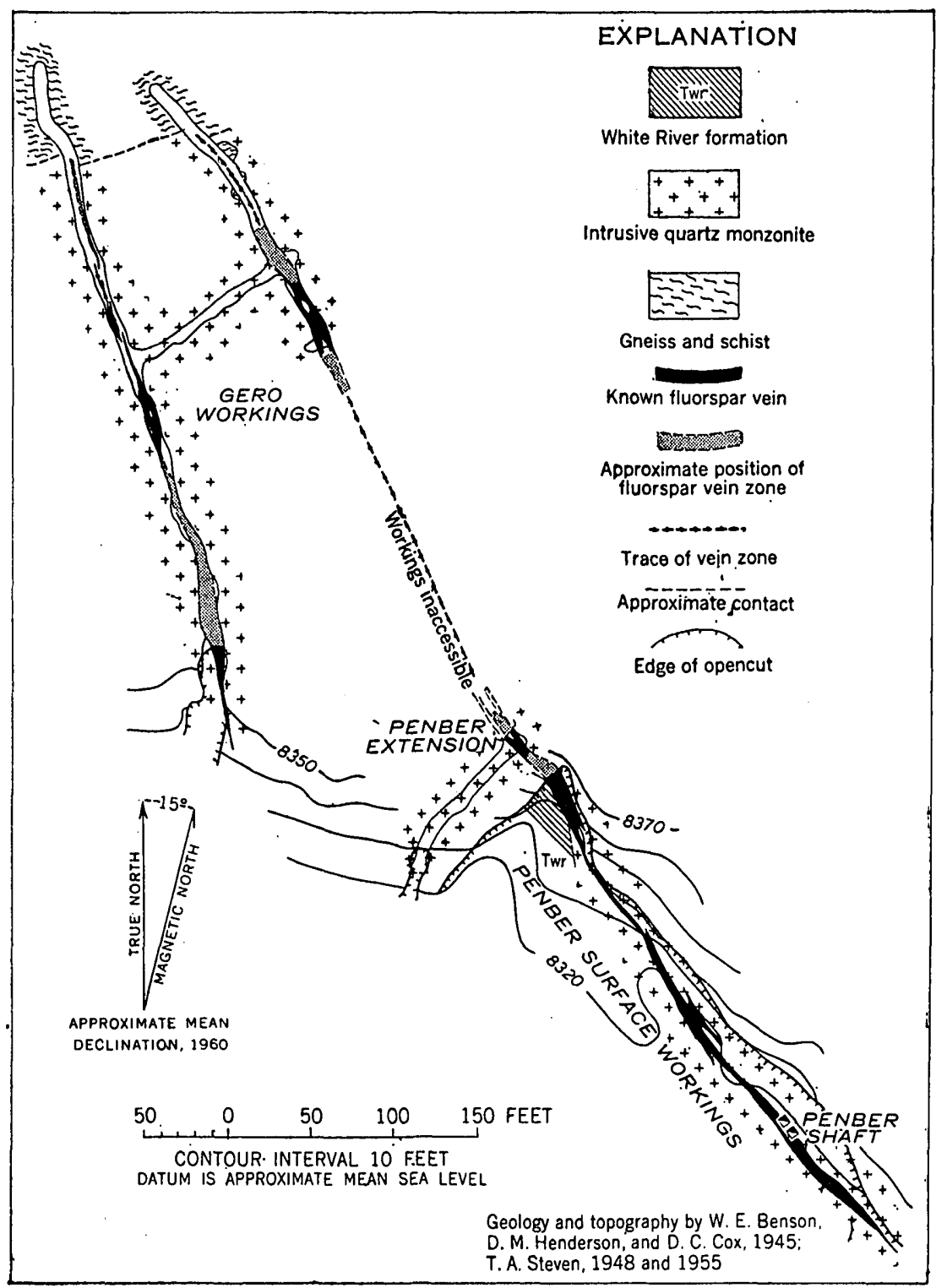

Figdri 40.-Geologic map of the Gero workings and Penber surface workings.

fault with right-lateral displacement. Within the area of the opencuts the vein zone is thinnest northwest of the old Baker pit, where the fault zone is deflected to the left (pl. 15). This deflection also nearly coincides with a change in wallrock from hard intrusive quartz monzonite to less competent hornblende and hornblende-biotite gneiss and schist, and the thinning here may be due both to lithologic and structural factors. The Fluorine-Camp Creek vein zone thins mark- 


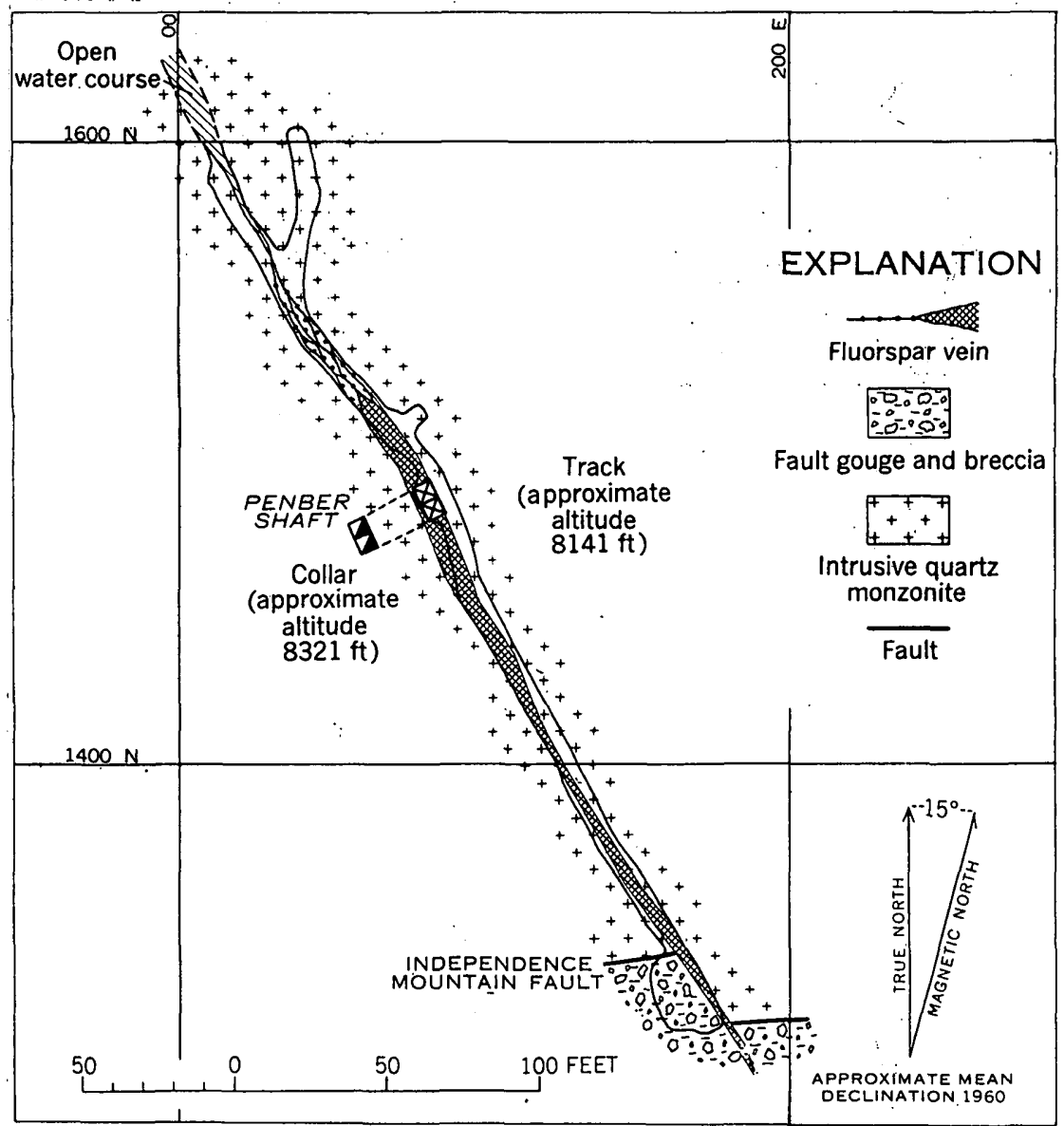

Base modified from an

Ozark.Mahoning map, 1956.

Coordinates by Ozark.Mahoning Co.

Figorn 41.-Geologic map of the lower level, Penber mine.

edly along a more westerward-trending segment near the southeast end of the Fluorine mine (pl. 15) where the vein zone is deflected sharply to the left. This deflected segment is characterized by a lower dip (near $60^{\circ}$ ) and by abundant handling-wall fractures filled with fluorspar; these features will be discussed in later paragraphs in this section.

Exposures were very poor along the northern half of the FluorineCamp Creek vein zone, and little could be determined about the details of ore localization. Those ore bodies known at the time of fieldwork were in or adjacent to faulted ends of intrusive quartz monzonite dikes, and no close correlation with bends in the containing fault seemed indicated. Only the western of the two main branches of the fault zone had been explored and this one only locally. The 
eastern branch apparently had the greater displacement and locally at least the rocks nearby contained abundant fluorspar in minor fractures." The rocks near the junction of the two fault branches are largely granitic in composition, probably are highly fractured, and thus may contain abundant fluorspar. The deflection to the left of the western fault branch near the junction may not be as unfavorable as similar deflections farther southeast, for the displacement on this branch seems to have been largely left-lateral, rather than rightlateral as along the main part of the fault zone.

Preliminary diamond drilling by Ozark-Mahoning Co. during the summer of 1956 disclosed that the hanging wall of the main FluorineCamp Creek vein zone near the old Baker pit and the Bureau of Mines shaft (pl. 15) is highly fractured and veined by fluorspar. In places the whole hanging-wall block for as much as 200 feet from the main vein zone contains enough fluorspar to be of definite economic interest, even though below current ore grades; elsewhere the concentrations of ore are more local, although good shows of fluorspar were found sporadically in the hanging-wall block in all the holes drilled. Ozark-Mahoning Co. was actively exploring this sector of the hangingwall block when this report was prepared; the work was still in a preliminary stage, however, and insufficient data were available to permit evaluation of the discovery. Possibly these hanging-wall veins reflect a northwestward continuation of fracturing along trend from the marked deflection in strike near the southeast end of the Fluorine mine (pl. 15). A diamond-drill hole that intersected the deflected segment of the fault between 100 and 200 feet below the surface showed that the dip of the fault zone here was near $60^{\circ} \mathrm{NE}$, which is much flatter than is normal along the fault zone. Rightlateral strike-slip movement would have applied great stress to the hanging-wall block northwest of this flattened and deflected segment, and exposures in surface outcrops and in the walls of the opencuts show that longitudinal fissures and diagonal tension fissures are particularly abundant in this vicinity.

At the time of writing (1956), it was not known whether the fractures followed by the hanging-wall veins are longitudinal or diagonal. It seems likely that the fluorspar in the hanging wall would show a greater lateral persistence if most of the fractures are about parallel to the main vein zone than if diagonal fissures are dominant.

\section{VERTICAL RANGE OF FLUORSPAR DEPOSITS}

Owing to the limited number of fluorspar-bearing vein zones in the Northgate district, the vertical range of fluorspar deposition is a critical limiting factor in the economic geology of the district. The known vertical range of commercial-grade fluorspar in the district at the time this report was prepared (1956) was about 1,050 feet, 
measured from near the old Baker pit on the Fluorine-Camp Creek vein zone (altitude approximately 9,170 feet) to the bottom of the Penber shaft on the Fluorspar-Gero-Penber vein zone (altitude approximately 8,120 feet). The known vertical ranges on the individual vein zones, however, were only about 600 feet for the FluorsparGero-Penber vein zone and about 370 feet for the Fluorine-Camp Creek vein zone.

Fluorspar has the same general aspect throughout the exposed range of 600 feet on the Fluorspar-Gero-Penber vein zone (pl. 14), from the surfaces at the Springer pit to the 200-foot tunnel level in the vicinity of the Fluorspar mine, and from the Gero workings to the bottom of the Penber shaft near the south end of the vein zone. Although the grade varies greatly from place to place, the changes are not systematic, and the ore on the lower levels of the Penber mine seem fully as high grade as that in the better pods exposed in upper levels along the vein zone. Although many features of these deposits suggest near-surface deposition (p. 407), no evidence was seen in the accessible workings to indicate that the bottom of the ore zone was near.

Mine workings along the Fluorine-Camp Creek vein zone (pl. 15) expose a much more limited vertical range of fluorspar, and surface exposures are very poor southeast of the Fluorine mine where the valley of Lawrence Creek cuts deeply across the trend of the vein zone. Opencuts have developed ore along the vein zone down to an altitude of about 8,880 feet, approximately 290 feet below the high point on the vein zone in the vicinity of an old Baker pit. A series of diamond-drill holes drilled by Ozark-Mahoning Co. beneath a segment of the vein zone extending 600 feet northwest and 800 feet southeast of the Bureau of Mines shaft cut minable fluorspar along the vein zone at several places near an altitude of 8,800 feet, approximately 370 feet beneath the surface at the old Baker pit. Although sufficient data are not available to predict the lateral continuity of the fluorspar, ore of comparable grade and thickness extends, in places at least, from near the surface to the deepest levels tested. This is well shown beneath the Bureau of Mines shaft, where samples analyzed by the U.S. Bureau of Mines (Warne, 1947, p. 16-18) show that 25- to 35-foot widths of the vein zone average between 30 and 40 percent $\mathrm{CaF}_{2}$ to a depth of 150 feet. A diamond-drill hole drilled by Ozark-Mahoning Co. intersected the vein zone between 200 and 225 feet beneath the bottom of the shaft, and samples analyzed by them show that fluorspar of comparable grade and thickness is present at that depth. The results of the other drill holes were not uniformly encouraging, however, and without additional testing or development work it must be considered possible that the Fluorine-Camp Creek vein zone locally may become less mineralized and perhaps somewhat narrower at relatively shallow 
depths. On the other hand, an outcrop of brecciated intrusive quartz monzonite along the southeastern part of the vein zone near the bottom of Lawrence Creek valley exposes a good showing of fluorspar at an altitude of about 8,580 feet. This test pit is nearly 600 feet below the surface near the old Baker pit, and it seems likely that fluorspar along the Fluorine-Camp Creek vein zone locally may have a vertical range comparable with that known on the Fluorspar-GeroPenber vein zone.

\section{ENVIRONMENT OF DEPOSTTION}

Many features of the fluorspar in the Northgate district indicate deposition in a very shallow environment. The veins consist of crustified breccia-fillings with numerous open spaces ranging from small pores to large cavities as much as 20 feet in width and several hundred feet in diameter in the plane of the vein. The water courses commonly contain rounded pebble- and sand-sized particles of the wallrocks that were worn smooth, probably by attrition in moving ground water. Silica occurs as chalcedony or finely granular quartz, phases that generally form under shallow conditions. A stalactitic growth of quartz-fluorite that was an integral part of the vein filling was collected from the wall of one of the open cavities. These features, in conjunction with what information could be obtained on the solubility of $\mathrm{CaF}_{2}$, on the general lack of wallrock alteration, on the temperature of deposition, and on the geomorphic history of the area, are the bases for interpreting the environment of deposition of the fluorspar in the Northgate district.

\section{DEPTH OF DEPOSITION}

The geomorphic history of the Northgate district was studied in detail (Steven, 1956) to determine the depth of fluorspar deposition. However, both the late Tertiary (?) faulting and fluorspar deposition took place after the North Park formation was deposited and before the Medicine Bow surface was cut, and it has not been possible to establish when within this interval the faulting and mineralization took place nor the position of the land surface at any given time.

The Medicine Bow surface bevels the Fluorine-Camp Creek vein zone, and projects over at least part of the Fluorspar-Gero-Penber vein zone at present altitudes of 8,900 to 9,000 feet, 200 to 300 feet above the highest outcrop of that vein zone at the Springer pit (Steven, 1956, fig. 2). Insofar as available direct evidence permits, the depth of cover above this surface at the time of mineralization could have been as little as a few feet, or as much as a thousand feet or more. An estimate must depend largely on interpretations of conditions of fluorspar deposition developed in subsequent sections, and thus cannot be used to support these interpretations. 


\section{COMPOSITION OF THE MTNERALIZING FIUID}

Although close estimates of the depth of fluorspar deposition cannot be made, the general geomorphic history of the Northgate district (Steven, 1956) (also see "Geomorphology," p. 382) indicates that deposition was well within the depth to which meteoric water is known to penetrate. The land surface since the development of the preWhite River erosion surface in Oligocene time has fluctuated from approximate present levels to levels controlled by the depths of fill attained by the White River and North Park formations, which probably were no more than a few thousand feet at the most. The abundant evidence for open fractures and loose breccia along the mineralized faults makes it probable that meteoric water circulated freely at the time of mineralization, and thus was a major component of the mineralizing fluid.

Calcium and fluorine were obviously present in the mineralizing fluid. In addition some silica probably was present to account for the silicified wallrocks and the quartz and chalcedony deposited locally in the veins; and manganese and aluminum are required by the manganese oxide and hydrothermal montmorillonite found locally along the Fluorine-Camp Creek vein zone. Sulfide minerals are rare in the vein zones, and no evidence was seen for acid-sulfate alteration of the wallrocks, therefore, the concentration of $\mathrm{H}_{2} \mathrm{~S}$ probably was very low. Carbonate minerals are negligible in the vein zones, which in conjunction with the evidence for available calcium, makes it unlikely that $\mathrm{CO}_{2}$ was a significant constituent.

Estimates of the concentration of calcium and fluorine in the aqueous mineralizing solution are based on the lack of significant wallrock alteration, and on the sparse solubility data which indicate that $\mathrm{CaF}_{2}$ is only slightly soluble in water. Except for minor silicification, the wallrocks on the vein zones are virtually unaltered. In addition, the relative favorability of the different host rocks is dependent-largely on physical characteristics rather than on chemical composition. Thus it seems required that both the calcium and fluorine for the fluorite be transported in solution. Data on the solubility of $\mathrm{CaF}_{2}$ in water as given by Seidell $(1940$, p. 296) are tabulated as follows:

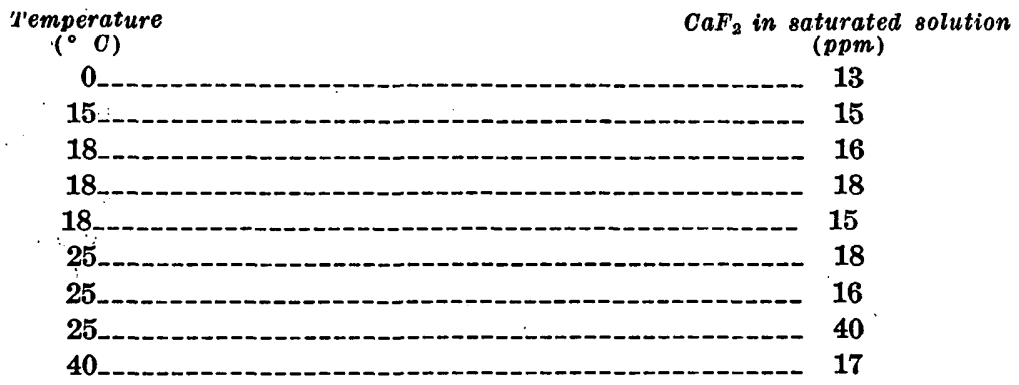


The fluorspar at Northgate probably was deposited at temperatures between $100^{\circ}$ and $150^{\circ} \mathrm{C}$ (see "Temperature of deposition"), and the solubility of fluorite at these higher temperatures may be significantly different than that within the range determined, although no particular increase in solubility with an increase in temperature is apparent in the data given above. However, even were the solubility to increase by a factor of 10 at $150^{\circ}$, the resulting solution would still be very dilute and the general conclusion that the concentrations of calcium and fluorine in the mineralizing solution were low seems valid.

More important factors modifying the solubility of $\mathrm{CaF}_{2}$ in the mineralizing solution may have been the presence of other ions, differences in $\mathrm{pH}$ and differences in pressure. As indicated above, some silica, aluminum, and manganese were certainly present, and other unknown constituents may have been present. The possible effects of these factors cannot be assessed directly, but the assumption for low concentrations of calcium and fluorine in the mineralizing solution at Northgate is supported by the generally low concentrations of these elements in modern hot springs associated with known fluorite-bearing deposits. As quoted by White (1955, p. 143), the hot springs at Ojo Caliente, New Mex., contain $16 \mathrm{ppm}$ fluorine and $25 \mathrm{ppm}$ calcium; the hot springs at Poncha Springs, Colo., contain $12 \mathrm{ppm}$ fluoride and $17 \mathrm{ppm}$ calcium; and the warm springs in the Browns Canyon district, Colorado contain $15 \mathrm{ppm}$ fluoride. Although the main period of fluorspar deposition seems to have ended at each of these thermal areas, some fluorite is reported from modern travertine at Poncha Springs (White, 1955 , p. 143, quoting R. T. Russell, unpublished $\mathrm{Ph}$. D. thesis, Univ. of Cincinnati) so the concentrations here at least appear to approach saturation. The present natural waters at each of these areas undoubtedly contain ions other than calcium and fluorine, but no evidence is apparent that the solubility of these materials increased.

From personal observations and as described by Cox $(1945$, p. 270274), the vein material in the Browns Canyon and Poncha Springs districts is crustified, columnar to granular fluorspar. closely similar to that at Northgate. Silica, as chalcedony or finely granular quartz, is the chief vein material besides fluorite, although a little pyrite is present locally. Open "water courses" are common along the veins. These deposits are so closely similar to those at Northgate that a common environment of deposition seems required.

\section{TEMPERATURE OF DEPOSITION}

A series of chips of fluorite from several mines in the Northgate district were scanned for fluid inclusions, with the intent to measure the approximate temperature of deposition by determining the tem- 
perature at which the vapor phase in the 2-phase inclusions disappears. The results were generally disappointing, as the inclusions were very sparse, small, and irregularly distributed. Although several chips each from 12 specimens were scanned carefully, measurable inclusions were found in only 3 specimens, and within these 3 specimens the inclusions were limited to only 1 or 2 of the crustified layers.

Those inclusions that were seen were all very small negative crystals, many of which contain vapor and liquid phases with an apparent constant ratio between phases. Only a few were large enough for the vapor and liquid phases to be discerned clearly under $80 \times$ magnification; most required $240 \times$ magnification to be clearly seen and measured. In addition, many of the inclusions that were found were so oriented that the vapor-phase bubbles were obscured by total reflection from steeply inclined faces or sharp edges or corners of the negative crystals. Many times a bubble that was clearly observed during one or more heating measurements would move into a shadow where it no longer could be seen.

The sparse results from heating the fluid inclusions and observing the tempertures at which the vapor phase disappears are tabulated below:

TABLE 2.-Data from fluid inclusions in fluorite from the Northgate district

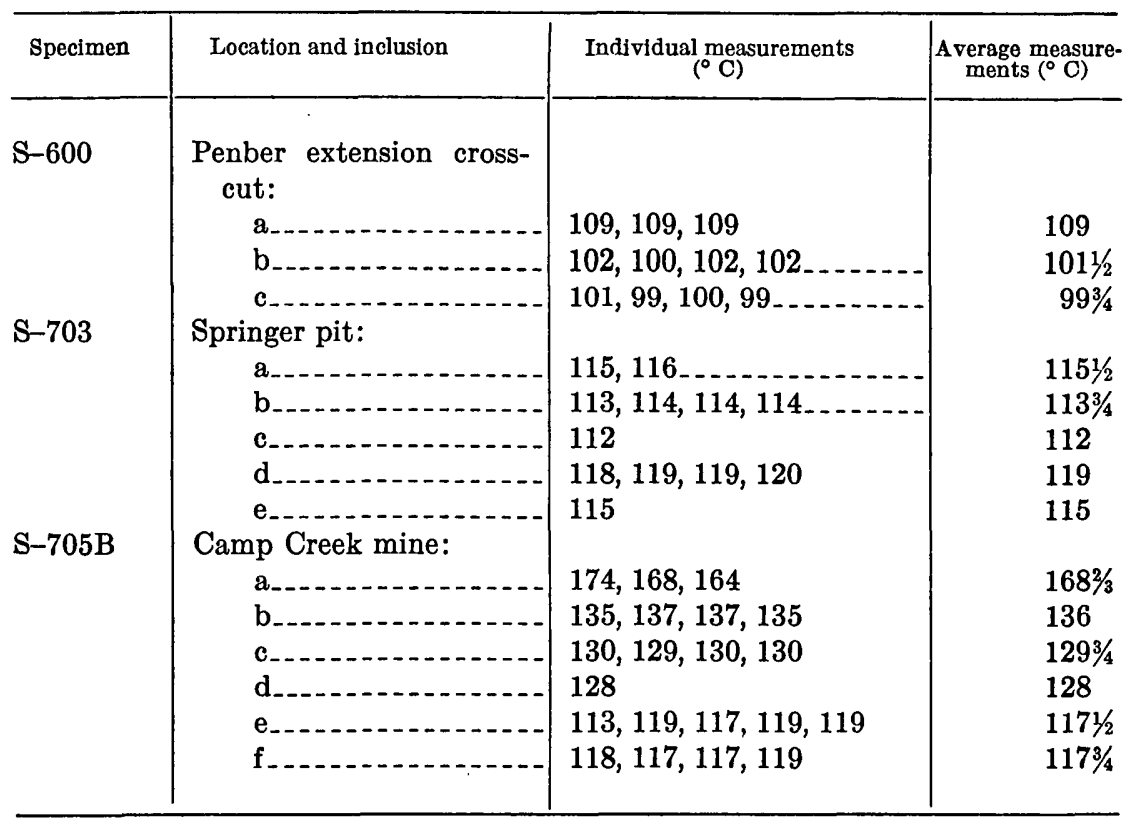

These results should approximate the temperatures of deposition of the fluorite, providing that the inclusions are primary growth features that were completely filled with the mineralizing solution 
at the time of formation, that there has not been leakage from the inclusions, and that appropriate pressure corrections are made (Ingerson, 1955, p. 397-398). The inclusions are probably primary, for their distribution is limited to certain crustified layers of fluorite that are primary growth features; within these layers the inclusions are randomly distributed and are not related to visible fractures, crystal boundaries, or margins of the layers. The inclusions are regularly bounded negative crystals whose shape is controlled by the structure of the surrounding fluorite; although this is a common primary growth feature, it is not necessarily restricted to this origin.

The consistent results from successive measurements made on the same inclusion, and the generally consistent results obtained from different inclusions within the same specimen argue against significant leakage. The only measurements that deviate greatly from related measurements were on inclusion $a$, specimen $\mathrm{S}-705 \mathrm{~B}$; these are so far out of agreement with the others from the same specimen as well as with the general results from the other two specimens that leaknge is suspected.

Lacking accurate estimates on the depth of fluorspar deposition, it is not possible to apply accurate pressure corrections to the readings. However, even were the cover as much as 2,000 feet at the time of mineralization, which seems unlikely, the pressure correction according to curves given by Ingerson $(1955$, p. 396) would add only $10^{\circ}$ to each reading.

The data available are too sparse and the sample too small to be representative or to give convincing results. However, a range from $100^{\circ}$ to $150^{\circ}$ would cover all but one of the measurements made plus any likely correction for pressure, and is here considered to be a general indication of the temperatures at which the fluorite in the Northgate district was deposited.

\section{CONDITIONS OF DEPOSITION}

The deductions outlined in the preceding sections indicate a dilute aqueous mineralizing solution, predominately meteoric water containing dissolved calcium, fluorine, silica, and other minor constituents, at temperatures of $100^{\circ}$ to $150^{\circ} \mathrm{C}$, circulating through the broken rock along the late Tertiary (?) faults. The rounded fragments of wallrocks within some of the open cavities along the vein (pl. 16) indicate sufficient movement of the mineralizing solution to agitate the fragments, and the one observed stalactitic growth (pl. 17) within otherwise normally crustified vein material indicates that locally at least conditions fluctuated from below to above water table.

Two alternatives account for the agitation of wallrock fragments within the vein zone. Either the velocity and turbulence of the 
moving water was sufficient to move the fragments, or a proper combination of temperature and pressure permitted local boiling with consequent agitation. The fluctuating water-table conditions indicated by the overgrown stalactite found at the Springer pit, in combination with the temperatures of disposition of $112^{\circ}$ to $119^{\circ} \mathrm{C}$ determined for fluorite from nearby (spec. S-703, table 2), would favor the hypothesis of local boiling. Rather than growing above temporary true water table, the stalactite and its overgrowths might have grown under fluctuating vapor-liquid conditions caused by irregular or intermittent local boiling. On the other hand, this single observed stalactite may be unique in the district, and may have formed under some fortuitous combination of circumstances that cannot be evaluated.

An attempt was made to determine the general order of velocities of moving ground water required to move the wall-rock fragments. It was assumed that the velocity of a vertically directed current of water required to move a fragment of given dimensions would be about equal to the settling velocity of that same fragment in water, and thus that Stokes law would apply. The velocities so obtained would be minimum velocities required to move the fragments were no turbulence involved; as any water moving along the irregular channels represented by the vein zones at Northgate almost certainly would be turbulent, the velocities given would likely be of the proper order to cause the fragments to move.

It was assumed that the fragment under consideration was essentially spherical, had a density of 2.7 , and was immersed in water with a temperature of $100^{\circ} \mathrm{C}$ and a coefficient of viscosity of 0.028 . From Stokes law :

$$
V=\frac{2 g a^{2}\left(d_{1}-d_{2}\right)}{9 n}
$$

(where $g=$ acceleration due to gravity; $a=$ radius of the sphere; $d_{1}=$ density of the sphere; $d_{2}=$ density of the medium; and $n=$ coefficient of viscosity of the medium) it was found that a fragment 0.2 foot in diameter would be moved by a current with a velocity of 4.3 feet per second, and that a fragment 0.4 foot in diameter would be moved by a current with a velocity of 17.3 feet per second. Considering the probable effect of turbulence in lowering these minimum velocities, these figures seem well within the range that might be expected locally along an open fault zone with actively circulating ground water.

Choice between the two alternatives would depend largely on close estimates of the pressures in the zone of fluorspar deposition, and these in turn would depend on accurate estimates of the depth of 
fluorspar deposition which cannot be made (see "Depth of fluorspar deposition," p. 407).

The actual conditions along the vein zones at the time of fluorspar deposition may have been various combinations of the two alternatives outlined above. The possible fluctuating boiling conditions suggested at the Springer pit, which is on the highest part of the FluorsparGero-Penber vein zone, may have existed only locally in the uppermost parts of the vein zones where the pressures would be sufficiently low for the hot water (temperature $100^{\circ}$ to $150^{\circ} \mathrm{C}$ ) to boil. Below any such zone of irregularly fluctuating vapor-liquid phases would be a zone of circulating water, which might show a jetting effect in local more open zones and there attain velocities sufficient to agitate broken wallrock fragments as much as 4 or 5 inches in diameter.

Near-surface evaporation, whether or not by boiling, might be the main cause of saturation and precipitation of $\mathrm{CaF}_{2}$ in the fissures. The crustified veins and lack of wallrock alteration favor this means of deposition, as does the apparent small variation in solubility of $\mathrm{CaF}_{2}$ in water within the range of temperatures for which data are available (see "Composition of the mineralizing fluid," p. 408). It is not known what influence a sharp drop in pressure would have on the solubility of $\mathrm{CaF}_{2}$, but it should favor evaporation of the water and thereby the precipitation of fluorite.

\section{SOURCE OF FLUORINE}

The source of the abundant fluorine concentrated along the two vein zones in the Northgate district is a problem that cannot be answered satisfactorily from the evidence available. Whereas igneous processes and attendant hydrothermal activity provide one of the most adequate means for the concentration and precipitation of fluorine as fluorite, the Northgate district is remote from other mining districts or areas of known late Cenozoic igneous activity. The nearest known area containing igneous rocks of late Cenozoic age is near the southeast corner of North Park, about 35 miles distant, where Montagne and Barnes (1957, p. 58) describe lava flows and volcanic breccia interbedded with the North Park formation of late Miocene and early Pliocene (?) age.

Lacking direct evidence on the source of the fluorine, some rough computations were made to compare the adequacy of leaching fluorine from the country rock by circulating meteoric waters with derivation from igneous sources.

According to interpretations outlined earlier in this report the area on Pinkham Mountain containing the known fluorspar veins is probably underlain at depth by intrusive quartz monzonite. The average 542861-60-7 
fluorine content of granitic rocks, as given by Rankama and Sahama $(1950$, p. 760$)$ is $500 \mathrm{ppm}$. As the atomic weight of calcium is 40.08 and of fluorine is 19.00, approximately half of fluorite $\left(\mathrm{CaF}_{2}\right)$ is fluorine. In metric tons, which is about the same as long tons in the English system, for every million tons of fluorite there is about 500,000 tons of fluorine. To derive this quantity of fluorine from a granitic rock $\left(\frac{500,000}{0.0005}\right)$ would require complete leaching of 1 billion tons of rock. Assuming the average specific gravity of the leached rock is 2.8 , this would be about 0.357 cubic kilometer. Considering the difficulty that circulating meteoric water would have in penetrating such a volume of rock, and pervasively leaching it of all fluorine, a much larger volume would probably be required. Multiplying this by several times to account for all the fluorite in the Northgate district would increase the required volume and multiply the difficulties. The lack of wallrock alteration or other evidence of leaching at present surface levels makes this source for the fluorine even more unlikely.

To compare the adequacy of an igneous source, the often quoted figures given by Zies (1929, table 1, p. 4) for the Valley of Ten Thousand Smokes are used. According to Zies, 200,000 tons of HF was being exhaled each year at the time of his investigation; this amounts to about 190,000 tons of fluorine per year. Thus in 3 years, 570,000 tons of fluorine was exhaled, or more than enough to account for a million tons of fluorite. These quantities and rates cannot be extrapolated directly to the Northgate district, but for general adequacy, an igneous source for the fluorine seems far more logical than leaching and concentration by circulating ground water.

\section{COROLLARY HYPOTERSIS}

Assuming that the cumulative deductions in the preceding sections are virtually correct, namely that the fluorite in the Northgate district resulted from near-surface precipitation of fluorine from a primary igneous source, the disposition of other components derived from that igneous source is of interest. Volcanic fumerole gases are generally. considered to be largely of magmatic derivation, and to represent the more highly volatile magmatic constituents. Water is dominant in these gases, but other components almost always include $\mathrm{H}_{2} \mathrm{~S}$ and halogen acids. Even in an area as fluorine-rich as the Valley of Ten Thousand Smokes, Zies (1929, table 1, p. 4) found that 50 percent. more $\mathrm{H}_{2} \mathrm{~S}$ was given off than $\mathrm{HF}$.

In further developing the hypotheses on origin and environment of deposition of the fluorite at Northgate, it seems necessary to consider what may have become of a quantity of sulfur at least equal to the quantity of fluorine deposited as fluorite. This sulfur either had to pass through the zone where fluorite was being deposited without 
leaving significant trace, or it had to be deposited at depth. The very low content of sulfide minerals in association with the fluorite, and the lack of secondary products attributable to acid-sulfate alteration, which are common in near-surface zones around hot springs carrying $\mathrm{H}_{2} \mathrm{~S}$, indicates that the sulfur did not escape upward. If precipitated at depth, it must be considered that exclusive of sedimentary sulfates, the most common types of sufur-bearing minerals are metallic sulfides.

The attenuated reasoning on which these considerations are based, suggests a distinct possibility that the fluorspar deposits at Northgate, and similar deposits in other areas such as the Browns Canyon and Poncha Springs districts, Colorado (Cox, 1945), may be nearsurface manifestations of a hydrothermal system from which valuable metals may have been deposited as sulfides at depth. Whether such deposits would belong to "mesothermal" or "epithermal" types is difficult to determine, and probably depends on the particular combination of geologic conditions that existed during mineralization in each given area.

The evidence available is insufficient to warrant further exploration into details of this possible deep mineralization. Too many of the postulates leading to this deduction need further study and corroboration. In view of the increasing numbers of papers dealing with the origin, composition, and environment of deposition of oreforming solutions that have appeared in recent years, it seems likely that sufficient physical-chemical criteria will soon be established to permit testing of these hypotheses more critically, and perhaps to permit establishing limits within which any buried ore deposits might occur.

\section{SUGGESTIONS FOR PROSPECTING}

Commercial-grade fluorspar in the Northgate district seems limited to the late Tertiary (?) faults. The Fluorspar-Gero-Penber and Fluorine-Camp Creek fault zones on Pinkham Mountain have produced all the fluorspar to date, and the largest remaining reserves probably occur along them.

Exploration at depth beneath the known ore bodies is an obvious program to find additional reserves, and probably will result in the discovery of a large quantity of fluorspar. Both Ozark-Mahoning Co. and Aluminum Company of America were actively engaged in diamond drilling and underground exploration below known ore bodies when this report was being prepared.

The best opportunities for developing new ore bodies at or near the surface seem to be along the Fluorine-Camp Creek vein zone. Geologically there is no reason why fluorspar with widths and grade comparable to those exposed in Ozark-Mahoning Co. opencuts should not occur along the northwestern part of the vein zone where it tra- 
verses intrusive quartz monzonite or quartz monzonite gneiss. Fluorspar of minable grade and thickness is exposed along the western branch fault in the Camp Creek mine and in some trenches about 800 feet southeast of the Camp Creek shaft, and a favorable showing of fluorspar in broken intrusive quartz monzonite is exposed at one place near the eastern branch fault (pl. 15). Ozark-Mahoning Co. has produced fluorspar from opencuts extending to the northwestern limit of their properties, about 2,700 feet southeast of the Camp Creek shaft. The intervening segments of the fault zone are largely covered by a thick mantle of surficial debris, and surface indications of fluorspar are negligible. It would seem, however, that all of the areas along the fault zone where favorable granitic rocks constitute the walls are worthy of testing. The vicinity where the fault zone branches probably is well broken and thus is favorable for the occurrence of fluorspar. The eastern branch fault has been virtually untested, although it appears to have intrusive quartz monzonite or quartz monzonite gneiss on at least one wall for about 1,500 feet northwest of the fault junction.

The Fluorine-Camp Creek vein zone extending southeastward from the area shown on plate 15 follows a heavily wooded ravine for about 1,500 feet before it crosses a low knoll of intrusive quartz monzonite and again can be traced with fair confidence. About 2,000 feet southeast of the area shown on plate 15, an outcrop of fault breccia about 10 feet in diameter contains an estimated 30 to 40 percent fluorspar. This exposure is about 600 feet lower in altitude than the original outcrop of the vein zone near the old Baker pit. It would thus seem that the whole trend of the Fluorine-Camp Creek vein zone southeast of the Fluorine mine nearly to the bottom of Lawrence Creek valley is worthy of prospecting, and the difference in altitude between known exposures of fluorspar should encourage deep exploration beneath the ore bodies now exposed on Pinkham Mountain.

Favorable showings of fluorspar on the east vein of the FluorsparGero-Penber vein zone have been exposed in trenches and bulldozer cuts for more than 800 feet north of the Springer pit (pl. 14), and traces of fluorspar have been uncovered in bulldozer cuts along the trend of the east vein for 2,000 feet or more north of the Springer pit. The west vein has not been exposed either at the surface or underground north of the latitude of the Springer pit. Although these data are far too sparse to be conclusive, they certainly indicate that ore concentrations should extend for more than a thousand feet north of the Springer pit on the east vein, and that minable widths and grade may persist even farther north. Possibilities of ore north of present exposures along the west vein are virtually unknown. Owing to the small displacement along the Fluorspar-Gero-Penber 
vein zone, it seems possible that brecciation may die out a short distance north of known favorable indications of ore, and thus exploration and mine development in this direction should be done conservatively.

Surface indications along the trends of the two minor late Tertiary (?) faults southeast of Pinkham Mountain are not favorable for the discovery of fluorspar, although exposures are generally too poor for the ore potential to be assessed fairly. The western fault follows the bottom of a small ravine for most of its length and is not exposed. No indication of fluorspar was seen in the float and surface debris that covers the bottom of the ravine. The eastern fault crosses several low ridges of Precambrian rocks, and in a few places barren silicified fault breccia shows in outcrop or scattered float. One loosio boulder, 3 to 4 feet in diameter, of brecciated quartz monzonite gneiss cemented with crustified fluorspar was found near the southeast end of the fault, indicating that some fluorspar was deposited at least locally along it.

\section{REFERENCES CITED}

Atwood, W. W., 1940, The physiographic provinces of North America: Boston, Mass., Ginn and Co., 536 p.

Beckwith, R. H., 1938, Structure of the southwest margin of the Laramie Basin, Wyoming: Geol. Soc. America Bull., v. 49, no. 10, p. 1515-1544.

1942, Structure of the upper Laramie River valley, Colorado-Wyoming: Geol. Soc. America Bull., v. 53, p. 1491-1532.

Beekly, A. L., 1915, Geology and coal resources of North Park, Colorado: U.S. Geol. Survey Bull. 596, 121 p.

Blackwelder, Eliot, 1909, Cenozoic history of the Laramie region, Wyoming: Jour. Geology, v. 17, p. 429-444.

Burchard, E. F., 1933, Fluorspar deposits in Western United States: Am. Inst. Mining Metall. Eng. Tech. Pub. 500, 26 p.

Bush, A. L., 1951, Sources of lightweight aggregate in Colorado: Colorado Sci. Soc. Proc., v. 15, no. 8, p. 305-368.

Cobban, W. A., and Reeside, J. B., Jr., 1952, Correlation of the Cretaceous formations of the western interior of the United States: Geol. Soc. America Bull., v. 63, p. 1011-1044.

Cox, D. C., 1945, General features of Colorado fluorspar deposits: Colorado Sci. Soc. Proc., v. 14, no. 6, p. 263-285.

Cox, D. C., Benson, W. E., Steven, T. A., and Van Alstine, R. E., 1948, Fluorspar deposits of the Northgate district, Jackson County, Colorado: U.S. Geol. Survey Strategic Minerals Inv., Prelim. Rept. 3-220, 14 p.

Darton, N. H., 1904, Comparison of the stratigraphy of the Black Hills, Big Horn Mountains, and Rocky Mountain Front Range: Geol. Soc. America Bull., v. 15, p. 379-448.

Darton, N. H., Blackwelder, Eliot, and Siebanthal, C. E., 1910, Description of the Laramie-Sherman quadrangle: U.S. Geol. Survey Geol. Atlas, Folio 173, $17 \mathrm{p}$.

Goldring, E. D., 1942, An occurrence of ilsemannite: Am. Mineralogist, v. 27, no. 10, p. 717-719. 
Goldstein, August, Jr., 1946, The vermiculites and their utilization: Colorado School Mines Quart., v. 41, no. 4, 64 p.

Gorton, K. A., 1953, Geology of the Cameron Pass area, Grand, Jackson, and Larimer Counties, Colorado, in Guidebook, 8th Ann. Field Conf., Laramie Basin, Wyoming, and North Park, Colorado: Wyoming Geol. Assoc. and Wyoming Univ., p. 87-98.

Hagner, A. F., 1944, Wyoming vermiculite deposits: Wyoming Geol. Survey Bull. 34, 47 p.

Hague, Arnold, and Emmons, S. F., 1877, Descriptive geology : U.S. Geol. Explor. 40th Parallel, v. 2, 890 p.

Heaton, R. L., 1939, Contribution of Jurassic stratigraphy of Rocky Mountain region: Am. Assoc. Petroleum Geologists Bull., v. 23, no. 8, p. 1153-1177.

Ingerson, Earl, 1955, Methods and problems of geologic thermometry: Econ. Geology 50th Anniversary volume, pt. 1, p. 341-410.

Knight, S. H., 1917, Age and origin of the red beds of southeastern Wyoming [abs.] : Geol. Soc. America Bull., v. 28, p. 168.

Knight, S. H., 1953, Summary of the Cenozoic history of the Medicine Bow Mountains, Wyoming, in Guidebook, 8th Ann. Field Conf., Laramie Basin, Wyoming, and North Park, Colorado: Wyoming Geol. Assoc., and Wyoming Univ., p. 65-76.

Ladoo, R. B., 1923, Fluorspar mining in the Western States: U.S. Bur Mines Rept. Inv. 2480, 35 p.

- 1927, Fluorspar, its mining, milling, and utilization: U.S. Bur. Mines Bull. 244, 185 p.

Lee, W. T., 1922, Peneplains of the Front Range and Rocky Mountain National Park, Colorado: U.S. Geol. Survey Bull. 730-A, p. 1-17.

1927, Correlation of geologic formations between east-central Colorado, central Wyoming, and southern Montana : U.S. Geol. Survey Prof. Paper 149, $80 \mathrm{p}$.

Little, H. P., 1925, Erosion cycles in the Front Range of Colorado and their correlation: Geol. Soc. America Bull., v. 36, no. 3, p. 495-512.

Love, J. D., 1939, Geology along the southern margin of the Absaroka Range, Wyoming: Geol. Soc. America Spec. Paper no. 20, 134 p.

Lovering, T. S., 1929, Geologic history of the Front Range, Colorado: Colorado Sci. Soc. Proc., v. 12, no. 4, p. 59-111.

1930, The Granby anticline, Grand County, Colorado: U.S. Geol. Survey Bull. 822-B, p. 71-76.

Mather, K. F., 1925, Physiographic surfaces in the Front Range of northern Colorado and their equivalents on the Great Plains [abs.]: Geol. Soc. America Bull., v. 36, no. 1, p. 134-135.

McGrew, P. O., 1951, Tertiary stratigraphy and paleontology of south-central Wyoming, in Guidebook, 6th Ann. Field Conf.: Wyoming Geol. Assoc., p. 54-57.

- 1953, Tertiary deposits of southeastern Wyoming, in Guidebook, 8th Annual Field Conference, Laramie Basin, Wyoming, and North Park, Colorado: Wyoming Geol. Assoc. and Wyoming Univ., p. 61-64.

Miller, J. C., 1934, Geology of the north and south McCallum anticlines, Jackson County, Colorado, with special reference to petroleum and carbon dioxide: U.S. Geol. Survey Circ. 5, 27 p.

Montagne, John, de la, 1953, Late Tertiary normal faults along the east flank of the Park Range, Wyoming and Colorado, in Guidebook, 8th Ann. Field Conf., Laramie Basin, Wyoming, and North Park, Colorado: Wyoming Geol. Assoc. and Wyoming Univ., p. 103-105. 
Montagne, John, de la, 1957, Cenozoic structural and geomorphic history of Northern North Park and Saratoga Valley, Colorado and Wyoming, in Guidebook to the geology of North and Middle Parks basin, Colorado : Rocky Mountain Assoc. Geologists, p. 36-41.

Montagne, John, de la, and Barnes, W. C., 1957, Stratigraphy of the North Park formation in the North Park area, Colorado, in Guidebook to the geology of North and Middle Parks basin, Colorado: Rocky Mountain Assoc. Geologists, p. 55-60.

Oster, L. D., 1953, Stratigraphy of the Cloverly formation, the Thermopolis shale, and the Muddy sandstone in part of southeastern Wyoming, in Guidebook, 8th Ann. Field Conf., Laramie Basin, Wyoming, and North Park, Colorado: Wyoming Geol. Assoc. and Wyoming Univ., p. 40-46.

Phillips, A. H., and Hess, H. H., 1936, Metamorphic differentiation at contacts between serpentinite and siliceous country rocks: Am. Mineralogist, v. 21, no. 6, p. 333-362.

Pipiringos, G. N., 1953, Correlation of marine Jurassic and related rocks in the Laramie Basin, Wyoming, in Guidebook, 8th Ann. Fleld Conf. Laramie Basin, Wyoming, and North Park, Colorado: Wyoming Geol. Assoc. and Wyoming Univ., p. 34-39.

Rankama, Kalervo and Sahama, Th. G., 1950, Geochemistry, Chicago Univ. Press, 912 p.

Reeside, J. B., Jr., 1931, Supposed marine Jurassic (Sundance) in foothills of the Front Range of Colorado: Am. Assoc. Petroleum Geologists Bull., จ. 15, no. 9, p. 1095-1103.

Rocky Mountain Association of Geologists, 1957, Guidebook to the geology of North and Middle Parks basins, Colorado: Rocky Mountain Assoc. Geologists.

Seidell, Atherton, 1940, Solubilities of inorganic and metal organic compounds, 3d ed., v. 1, New York, D. Van Nostrand Co.

Sims, F. C., and Goth, J. H., Jr., 1953, McCallum field, Jackson County, Colorado, in Guidebook, 8th Ann. Field Conf., Laramie Basin, Wyoming, and North Park, Colorado: Wyoming Geol. Assoc. and Wyoming Univ., p. 156-158.

Steven, T. A., 1953, Geology of the Northgate fluorspar district, Colorado, in Guidebook, 8th Ann. Field Conf., Laramie Basin, Wyoming, and North Park, Colorado: Wyoming Geol. Assoc. and Wyoming Univ., p. 106-110.

1954, Geology of the Northgate fluorspar district, Colorado: U.S. Geol. Survey Minerals Inv., Field Studies Map, MF 13.

1956, Cenozoic geomorphic history of the Medicine Bow Mountains near the Northgate fluorspar district, Colorado: Colorado Sci. Soc. Proc., $\nabla$. 17, no. 2, p. 35-55.

1957a, Metamorphism and the origin of granitic rocks in the Northgate district, Colorado: U.S. Geol. Survey Prof. Paper 274-M, p. 335-375.

1957b, Sentinal Mountain-Dean Peak faulted anticline, North Park, Colorado, in Guidebook to the geology of North and Middle Parks basin, Colorado: Rocky Mountain Assoc. Geologists, p. 82-84.

Thomas, H. D., 1934, Phosphoria and Dinwoody tongues in lower Chugwater of central and southeastern Wyoming : Am. Assoc. Petroleum Geologists Bull., v. 18, no. 12, p. 1655-1697.

Van Tuyl, F. M., and Lovering, T. S., 1935, Physiographic development of the Front Range: Geol. Soc. America Bull., v. 46, p. 1291-1350.

Waagé, K. M., 1955, Dakota group in northern Front Range foothills, Colorado: U.S. Geol. Survey Prof. Paper 274-B, p. 15-51. 
Warne, J. D., 1947, Northgate fluorspar, Jackson County, Colorado: U.S. Bur. Mines Rept. Inv. 4106, $23 \mathrm{p}$.

Welsh, J. E., 1953,. Geology of the Sheep Mountain-Delaney Butte area, North Park, Colorado, in Guidebook, 8th Ann. Field Conf., Laramie Basin, Wyoming, and .North Park, Colorado: Wyoming Geol. Assoc. and Wyoming Univ., p. 99-100.

White, D. E., 1955, Thermal springs and epithermal ore deposits : Econ. Geology, 50th Anniversary volume, pt. 1, p. 99-154.

Wyoming Geological Association, 1953, Guidebook, 8th Ann. Field Conf., Laramie Basin, Wyoming, and North Park, Colorado: Wyoming Geol. Assoc. and Wyoming Univ.

York, H. F., 1957, Geology of the Elk Mountain anticline, North Park, Colorado, in Guidebook to the geology of North and Middle Parks basin, Colorado: Rocky Mountain Assoc. Geologists, p. 74-81.

Zies, E. G., 1929, The Valley of Ten Thousand Smokes, I. The fumerolic incrustations and their bearing on ore deposition : Natl. Geog. Soc., Contributed Tech. Papers, Katmai Ser., v. 1, n. 4, p. 1-61. 


\section{INDEX}

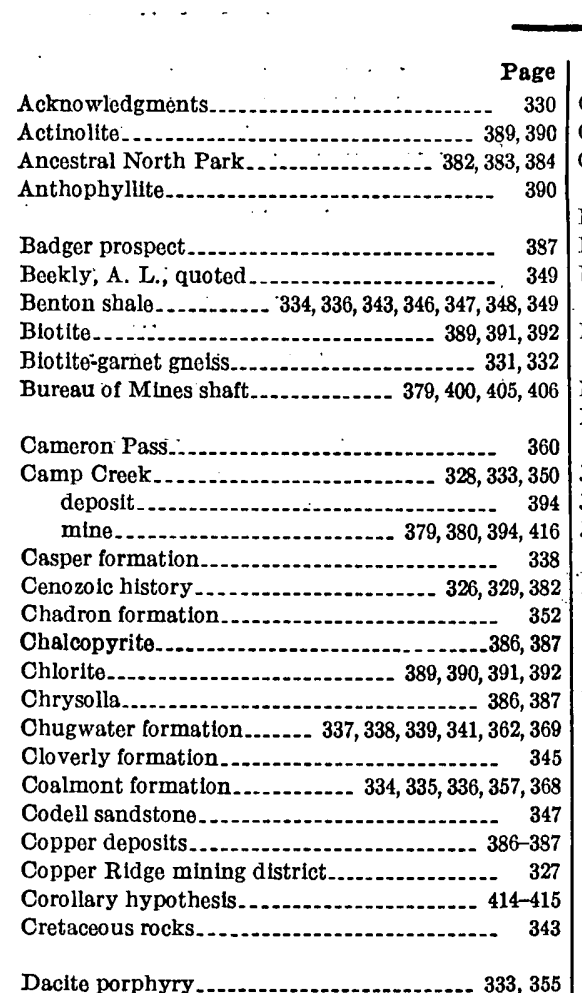

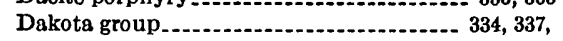
$342,343,344,345,346,347,360,362,365$

Dakota-Lakota.

Dean Peak

Dikes, distribution

Drainage.

Dynamic metamorphism

Dynamothermal metamorphism

Entrada sandstone

Eocene epoch.

Erosion surfaces. $382,383,385$

Faults, of late Tertiary age 375-376, 411 of probable Laramide age.. south and southwest of Sentinal Moun-

tain. 366-367

Fluorspar, defined. deposits...... 325, 327, 329, 376, 386, 390, 395, 396 grade of ore.......................... 399, 400 Fluorspar mine _- 376, 377, 393, 394, 395, 402, 406, 416 ore produced ............................. 394, 395 Forelle(?) limestone................. 335, 337, 338, 369 Fossils. 340,347
Garnets.... 380 Gero mine ....................... 376, 377, 393, 394, 402 Government Creek..................... 328, 338, 364

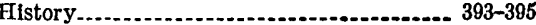
Hornblende-biotite gneiss...................... 332, 401 Eornblende gnelss............................ 331, 401

Independence Mountain fault............. 357, 359, $360,362,365,366,367,368,369,370,390,396$ Industries in region............................ 328 Intrusive quartz monzonite...... $333,355,356,397,401$. Jackson County............................ 326, 327 Jelm formation............................. 339, 341

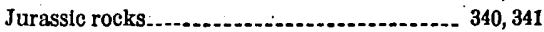

Kings Canyon................................. 328

Kings Canyon mine......................... 387 Kramer mill............... 394

Laramide orogeny................ 335, 354, 357, 359, 370 Laramte Basin ........................... 335, 338, 359

Laramle Mountains........................... 352 Lawrence Creek................................. 350, 372

Lytle formation. . .............................. 345

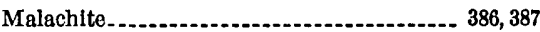

Medícine Bow arch................ 359

Mediclne Bow Mountains.................... 326, $327,328,333,344,355,357,359,367,385$ Medicine Bow surface................... 378, 385, 407 Mesozoic rocks.......................... 334, 336, 337 Metasomatism........................ 331, 332, 389 Mlddle Park .................................. $\quad 359$ Middle Park formation..................... 357 Minerallzing fluld, composition.............. 408-400 Mlocene deformation................ 371 Miocene and Pllocene (?) rocks........... 334, 336, 352 Molybdenite................ 387 Morrison formation......... 337, 340, 341, 342, 343, 362 Mowry shale............................. 343, 347, 340 Muddy sandstone............................. 345 Mylonite gneiss................................ 332

Nlobrara formation........... 334, 336, 347, 348, 349, 350 North Park.................................. 326 $327,328,333,350,352,357,358,359,366,367,384$ North Park formation............ 336, 352, 353, 372, 384 North Platte River.................... 327, 366, 372, 384 North Sand Hills............................... 354 Nugget-Navajo sequenco....................... 341

Old Baker Pit_........... 379, 393, 394, 403, 405, 406, 416 Oligocene rocks....................... 334, 336, 350, 383 $327,357,359$ 
Pegmatite.

Penber mine....... 376, 377, 393, 394, 395, 397, 402, 406

Permian rocks.......................... 334, 335, 337, 338

Pierre shale......... 334, 335, 336, 350

Pinkham Creek. ............ 328

Pinkham Mountain..................... 333, 355, 356

Pleistocene rejuvenation.................. 386

Pliocene deformation....................... 372, 376

Post-Laramide deformation.................. 371

Precambrian rocks.......... 326, 329, 330, 337, 351, 362

Quaintance No. 1 deposit.

387

Quartz monzonite gneiss........ 331, 332, 333, 397, 401

Quaternary rocks............................... 334

Resort deposit........... 389

Rheomorphism ..................... 332, 333, 355

Riggs (Fourney) deposit....................... 389

Saratoga-Encampment Valley.............. 352, 353

Saratoge basin.................. 384

Satanka(?) shale

Sentinal Mountain............... 338, 343, 360, 361, 362

Serpentinite........................ 389, 390, 391,392

Source of fluorine. . .

South Platte formation. ...................... 345

Springer pit............. 416

Stratigraphic sequence..................... 336

Structures, gneiss complex................ 354

intrusive rocks.

Sundance formation............ 337, 340, 341, 342, 366

Surficial deposits. ................. 354

Suggestlons for prospecting _........... 416-417

Tectonic map.

Tertiary rocks. . ........... 334, 336, 350

Thermopolis shale

Tremolite . . . .................... 389, 390, 391,392

Ultramaflc rocks......... $331,389,390$

Valley of Ten Thousand Smokes............. 414

Vermiculite deposits................. 386, 387, 389, 390

Vertical range of fluorspar deposits. . . ..... 405-407

Village Belle mine._............... 387

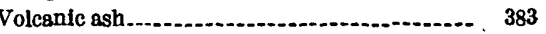

Watson Mountain. ........................ 352, 368

Watson Mountain, fault zone................. 369

White River formation ................... 336, 350 , $351,353,368,370,371,378,380,382,401$ 